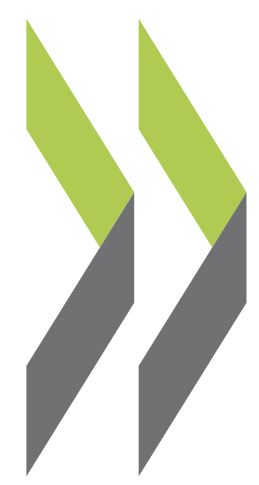

OECD Trade and Environment Working Papers 2019/01

Trends in policy indicators on trade and environment

\title{
Grégoire Garsous
}




\section{OECD TRADE AND ENVIRONMENT WORKING PAPERS}

This paper is published under the responsibility of the Secretary-General of the OECD. The opinions expressed and the arguments employed herein do not necessarily reflect the official views of OECD countries.

The publication of this document has been authorised by Ken Ash, Director of the Trade and Agriculture Directorate.

This document and any map included herein are without prejudice to the status of or sovereignty over any territory, to the delimitation of international frontiers and boundaries and to the name of any territory, city or area.

The statistical data for Israel are supplied by and under the responsibility of the relevant Israeli authorities. The use of such data by the OECD is without prejudice to the status of the Golan Heights, East Jerusalem and Israeli settlements in the West Bank under the terms of international law.

This document has been declassified on the responsibility of the Joint Working Party on Trade and the Environment under the OECD reference number COM/TAD/ENV/JWPTE(2018)2/FINAL.

Comments on the series are welcome and should be sent to tad.contact@oecd.org.

You can copy, download or print OECD content for your own use, and you can include excerpts from OECD publications, databases and multimedia products in your own documents, presentations, blogs, websites and teaching materials, provided that suitable acknowledgment of OECD as source and copyright owner is given. All requests for commercial use and translation rights should be submitted to rights@oecd.org. 


\title{
TRENDS IN POLICY INDICATORS ON TRADE AND ENVIRONMENT
}

\author{
Grégoire Garsous, OECD
}

Addressing the relationship between domestic environmental regulations and international trade policies is essential to better understand the need for consistency and complementarity between these areas. The set of trade and environment indicators developed by the OECD aims to provide insights on this relationship by shedding light on topical debates regarding the interactions between trade and environmental policies. Issues covered include: carbon emissions embodied in trade; embodied raw materials in trade; the volume of trade in environmentally-related goods; tariffs on environmentally-related goods; support measures for fossil fuels; enabling policy and regulatory environment for renewable energy; the volume of trade in waste and scrap; and nutrient balances of exported grains. Although initial insights are provided for these indicators, no detailed analyses is developed at this stage. Rather, these indicators are building blocks to analyse, for instance, the determinants of identified trends or to allow for a better understanding of the issues at hand. Possible avenues for further policy-relevant investigations using the indicators are identified and discussed for each topic covered.

Key words: Trade policies, environmental regulations

JEL codes: F14, F18, F64, Q17, Q56, Q58.

\section{Acknowledgements}

This report was prepared by Grégoire Garsous form the Trade and Agriculture Directorate with the support of Hélène Blake, Mark Matteo, Aleksandra Paciorek, and Andres Sanabria. The author would like to thank Ken Ash, Rachel Bae, Peter Borkey, Miguel Cardenas Rodriguez, Assia Elgouacem, Guillaume Gruère, Santiago Guerrero, Joaquim Guilhoto, Ivan Hascic, Franck Jésus, Nick Johnstone, Jane Korinek, Myriam Linster, Jehan Sauvage, Dirk Rottgers, Shunta Yamaguchi, and Nori Yamano for their comments and help in developing this study. The author also wishes to thank the members of the OECD Joint Working Party on Trade and Environment for their valuable feedback and direction received in developing and finalising this study. Finally, the author thanks Laëtitia Christophe and Michèle Patterson for preparing this document for publication. 


\section{Table of contents}

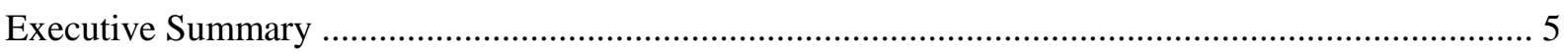

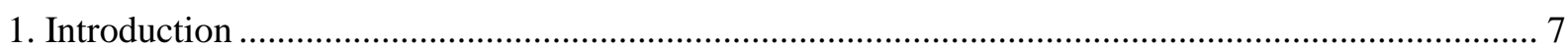

2. Carbon emissions embodied in trade

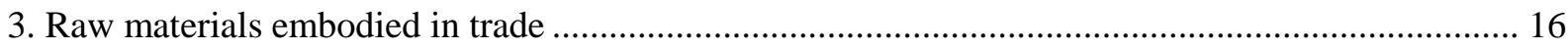

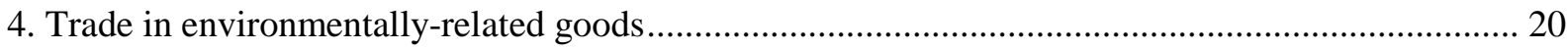

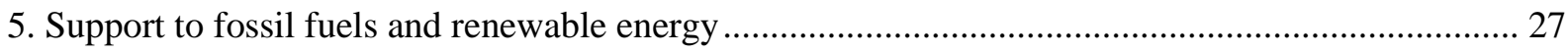

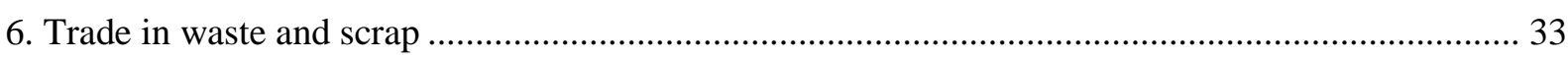

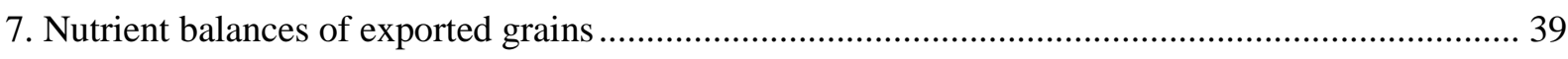

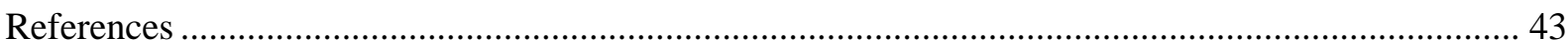

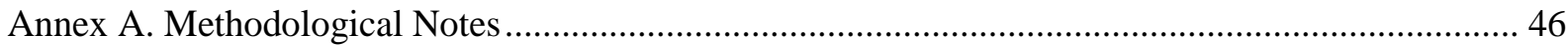

\section{Tables}

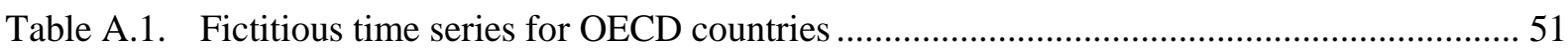

Table A.2. Table of equivalences between 2016 ICIO codes and ISIC Rev. 3 categories .................... 53

Table A.3. Countries and economies covered by the indicators on carbon emissions embodied

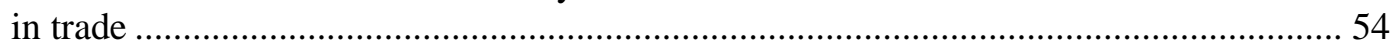

\section{Figures}

Figure 1. Global carbon emissions and emissions embodied in trade ............................................. 11

Figure 2. Global imports versus global emissions embodied in trade ............................................ 11

Figure 3. Carbon emissions embodied in bilateral trade flows in 2011 ......................................... 12

Figure 4. Imported emissions in OECD countries (1995-2011) ...................................................... 13

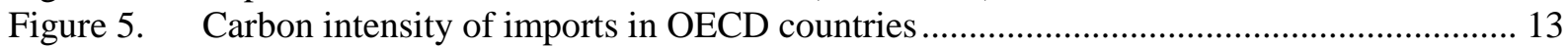

Figure 6. Imported emissions in OECD countries by scale, composition and technique effects ..... 14

Figure 7. Decomposing the increase of imported emissions into the scale, composition and technique effects ................................................................................................ 15

Figure 8. Imported emissions in OECD countries using the Equal Carbon Intensity (ECI)

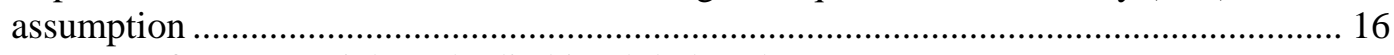

Figure 9. Amount of raw materials embodied in global trade...................................................... 18

Figure 10. Top 20 importers of raw materials (by share of global trade in raw materials) ................ 19

Figure 11. Top 20 exporters of raw materials (by share of global trade in raw materials) ................ 19 
Figure 12. Renewable Energy Plants (REP) is the single largest exported environmentallyrelated goods medium

Figure 13. The OECD's share in global trade in environmentally related goods has been decreasing, 2003-2016

Figure 14. There is a considerable difference in EGs' tariffs between the OECD countries and countries outside the OECD area amid signs of decreasing gap...

Figure 15. High-tariff outliers are applied in both OECD countries and countries outside the

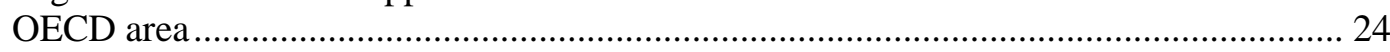

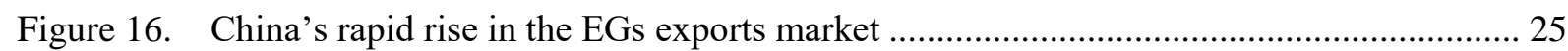

Figure 17. China is the main driver of EGs exports from countries outside the OECD area............. 25

Figure 18. China's renewable energy plant exports is larger than the total EGs exports of seven countries

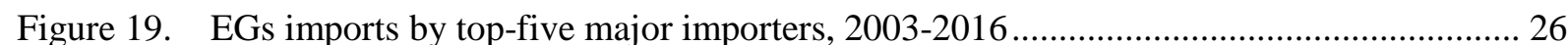

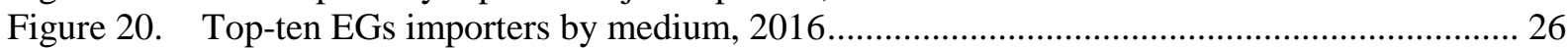

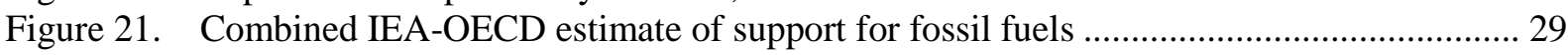

Figure 22. Combined IEA-OECD estimate of support by type of fuel ............................................ 30

Figure 23. Enabling policy and regulatory environment for renewable energy by type of policies and areas (2015).....

Figure 24. Enabling policy and regulatory framework for renewable energy and net exports of renewable energy plants equipment (2015) ................................................................ 32

Figure 25. Support to fossil fuels and exports of net renewable energy plants equipment (2015) .... 33

Figure 26. Value of global trade in waste and scrap in USD billion (2003-2016) ............................ 35

Figure 27. Weight of global trade in waste and scrap in million tonnes (2003-2016) ....................... 36

Figure 28. Top 20 exporters of waste and scrap (by share of global WS trade in 2016) ................... 37

Figure 29. Top 20 importers of waste and scrap (by share of global WS trade in 2016) .................. 37

Figure 30. The diversification of trade in waste and scrap exports destinations ............................... 38

Figure 31. The share of municipal solid waste landfilled as a driver of trade in waste and scrap (2016)

Figure 32. Nutrient balances of exported grains from OECD countries (2006-2014) ...................... 41

Figure 33. Nutrient balances and volume of exported grains as shares of domestic nutrient balance and share of production volume - 2014

Figure A.1. Decomposing the increase of imported emission into scale, composition and technique effects

Figure A.2. Relationships between classification codes in different HS versions ................................59

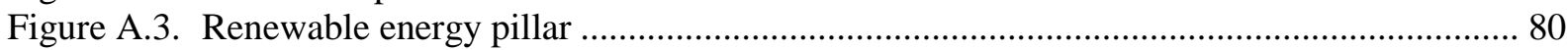

Figure A.4. Relationships between classification codes in different HS versions .............................. 84

Figure A.5. Main elements in the nitrogen and phosphorus balance calculations .............................. 90

Box

Box 1.1. China's rise in international markets for environmentally-related goods.................. 25 


\section{Executive Summary}

International trade and trade policy reforms face strong headwinds at a time when a range of environmental issues are increasingly acute and call for strong and co-ordinated international action (OECD, 2012). Addressing the relationship between trade and environment policies has become essential to better understand the relationship between domestic environmental regulations and international trade policies, as well as the need for consistency and complementarity between these two areas.

The set of trade and environment indicators (henceforth T\&E indicators) developed by the OECD aims to provide insights on these questions. Although the present report does not seek to comprehensively cover the diverse and complex interlinkages through which trade can affect the environment and vice-versa, an initial set of indicators was developed to cover a selected list of issues based on available information and data. These indicators provide a relevant source of information to shed light on several topical debates regarding the interactions between trade and environmental policies.

The T\&E indicators show that between 2003 and 2016 international trade in environmentally-related goods (EGs) more than doubled - from USD 531.10 billion to USD 1261.24 billion - increasing its share in global trade from $7.2 \%$ to $8.1 \% .^{1}$ This robust growth was mostly driven by three categories of EGs: (i) components of renewable energy plants; (ii) equipment for wastewater management and treatment; and (iii) management of solid and hazardous waste and recycling systems.

A growing body of literature suggests this growth is partly the result of environmental policies which create markets for environmental goods and services, and which in turn improve the competitiveness of local firms operating in these industries. For instance, the more stringent the regulation of the municipal solid waste management sector, the stronger the trade comparative advantage in related environmental goods, lending support to the argument that a demand for these goods is created as a result of stricter environmental standards (Sauvage, 2014).

Preliminary analysis of T\&E indicators confirm these results, and suggests that a strong policy and regulatory environment for the deployment of renewable energy is associated with an increase in the net exports of equipment for renewable energy plants. Conversely, countries that spend a larger share of their GDP to support fossil fuels seem to harm the competitiveness of their domestic renewable industry. This effect is particularly strong in countries outside the OECD area.

Trends in T\&E indicators that measure carbon emissions embodied in trade suggest that a subset of countries specialise in carbon intensive activities in ways that are consistent with the existence of pollution havens. The types of emissions they produce are sometimes disproportional to their contribution to global trade; between 1995 and 2011, emissions exported from countries outside the OECD area to OECD countries increased by $91 \%$, as more carbon intensive goods were produced in the former and shipped to the latter.

1 The environmentally related goods refer here to the Combined List of Environmental Goods (CLEG) as used in Sauvage (2014), which provides the Harmonized System 6-digit level codes of 248 products. There is no consensus on which traded goods should be deemed "environmental" and relying on this list is a practical approach to overcome the challenges to defining an internationally agreed list of environmental goods. See methodological annex of the indicator on trade in environmentally related goods for a full discussion. 
Although these goods were produced using processes with a declining level of carbon emissions due to substantial improvements in technology, overall the industrial processes in OECD countries remain cleaner.

The T\&E indicators also show that the volume of raw materials embodied in goods shipped across borders increased by $146 \%$ between 1990 and 2010, accounting for $36 \%$ of total material extraction. This trend is partly accounted for by rapid urbanisation and improvements in living standards, particularly in Asia and some parts of Europe. As a result, strong demand for cement and steel have translated into high growth of trade in nonmetallic minerals (198\%) and metal ores $(162 \%)$.

Regarding the trade of agricultural products, $T \& E$ indicators show that nutrient surpluses - of nitrogen and phosphorous - for a subset of exported grains from a selected sample of OECD countries declined between 2006 and 2014. And this happened despite an increase in volume of exported grains over the same period, suggesting that the response to growing global demand for these grains has been decoupled from the nutrient surpluses they may induce. However, some countries export grains that disproportionately contribute to both nitrogen and phosphorous nutrient surpluses of total production as responding to rising global demand leads some countries to increase nutrient-related environmental pressure.

Finally, T\&E indicators measuring the volume of trade in waste and scrap (WS) increased by $181 \%$ in value and $47 \%$ in weight between 2003 and 2016. Trade in WS involves a limited number of countries, with the top 20 exporters and importers accounting for $79 \%$ of total exports and $84 \%$ of total imports respectively.

These preliminary results illustrate the benefits of strengthening the coherence and complementarity between trade and environment policies at the national and international levels. For example, if appropriate domestic environmental policies are in place (e.g. correctly pricing exhaustible environmental resources), opening markets to trade in environmental goods could improve access to new technologies, which would then make local production processes more efficient by reducing the use of inputs such as energy, water, and other environmentally harmful substances. Similarly, trade and investment liberalisation could provide firms with incentives to adopt more stringent environmental standards. Indeed, as a country becomes increasingly integrated within the world economy, its export sector is more exposed to environmental requirements imposed by leading importers. This could stimulate the use of cleaner production processes and technologies along supply chains.

However, differentiated environmental standards across countries can impose higher or lower compliance costs on firms, which in turn could affect their competitiveness on international markets. Some empirical analyses suggest this is already the case for a limited number of energy-intensive industries. Differentiated environmental regulations may also provide industries with incentives to relocate some stages of production to jurisdictions with environmental policies that are more lax or to source inputs from them. This carries the risk of creating pollution havens. Dialogue and concerted actions based on international co-operation can minimise (and even avoid) such adverse effects. 


\section{Introduction}

\section{Data is key for empirical analysis}

Since 1991, the OECD has spearheaded efforts to improve the compatibility of trade and environmental policies. The lack of data, however, has been a hindrance to empirical analysis and has made it difficult to develop strong policy-oriented messages. Good data not only ensures solid empirical evidence, but also forms the basis of clear policy recommendations and to monitor the progress being made. ${ }^{2}$

The creation of a set of indicators to monitor country progress in developing complementary trade and environment policies addresses this gap. These indicators could serve to identify policy priorities that would enable the OECD and policy makers to prioritise their efforts where most needed.

\section{Objectives and desired outcomes}

The set of indicators presented in this report aims to contribute to three overarching objectives:

- Enable policy makers to track their progress in improving the compatibility between trade and environmental policies.

- Identify areas of potential conflict between trade and environmental policies so as to help determine future policy priorities and to focus potentially scarce governmental resources where they are most needed.

- Improve the precision of OECD work in the area of trade and the environment through quantitative analysis.

It is beyond the reach of this work to comprehensively cover the diverse and complex interlinkages through which trade can affect the environment and vice-versa. This report presents an initial set of indicators that cover carefully selected issues based on available information and data.

These indicators are metrics providing an incomplete but relevant source of information to shed light on some of the topical debates on the interactions between trade and environmental policies. As such, they do not provide definitive answers but enable new empirical analyses to be undertaken on these issues. In other words, the indicators form a sound base for analytical work but do not identify the main drivers of trends. Rather, they have been designed so that they can be introduced in econometric models that explicitly aims at decomposing the main factors that explain variations across countries and time.

Country coverage depends on data availability, although universal coverage is achieved for most indicators. OECD countries are covered in all but two indicators. ${ }^{3}$ The coverage of countries outside the OECD area is either wide (covering 40 of the most relevant countries)

2 On the trade side, the Services Trade Restrictiveness Index (STRI) and the Trade Facilitation Indicators (TFIs) are now used extensively to answer empirical, policy-relevant questions, and to monitor the progress of countries toward a fair and open trading system. On the environmental side, several sets of indicators enable the monitoring of environmental performance and the integration of environmental concerns in economic and sectoral policies. For example, the OECD's Green Growth Indicators enable the assessment and comparison of progress by countries with respect to key dimensions of green growth.

3 These are: (i) the indicator on enabling policy and regulatory environment for renewable energy; and (ii) the indicator on nutrient balances of exported grains. 
or quasi-universal, which allows comparison between the situation of OECD countries and the rest of the world. For indicators that do not achieve a universal coverage, a detailed list of covered countries is provided in the associated methodological note (Part 2 of this report).

This report presents preliminary descriptive analysis of a set of ten policy indicators on trade and the environment. Although initial insights are provided for several indicators, the OECD does not seek to develop detailed analyses at this stage. Rather, the indicators are viewed as building blocks to analyse, for instance, the determinants of identified trends or to allow for a better understanding of the issues at hand.

Possible avenues for further policy-relevant investigations using the indicators have been identified and include the following.

The indicators on embodied carbon emissions in trade would allow analysts to revisit the pollution havens issue. If introduced into a gravity model, these indicators would help estimate the effect of environmental policy stringency on actual $\mathrm{CO}_{2}$ emissions embodied in imports, rather than on the imports themselves, which have been the focus of the existing literature. This could also help determine if these effects imply the replacement of domestic production in a given country by an increased carbon-intensive process in another country. The results would shed light on the magnitude of the pollution havens issues and help clarify whether this is a first-order issue for international trade that requires specific policy intervention.

Gravity models could be used to address the drivers of the indicator on raw materials embodied in trade or the indicator on trade in waste and scrap. Carrying out such a quantitative exercise would allow for more insights on how differences between countries in related environmental policy affect the patterns of trade in embodied raw materials, and in waste and scrap.

The indicator on enabling policy and regulatory environment for renewable energy is a potential driver of the indicator on trade in environmentally-related goods. Introducing these indicators into econometric analyses would allow for the estimation of the extent to which a strong policy and regulatory environment for renewables can create a competitive advantage in the industries of goods related to renewable energy power generation. Incentives for firms and households to acquire new equipment and techniques in the domain of renewable energy could generate higher demand for associated environmentally related goods and services that could result in more exports. ${ }^{4}$ Conversely, the indicator on support measures for fossil fuels and the indicator on tariffs applied to environmentallyrelated goods are potential hurdles to such outcomes. Estimating quantitatively their (potentially negative) influence on the development of alternative sources of energy through international trade would shed new light on the debate around the distortive effects of such measures.

Finally, using the indicator on the nutrient balance of exported grains and a trade-openness index, one could analyse whether trade liberalisation led the basket of grains dedicated to exports to differ from the basket of grains for domestic consumption, resulting in different nutrient balances and potentially different environmental pressure. This would inform

4 This effect is known as the "home-market" effect (Krugman, 1980). It predicts that if goods are differentiated and there is free entry into markets, an increase in the size of the home market of a good leads to an increase in the net exports of this same good. 
policy makers on the unintended consequences of trade liberalisation and, if necessary, help shape appropriate domestic policy responses.

\section{Carbon emissions embodied in trade}

\section{Definitions of the indicators ${ }^{5}$}

\section{The amount of carbon emissions embodied in trade}

The amount of carbon emissions from fossil fuel combustion embodied in imports and exports in mega tonnes of $\mathrm{CO}_{2}\left(\mathrm{MtCO}_{2}\right)$ for 63 countries (and the Rest of the world) and 34 industries between 1995 and $2011 .^{6}$

\section{Carbon emissions embodied in trade under the Equal Carbon Intensity (ECI) assumption}

The hypothetical amount of carbon emissions from fossil fuel combustion embodied in imports if imported goods were produced with a carbon intensity (i.e. emissions factors) equal to that of the importing country at a given time - the Equal Carbon Intensity (ECI) assumption.

\section{Scale, composition and technique effects of imported carbon emissions}

The estimated growth in imported emissions of a country derived from: (i) changes in the volume of imports; (ii) changes in the composition of imports; and (iii) changes in the carbon intensity in countries where emissions were generated.

\section{State of progress of the indicators}

The development of the three indicators on carbon emissions embodied in trade is well advanced. Policy relevant analyses based on these indicators are provided below. Relying on econometrics, further analyses could estimate the effect of environmental policy stringency on actual carbon emissions embodied in imports, rather than on the imports themselves, which are the focus of the existing literature. An update of this indicator could expand the time coverage up to the year 2015.

\section{Main messages}

Trends in carbon emissions embodied in trade seem to suggest that a subset of countries specialise in economic activities that are consistent with the existence of pollution havens. ${ }^{7}$ That is, more carbon intensive goods are produced in countries outside the OECD area and shipped to OECD countries.

5 Sources for these indicators are Wiebe and Yamano (2016) and the International Energy Agency (2018). See Annex A for full details.

6 See Annex A for a complete list of countries and industries covered by this indicator.

7 The preliminary analysis presented here suggests the existence of pollution havens but does not prove it. Pollution haven effects imply that the replacement of domestic production in a given country by a more carbon-intensive process in another country is caused by cross-country differences in environmental policy stringency, a condition these indicators does not capture. 
Although these imported goods are produced using processes with lower carbon emissions as a result of improvements in technology, industrial processes in countries outside the OECD area remain more polluting than in OECD countries.

The opposite is true for trade among advanced OECD countries: a larger amount of emissions would have been generated had these goods been manufactured in the countries they are imported to, which suggests that intra-OECD trade allows goods to be produced where carbon intensity of industries - as measured by the ratio of amount of emissions per unit of output - is lower.

These observations are in line with studies carrying out a similar exercise (FernandezAmador, François and Romberger, 2016) and complement results of empirical analyses that provide evidence on the pollution haven effects for a limited number of energyintensive industries (Kozluk and Timiliotis, 2016; Garsous and Kozluk, 2017).

\section{Policy context}

Because of the increasingly fragmented nature of production processes across countries, domestic $\mathrm{CO}_{2}$ emissions are sometimes generated for the production of goods consumed in other countries. Such global interconnectedness carries the risk that uneven domestic policies may lead to pollution havens, whereby countries with lax environmental regulations progressively specialise in pollution-intensive goods that are exported to other countries with more stringent environmental policies. Examining carbon emissions embodied in trade can help improve the understanding of the magnitude of this effect. This is especially relevant in the international context of the Paris Agreement that includes a pledge to unilaterally implement nationally determined contributions (NDCs). ${ }^{8}$

The three indicators developed by the OECD are designed to help increase the understanding of pollution leakages, which arise when a tightening of environmental regulation deters domestic production and stimulates imports of pollution-intensive goods (Taylor, 2005). The first indicator is useful to determine whether the relocation of the domestic production is caused by cross-country differences in environmental policy stringency. The second indicator gives a sense of whether such a relocation occurs in more carbon-intensive countries. The third indicator captures whether the composition of imported goods follows the pattern of specialisation predicted by pollution leakages.

\section{Main trends}

\section{Carbon emissions in trade reflect global interconnectedness}

Since 1995, carbon emissions embodied in trade have been increasing both in absolute value and as a share of global emissions (Figure 1). However, the volume of global trade has grown more rapidly than carbon emissions embodied in it (Figure 2), probably reflecting general trends of relative decoupling between economic growth and $\mathrm{CO}_{2}$ emissions (OECD, 2017). In 2011, carbon emissions embodied in trade accounted for $21 \%$ of global emissions. While this is significant, it also points out that the bulk of carbon emissions are generated domestically for the production of goods and services that are eventually consumed domestically.

8 Nationally determined contributions (NDCs) are at the heart of the Paris Agreement and the achievement of its long-term goals. NDCs embody efforts by each country to reduce national emissions and adapt to climate change (see https://unfccc.int/process/the-paris-agreement/nationallydetermined-contributions). 
Figure 1. Global carbon emissions and emissions embodied in trade

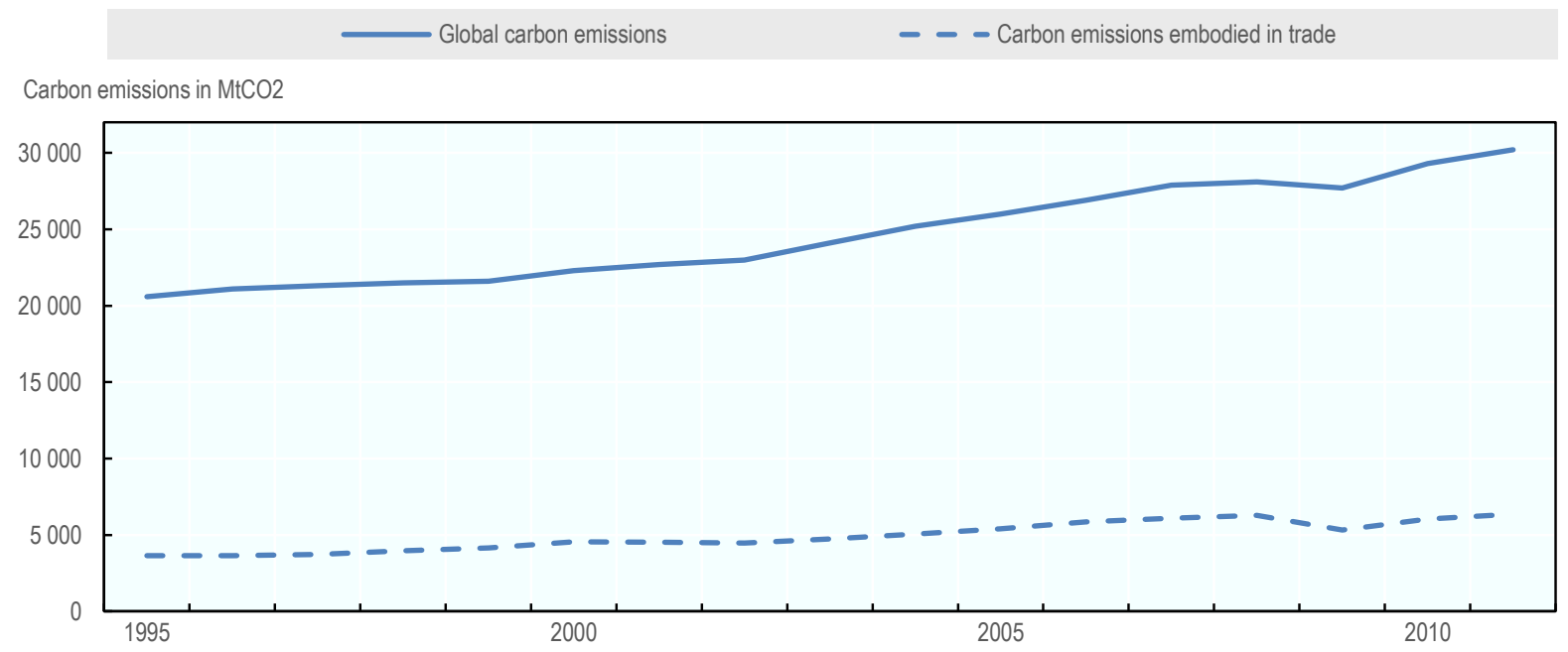

Source: Authors' elaboration based on Wiebe and Yamano (2016) using the 2016 OECD Inter-Country Input-Output model and emissions from fuel combustion in International Energy Agency (2018).

Figure 2. Global imports versus global emissions embodied in trade

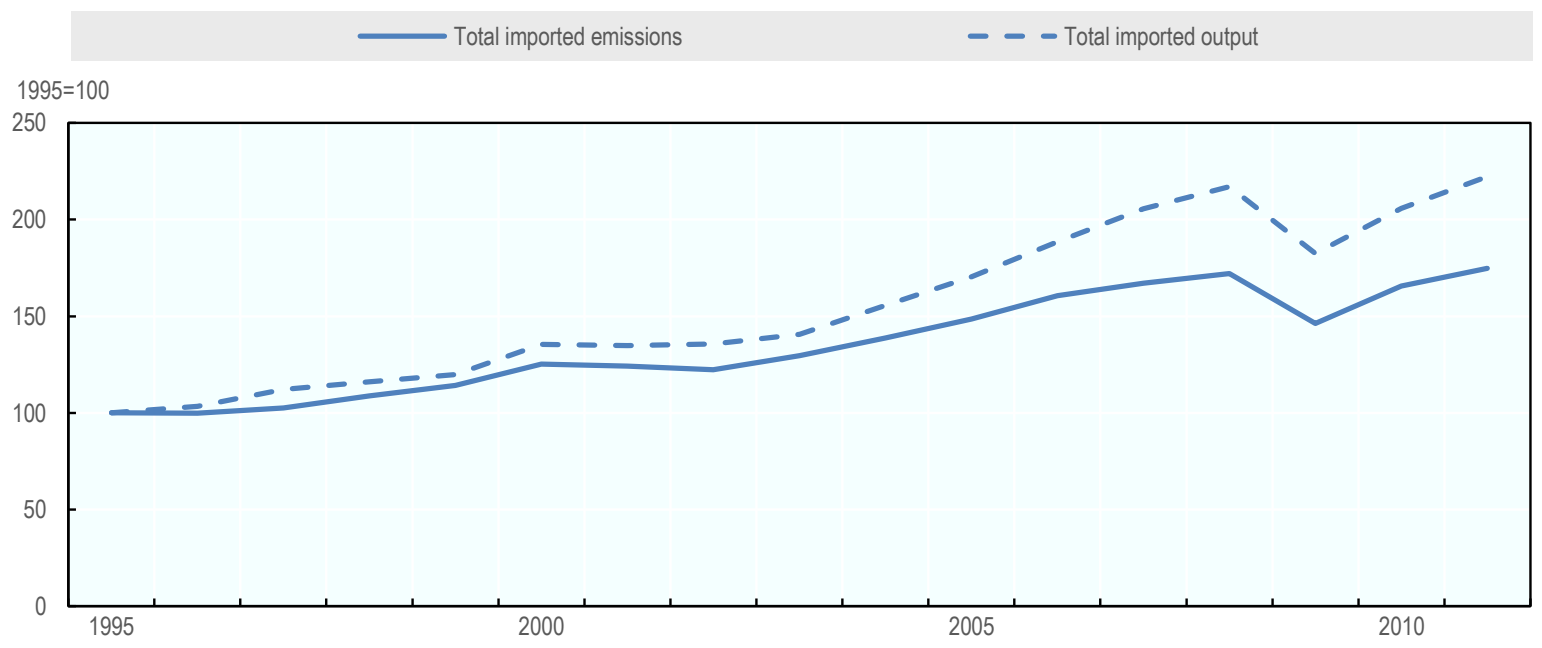

Note: All variables converted into 2010 constant USD to account for cross-country differences in inflation and movements in exchange rates.

Source: Authors' elaboration based on Wiebe and Yamano (2016) using the 2016 OECD Inter-Country Input-Output model and emissions from fuel combustion in International Energy Agency (2018).

Emissions embodied in trade tend to reflect the extent to which countries participate in global value chains (GVCs), with all countries shipping emissions through traded goods (Figure 3). Countries' income, endowments, and technology also play a role as exported carbon emissions are sometimes disproportional to its participation in global trade, for example, the People's Republic of China (hereafter "China") and the Russian Federation account for $23 \%$ and $10 \%$, respectively, of all carbon emissions embodied in exports while they make up for $13 \%$ and $3 \%$ of global trade value. 
Figure 3. Carbon emissions embodied in bilateral trade flows in 2011

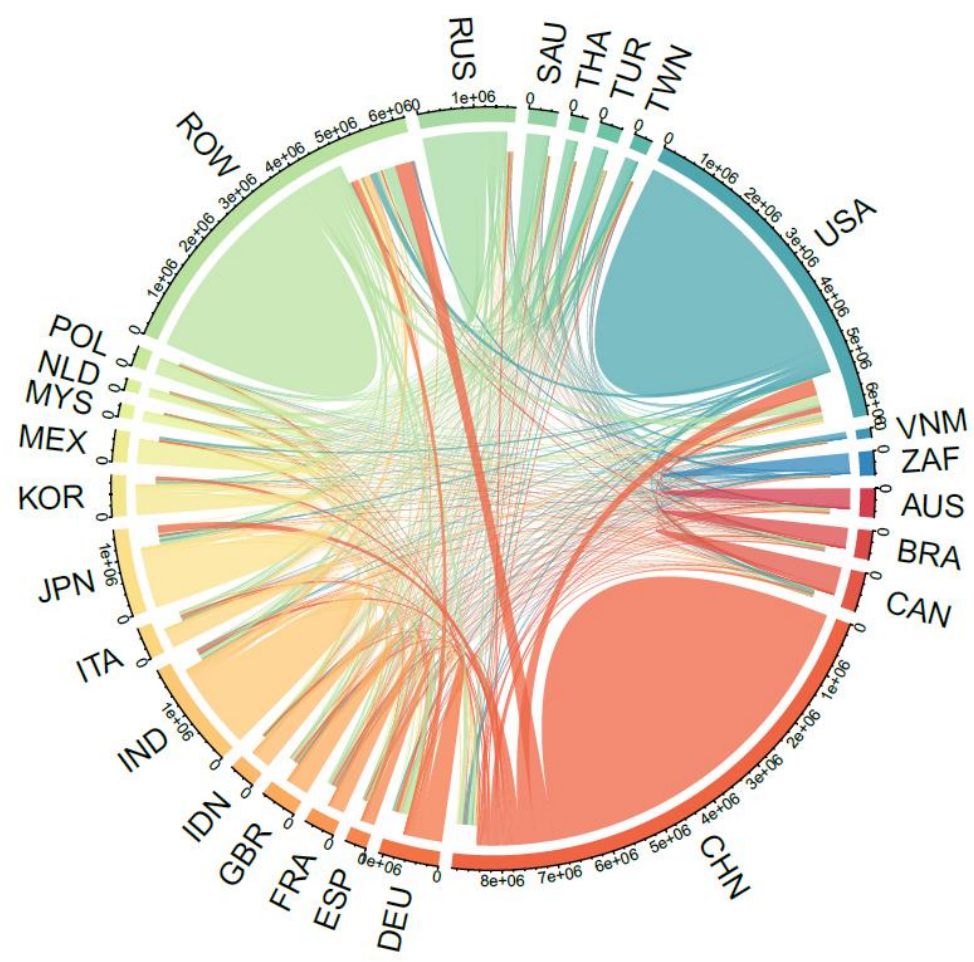

Note: The origin and destination of the flows indicate where the goods embodying carbon emissions are produced and then consumed.

Source: Authors' elaboration based on Wiebe and Yamano (2016) using the 2016 OECD Inter-Country InputOutput model and emissions from fuel combustion in International Energy Agency (2018).

\section{The reality of pollution havens}

In OECD countries, imported carbon emissions from both OECD and countries outside the OECD area have been growing, with the latter increasing proportionally more than the former (Figure 4). The carbon intensity of the basket of imports from OECD countries is lower than the carbon intensity of OECD domestic production and has slightly decreased over time (Figure 5). Imports from countries outside the OECD area are both more carbon intensive than OECD domestic production and have declined more substantially. 
Figure 4. Imported emissions in OECD countries (1995-2011)

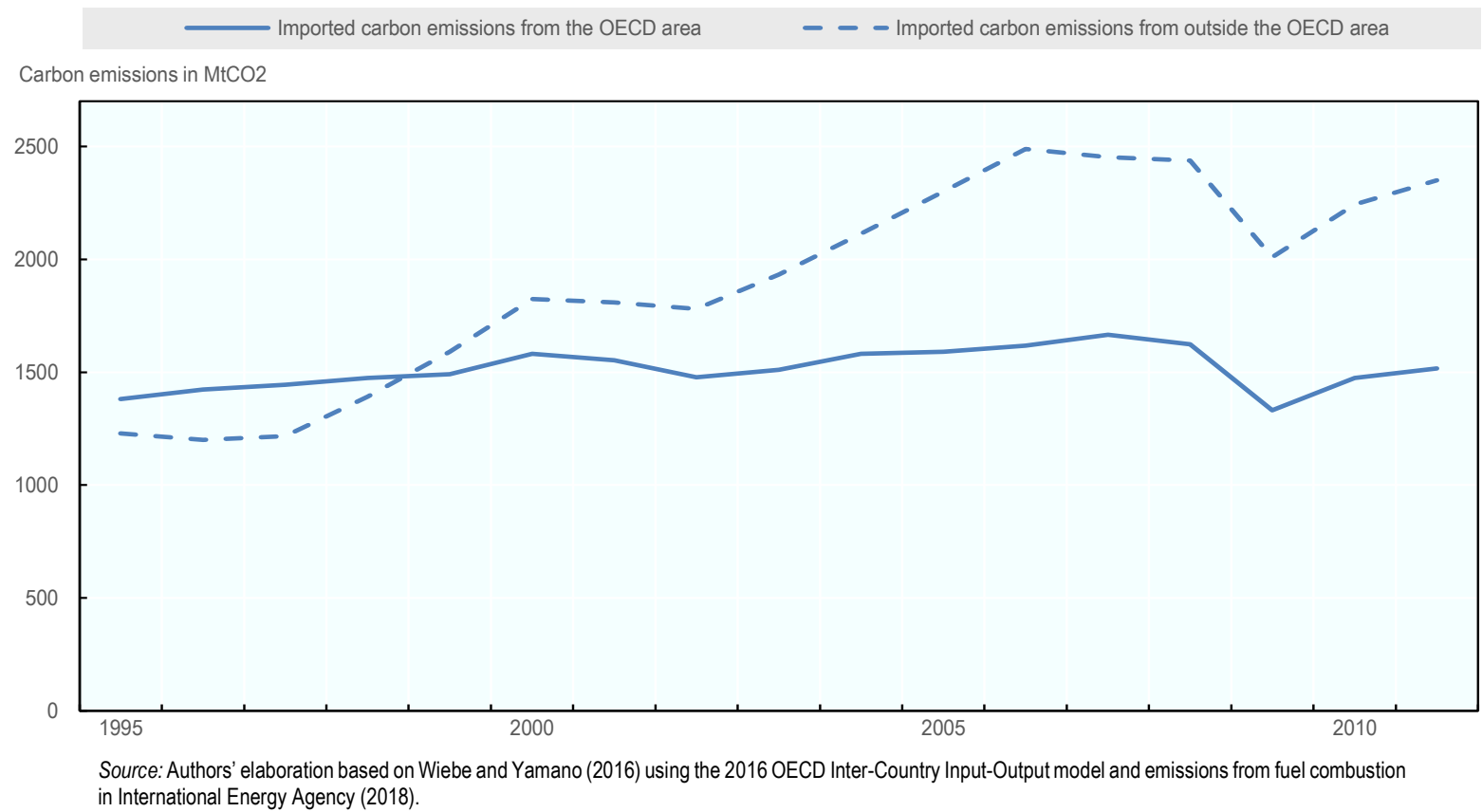

Figure 5. Carbon intensity of imports in OECD countries

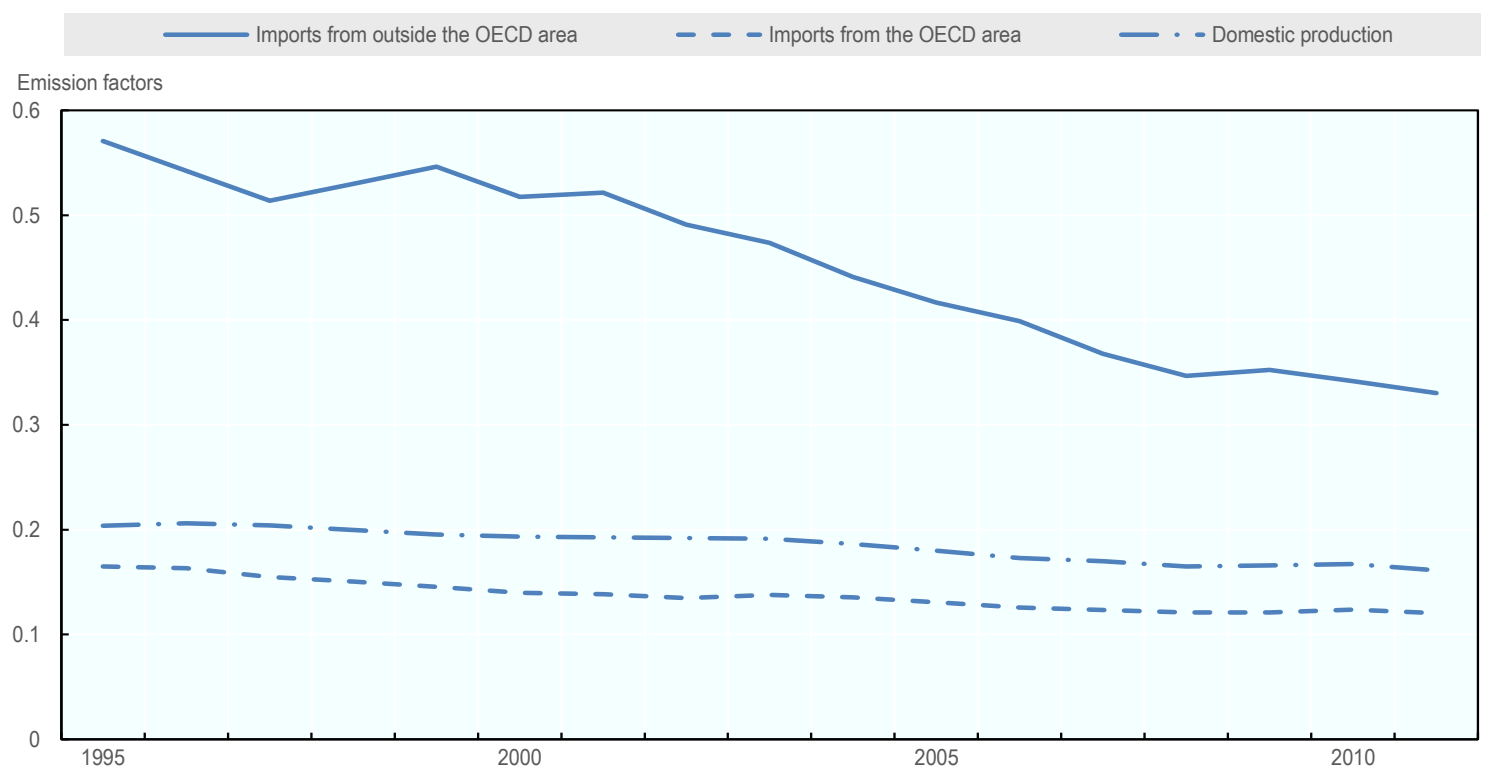

Note: Emissions factors of imports are calculated as the amount of imported emissions divided by the value of imported goods in final domestic consumption Emissions factors of domestic production are calculated as the amount of domestically generated emissions divided by the value of domestic goods in final domestic consumption. All variables converted into 2010 constant USD to account for cross-country differences in inflation and movements in exchange rates Source: Authors' elaboration based on Wiebe and Yamano (2016) using the 2016 OECD Inter-Country Input-Output model and emissions from fuel combustion in International Energy Agency (2018). 


\section{The role of technology as a driver of imported emissions}

This (relative) clean-up in countries outside the OECD area is due to technological improvements. Imported emissions from countries outside the OECD areaincreased by 91\% between 1995 and 2011 (Figure 6). Decomposing this increase into scale, composition and technique effects shows that the technique effect accounts for -207 percentage points (pp) of the total increase, while the scale and the composition effects account for $230 \mathrm{pp}$ and $68 \mathrm{pp}$ respectively (Figure 7). In other words, the basket of imports from countries outside the OECD area has grown much larger in volume (scale effect) and more carbon intensive in its composition (composition effect). However, at present, technology improvements (technique effect) have partly offset these two effects on carbon emissions.

Similarly, the technique effect plays a significant role in slowing growth in imported emissions from OECD countries, which have increased by only $10 \%$. The technique effect $(-58 \mathrm{pp})$ more than offset the scale effect $(51 \mathrm{pp})$, the main driver of growth in imported emissions. The composition of imports has become slightly more carbon intensive as the composition effect is positive (17 pp).

Figure 6. Imported emissions in OECD countries by scale, composition and technique effects
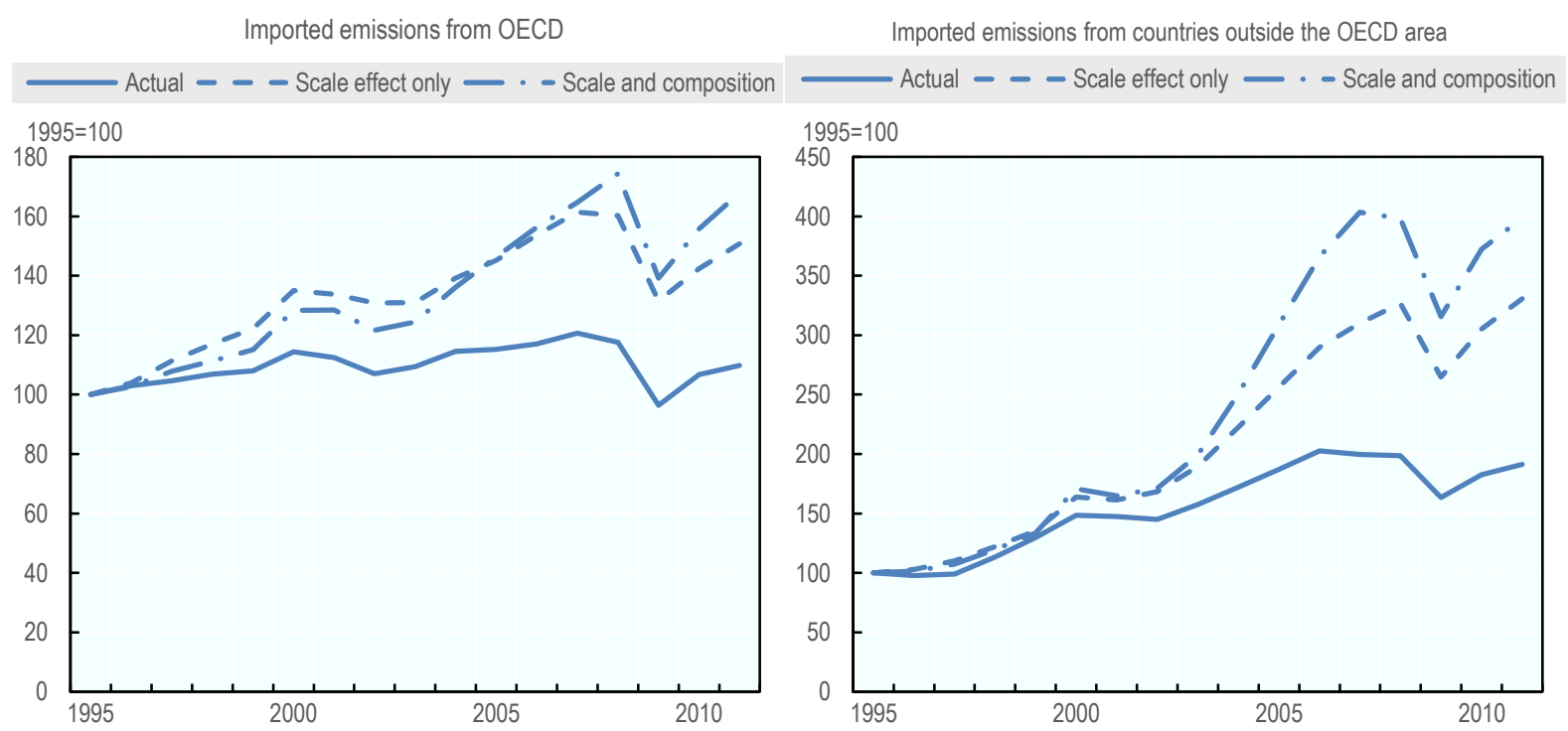

Note: The hypothetical imported emissions by scale effect only are the hypothetical amount of carbon emissions associated with the final demand that would have been generated in other countries if both the composition of industries making the final demand and emissions factors would have remained constant over time (scaled so that the 1995 value equals 100). The hypothetical imported emissions by scale and composition effects are the hypothetical amount of carbon emissions associated with the final demand that would have been generated in other countries if emissions factors would have remained constant over time (scaled so that the 1995 value equals 100). All variables converted into 2010 constant USD to account for cross-country differences in inflation and movements in exchange rates.

Source: Authors' elaboration based on Wiebe and Yamano (2016) using the 2016 OECD Inter-Country InputOutput model and emissions from fuel combustion in International Energy Agency (2018). 
Figure 7. Decomposing the increase of imported emissions into the scale, composition and technique effects
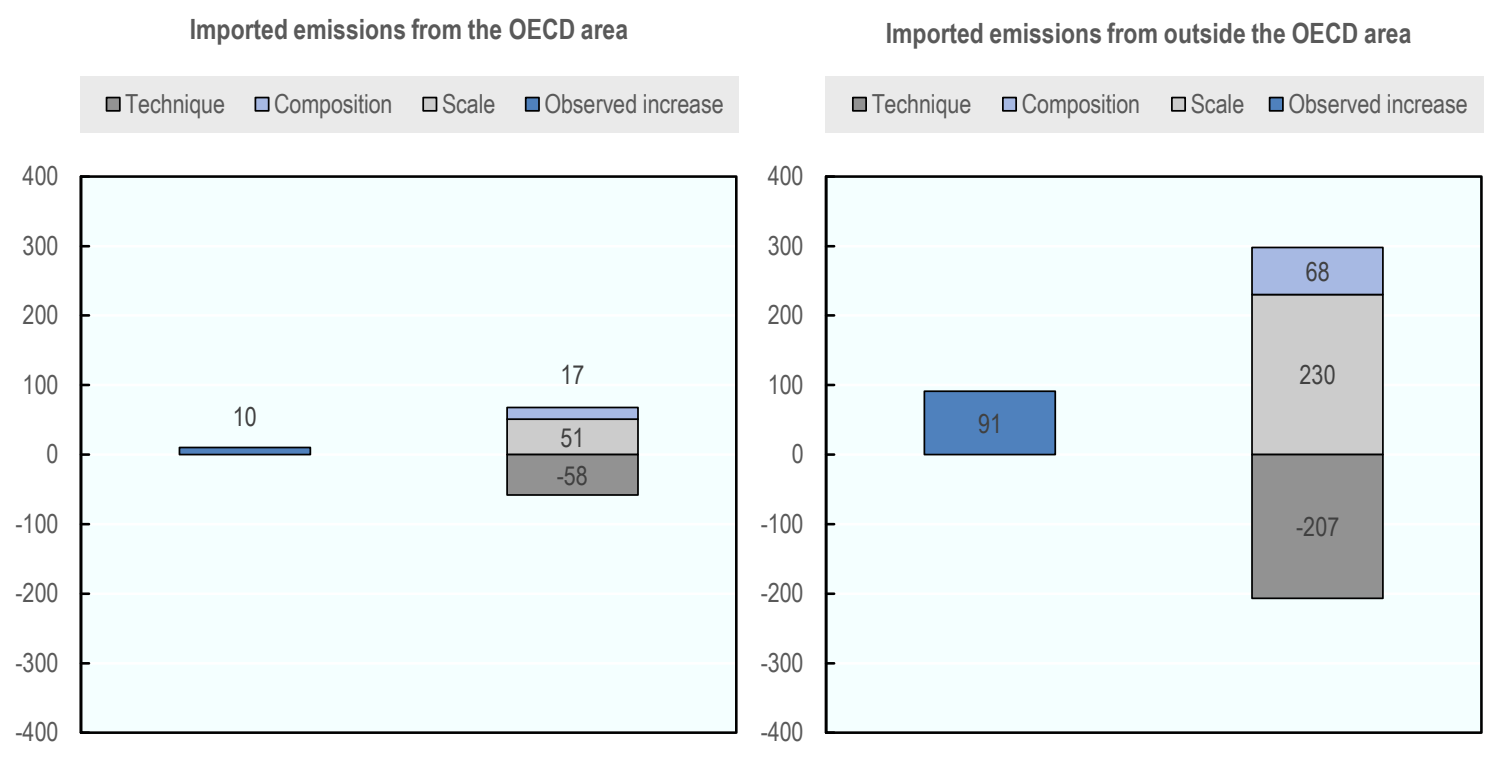

While technological improvements have decreased the carbon intensity of imports from countries outside the OECD area, the same goods would still be produced with lower emissions in OECD countries (Figure 8). In addition, this gap is not closing, meaning that the decarbonisation of industrial processes producing these goods is happening at a faster pace in OECD countries than elsewhere. The opposite is true for imported emissions from OECD countries: a larger amount of emissions would have been generated had the same goods been manufactured in the countries where they are imported, with this difference growing over time. This suggests that intra-OECD trade allows goods to be produced where carbon intensity is lower.

\section{Conclusions and future research}

These trends are in line with studies that carried out a similar exercise (Fernandez-Amador, François and Tomberger, 2016) and point to the existence of potential pollution haven effects. OECD countries import more carbon-intensive goods from countries outside the OECD area. Although these goods are being produced with a declining carbon intensity thanks to substantial improvements in technology, industrial processes in OECD countries are generally cleaner.

These results open several avenues for future research. One is identifying the drivers of these observations, and especially whether cross-country differences in the stringency of environmental policies plays a role. Previous analyses have estimated that the latter has an effect only on a limited number of industries, namely those that are energy-intensive industries (Kozluk and Timiliotis, 2016; Garsous and Kozluk, 2017). These studies have focussed, however, on trade or FDI flows; more research is needed to understand how these translate into carbon emissions flows. Secondly, it is necessary to determine with greater accuracy the reasons behind the decline in the carbon intensity of imports from countries outside the OECD area. Does clean technology diffusion play a role and how can international trade in environmental goods facilitate carbon intensity reductions? These questions could be addressed through more empirical analyses. 
Figure 8. Imported emissions in OECD countries using the Equal Carbon Intensity (ECI) assumption
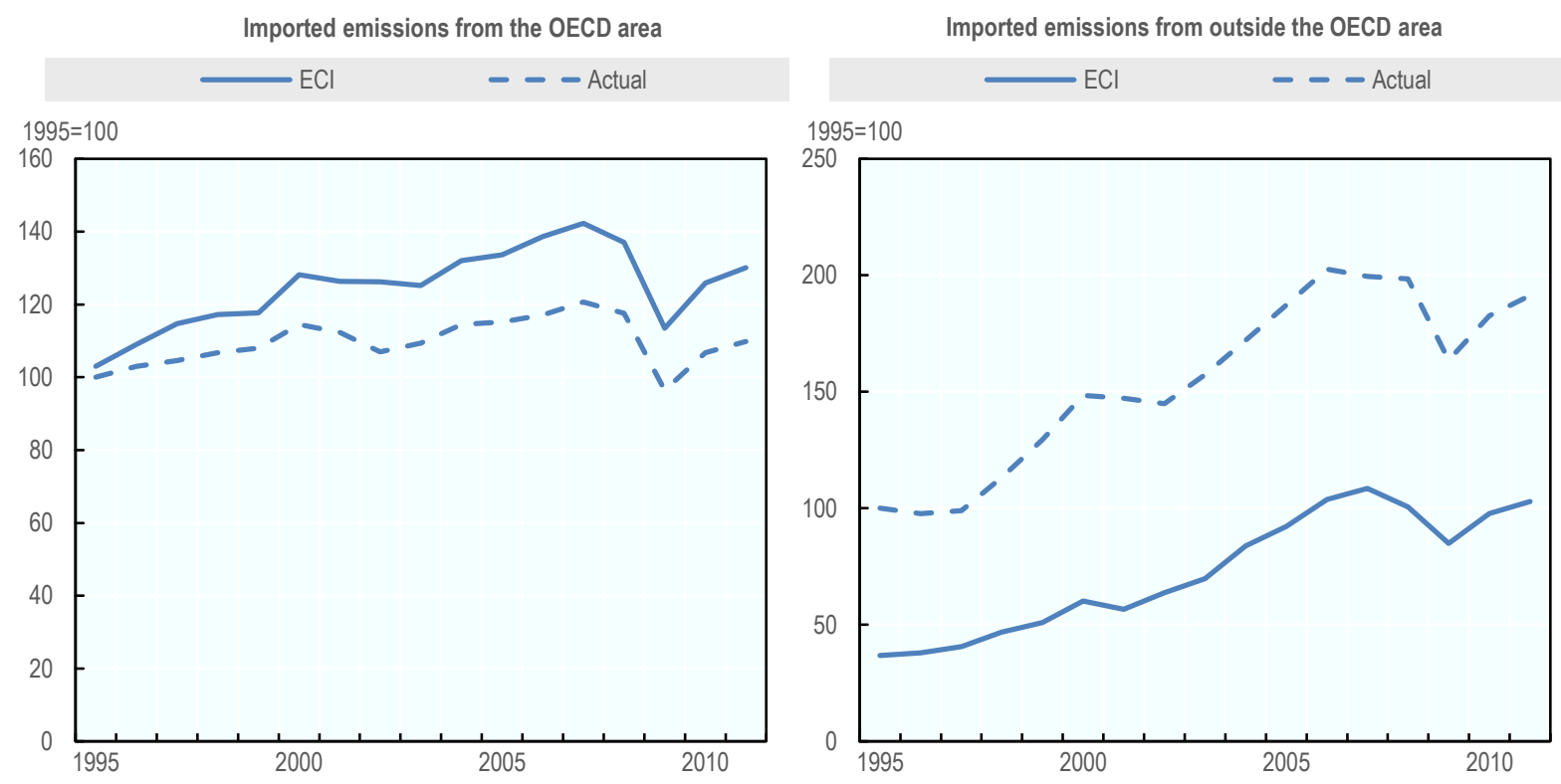

Note: Equal Carbon Intensity (ECl) imported emissions is the hypothetical amount of carbon emissions associated with the final demand that would have been generated had imported goods been produced with a carbon intensity (i.e. emissions factors) equal to the importing country (divided by the 1995 value of actual emissions). All variables converted into 2010 constant USD to account for cross-country differences in inflation and movements in exchange rates.

Source: Authors' elaboration based on Wiebe and Yamano (2016) using the 2016 OECD Inter-Country InputOutput model and emissions from fuel combustion in International Energy Agency (2018).

\section{Raw materials embodied in trade}

\section{Definition of the indicator}

This indicator ${ }^{9}$ estimates the total raw materials embodied in final consumption for each country between 1990 and 2010. Estimates of this indicator are called material footprint (MF) or Raw Material Consumption (RMC). The different categories of raw materials considered are biomass, fossil fuels, metal ores, and non-metallic minerals.

\section{State of the progress of the indicator}

The development of this indicator is intermediate. It allows for a descriptive analysis as described below. At present, the drivers of raw materials embodied in trade cannot be identified. This would require the indicator to be introduced into an econometric model. Nevertheless, carrying out such a quantitative exercise is desirable and would allow for greater insights into how country differences with related environmental policy stringency affect the patterns of trade in embodied raw materials.

9 Source for this indicator are UNEP International Resource Panel, 2016). See Annex A for full details. Note that this measure does not include secondary materials (e.g. scrap) and focusses exclusively on primary (i.e. raw) materials. 


\section{Main messages}

- Raw materials embodied in goods shipped across borders increased by $146 \%$ between 1990 and 2010, accounting for $36 \%$ of total material extraction.

- Most countries are either importers or exporters of raw materials embodied in goods.

- Countries such as France, Germany, Japan, United Kingdom, and the United States have relied on a high level of raw material imports over the last 40 years.

- By contrast, countries such as Australia, Brazil, Chile, Indonesia, Kazakhstan, and the Russian Federation have specialised in extraction activities and are net exporters of raw materials.

\section{Policy context}

Global material extraction (biomass, fossil fuels, metal ores, and non-metallic minerals) has more than tripled over the past 40 years, growing from 22 billion tonnes in 1970 to 70 billion tonnes in 2010 (UNEP International Resource Panel, 2016). This trend accelerated as of 2000 and current trajectories of materials consumption are estimated to be above a sustainable level (Bringezu, 2015 $5_{[1]}$ ).

The expansion of global trade has played a major role in patterns of raw material extraction. Because no country is self-sufficient in every raw material, raw materials requirements in downstream stages of production can only be met through trade from the few countries where the required metals and minerals are found. Therefore, restrictions on trade in such materials are particularly disruptive to global supply chains (GVCs) (Korinek, 2018). Moreover, increased GVCs means that raw materials are often extracted in one country and consumed in others, including the manufacturing of goods. This leads to a further disconnect between the local costs borne by the extracting country (in particular, externalities in terms of waste, emissions and pollution) and the benefits enjoyed by foreign consumers. At the same time, the transition towards a more resource efficient and circular economy has broad linkages with international trade through the emergence of trade in secondary materials and waste (Yamaguchi, 2018).

An indicator estimating the consumption-based raw materials extraction - that is, raw material extraction associated with final demand, or the so-called material footprint allows to measure the embodied raw materials in imports and exports. Such a metric can contribute towards tracking progress on the decoupling of economic growth and material consumption. It would also enable the concentration in extraction locations to be measured and to shed light on the extent to which GVCs depend on those exporters.

\section{Main trends}

The acceleration in demand for raw materials since 2000 is largely due to the industrial and urban transformation of China, which has required unprecedented amounts of iron, steel, cement and other construction materials (UNEP International Resource Panel, 2016).

Trade in raw materials has followed this pace. Raw materials embodied in goods shipped across borders increased by $146 \%$ between 1990 and 2010, accounting for $36 \%$ of total material extraction (Figure 9). Because no country is self-sufficient in every raw material, the requirements in the downstream stages of production can only be met through trade with countries where the needed raw materials are found. In particular, rapid urbanisation 
in Asia and some parts of Europe have increased demand for cement and steel, translating into high growth of trade in non-metallic minerals (198\%) and metal ores (162\%).

Figure 9. Amount of raw materials embodied in global trade

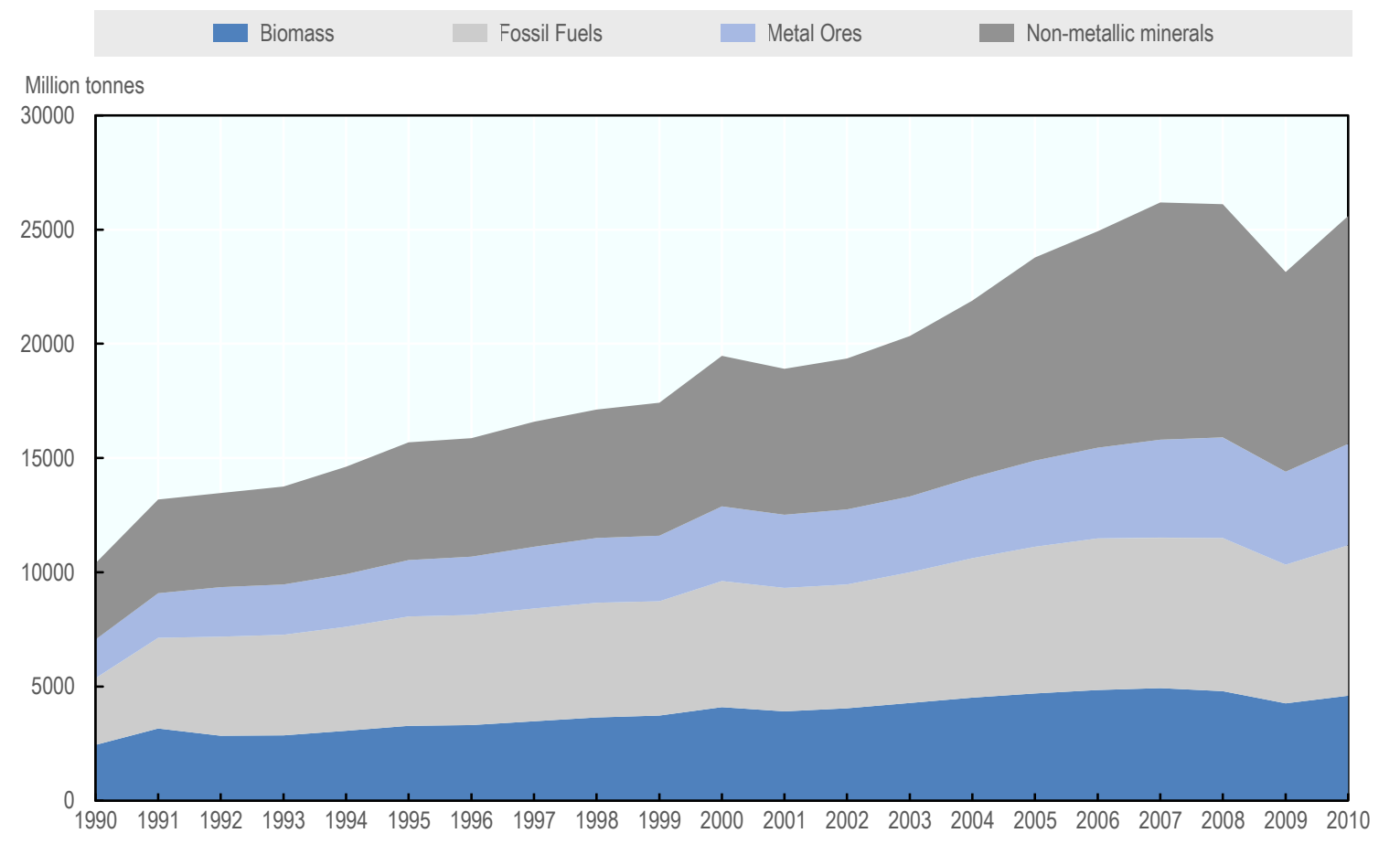

Source: UNEP International Resource Panel (2016).

Most countries have become either importers (Figure 10) or exporters (Figure 11) of raw materials. Countries such as the United States, Japan, Germany, the United Kingdom and France have relied on a high level of imports of raw materials over the last four decades (UNEP International Resource Panel, 2016). By contrast, countries such as Australia, Brazil, Chile, Indonesia, the Russian Federation, and Kazakhstan have long specialized into extraction activities and are clear net exporters of raw materials. China and India are both significant importers and exporters because they specialised in certain categories of raw materials. China has been mostly importing metal ores (especially iron ores from Australia and Brazil for steelmaking) and exporting non-metallic minerals (through cement exports), while the opposite is true for India. In 2010, OECD countries were all net importers of raw materials, with the exception of Australia, Chile, Estonia, Norway, New Zealand, and Poland. 
Figure 10. Top 20 importers of raw materials (by share of global trade in raw materials)

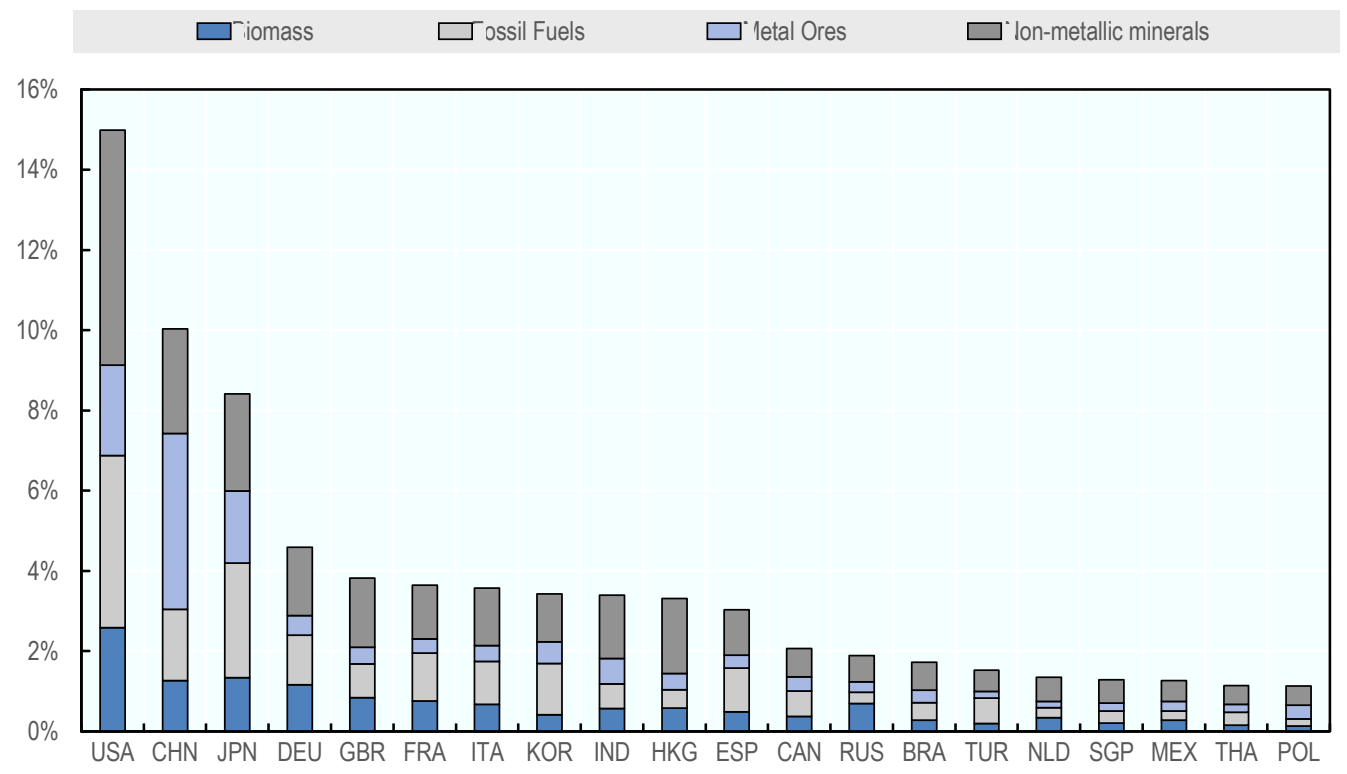

Source: UNEP International Resource Panel (2016).

Figure 11. Top 20 exporters of raw materials (by share of global trade in raw materials)

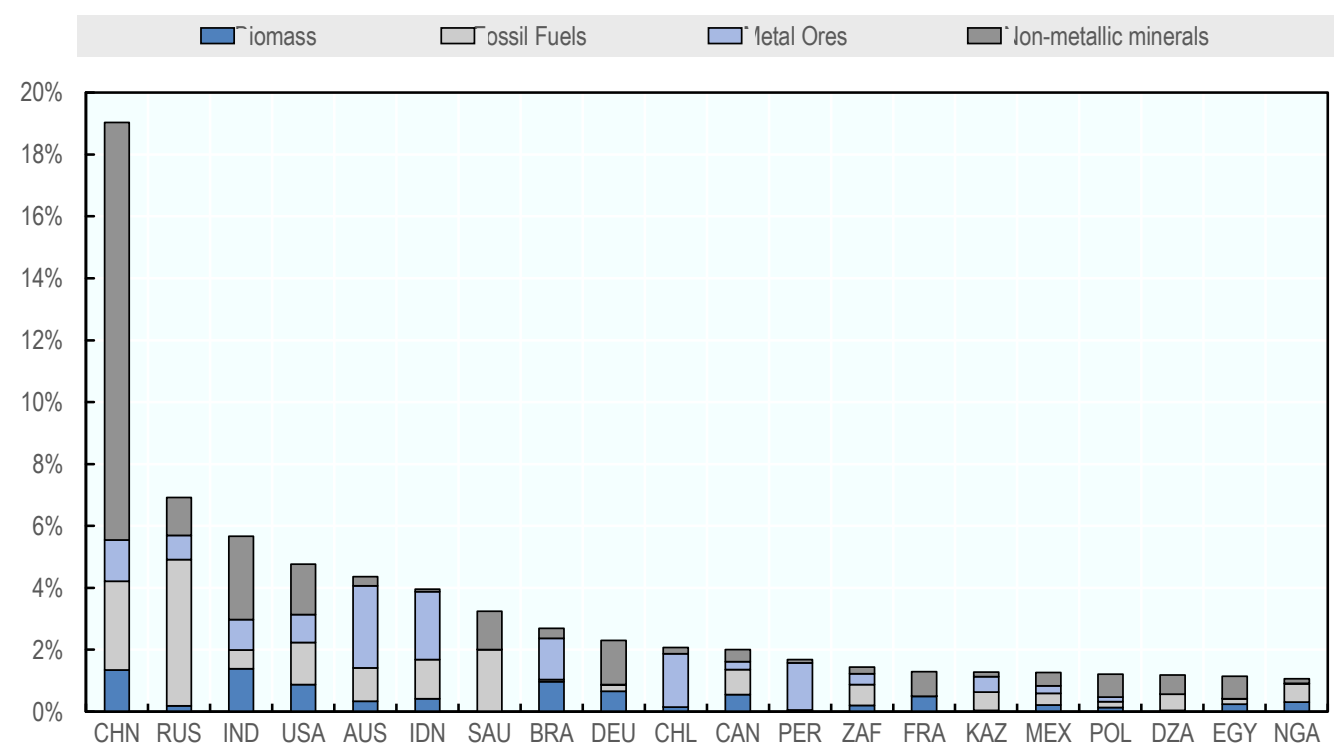

Source: UNEP International Resource Panel (2016). 


\section{Trade in environmentally-related goods}

\section{Definition of the indicators ${ }^{10}$}

\section{The volume of trade in environmentally related goods}

The amount of exports and imports of environmentally-related goods as defined in the Combined List of Environmental Goods (CLEG) in current USD for all countries between 2003 and 2016.

\section{Tariffs on environmentally related goods}

The import-weighted applied tariffs on environmentally-related goods as defined in the Combined List of Environmental Goods (CLEG) in percentage points for all countries between 2003 and 2016.

\section{State of the progress}

The development of these indicators is intermediate, allowing for some descriptive analyses (provided below). However, at this stage, the drivers of trade in environmentally-related goods cannot be identified. Introducing these indicators in an econometric model would allow for more insight on how a tightening in countries' environmental policy stringency creates markets for environmentally-related goods. In addition, as there is no consensus on which traded goods should be considered as "environmental", a refinement of the classification process based on new criteria, such as environment-related technologies, is needed to improve the quality of these indicators.

\section{Main messages}

Between 2003 and 2016, international trade in environmentally-related goods (EGs) ${ }^{11}$ more than doubled, from USD 531.10 billion to USD 1261.24 billion, and increased its share in global trade from $7.2 \%$ to $8.1 \%$.

Average tariffs applied on imports of EGs declined in OECD countries, from 1.6\% in 2003 to $0.8 \%$ in 2016. Tariffs in countries outside the OECD area were significantly higher but also declined, from $7.4 \%$ in 2003 down to $4.1 \%$ in 2016.

China has become a dominant player of international trade in environmentally-related goods; it was the top exporting country and the second-top importing country in 2016.

\section{Policy context}

Recent international agreements - the Paris Climate Agreement and the 2030 Agenda for Sustainable Development - have shaped a new multilateral context with ambitious

10 Sources for these indicators are BACI International Trade database and UNCTAD Trade Analysis Information System (TRAINS). See methodological notes for full details.

11 The environmentally related goods refer here to the Combined List of Environmental Goods (CLEG) as used in Sauvage (2014), which provides the Harmonized System 6-digit level codes of 248 products. There is no consensus on which traded goods should be deemed "environmental" and relying on this list is a practical approach to overcome the challenges to defining an internationally argued list of environmentally-related goods. See methodological annex of the indicator on trade in environmentally related goods for a full discussion. 
environmental targets. To achieve the associated objectives, countries are expected to raise the level of stringency of their environmental policies. This in turn can generate higher demand for environmentally-related goods and services as firms seek to comply with new environmental regulations; this would have significant implications on international markets where these goods and services are traded. Removing trade barriers for environmentally related goods (EGs) can contribute to achieving this agenda by facilitating the diffusion of equipment and technologies necessary to abate or avoid environmental damage. Two indicators are proposed to address this issue.

First, an indicator on the volume of trade in environmentally-related goods can help analyse how the interrelationship between environment and trade and the impact of their policies contributes to achieving environmental goals. In particular, stringent environmental policies can incite firms and households to acquire new equipment and techniques to alleviate the compliance costs of new environmental regulations. This could generate higher demand for environmentally-related goods and services that may have significant implications on international markets. As firms tend to concentrate their activities in larger markets to benefit economies of scale and avoid transportation costs, ${ }^{12}$ recent empirical evidence suggests that more-stringent environmental policies are associated with more exports in environmentally-related goods (Sauvage, 2016) and services (Sauvage and Timiliotis, 2017). This indicator may also help to better understand how trade can improve clean technology diffusion across countries, particularly in the context of regional trade agreements that have environmental provisions.

Second, an indicator that measures the tariffs rates on environmentally-related goods will also help to monitor the evolution of trade liberalisation of EGs. While multilateral trade negotiations to reduce tariffs are currently stalled at the WTO, trade liberalisation in EGs could move forward through regional binding or voluntary initiatives such as the APEC agreement to cut tariffs on a list of 54 environmentally-friendly goods in 2016.

\section{Main trends}

Between 2003 and 2016, global trade in environmentally-related goods (EGs) more than doubled, from USD 531.10 billion to USD 1261.24 billion, representing an average annual growth of $7.5 \%$ (Figure 12). In relative terms, the share of trade in environmentally related goods in global trade grew from $7.2 \%$ to $8.1 \%$. Exports of all environmentally related goods have experienced positive growth. Renewable energy plants (REP) experienced the highest growth rate, with an average of $8.9 \%$, driven largely by solar photovoltaic systems. This is consistent with recent trends in energy generation and use, as countries around the world have been shifting towards greater renewable energy use, particularly in electricity generation (IEA, 2018). In 2016, renewable energy plants (REP) accounted for the single largest proportion of exported EGs $(34.7 \%)$. The other three largest traded mediums are wastewater management and potable water treatment [WAT] (19.4\%); environmental monitoring, analysis, and assessment equipment [MON] (10.7\%); and management of solid and hazardous waste and recycling system $[\mathrm{SWM}](8.8 \%)$. These four mediums combined represent $73.6 \%$ of all EGs goods traded worldwide.

12 This effect is known as the "home-market" effect (Krugman, 1980). It predicts that if goods are differentiated and there is free entry to markets, an increase in the size of the home market of a good leads to an increase in net exports of this good. 
Figure 12. Renewable Energy Plants (REP)

is the single largest exported environmentally-related goods medium

Global environmentally related goods (EGs) exports by environmental medium, 2003-2016

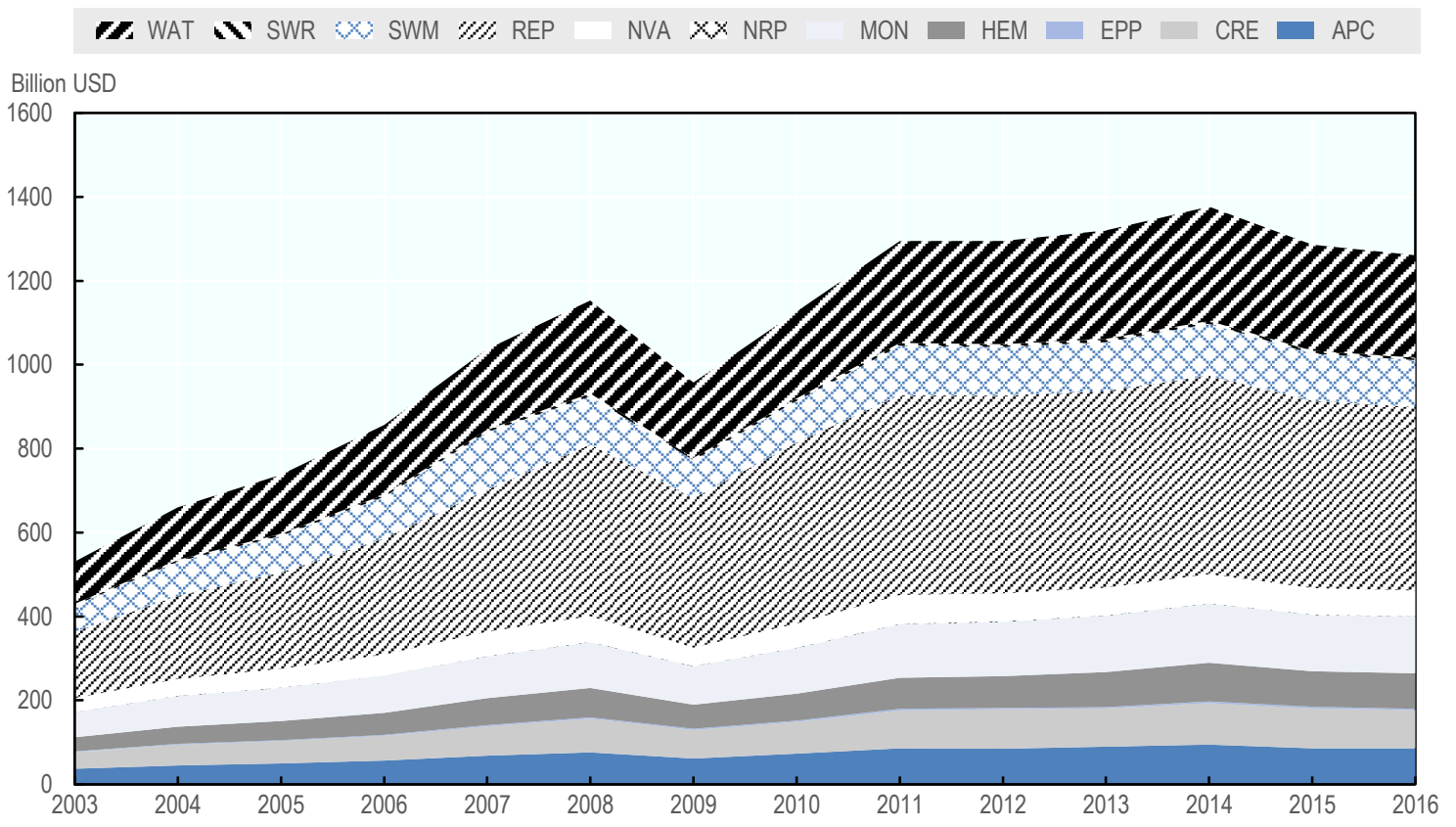

Note: WAT $=$ Waste water management and portable water treatment; SWR $=$ Clean up or remediation of soil and water; SWM = Management of solid and hazardous waste and recycling systems; REP = Renewable energy plant; NVA $=$ Noise and vibration abatement $N R P=$ Natural resources protection; $M O N=$ Environmental monitoring, analysis and assessment equipment; $\mathrm{HEM}=$ Heat and energy management; $\mathrm{EPP}=$ Environmentally preferable products based on end use or disposal characteristics; CRE = Cleaner or more resource efficient technologies and products; APC = Air pollution control.

Source: BACI International Trade database.

The OECD's relative share of the total exports in EGs has been continuously decreasing (Figure 13). OECD countries accounted for $80.6 \%$ and $66.9 \%$ of EGs exports in 2003 and 2016 respectively. Symmetrically, exports from countries outside the OECD area have been growing at a higher rate $-12.3 \%$ on average against $5.9 \%$ for OECD countries driven mostly by People's Republic of China (herafter "China") exports (Box 1). China's EGs exports now account for $19.4 \%$ of the share in global EGs exports, from just around $8.0 \%$ in 2003 . While less salient, the same trend appears for imports in EGs, the OECD countries have decreased their relative share of global imports in EGs - representing $62.69 \%$ of global imports in 2016 down from $70.0 \%$ in 2003. Imports in countries outside the OECD area have therefore been relatively increasing with Chinese imports contributing the most to this pattern as they account for $77.6 \%$ of imports in this area in 2016. 
Figure 13. The OECD's share in global trade in environmentally related goods has been decreasing, 2003-2016

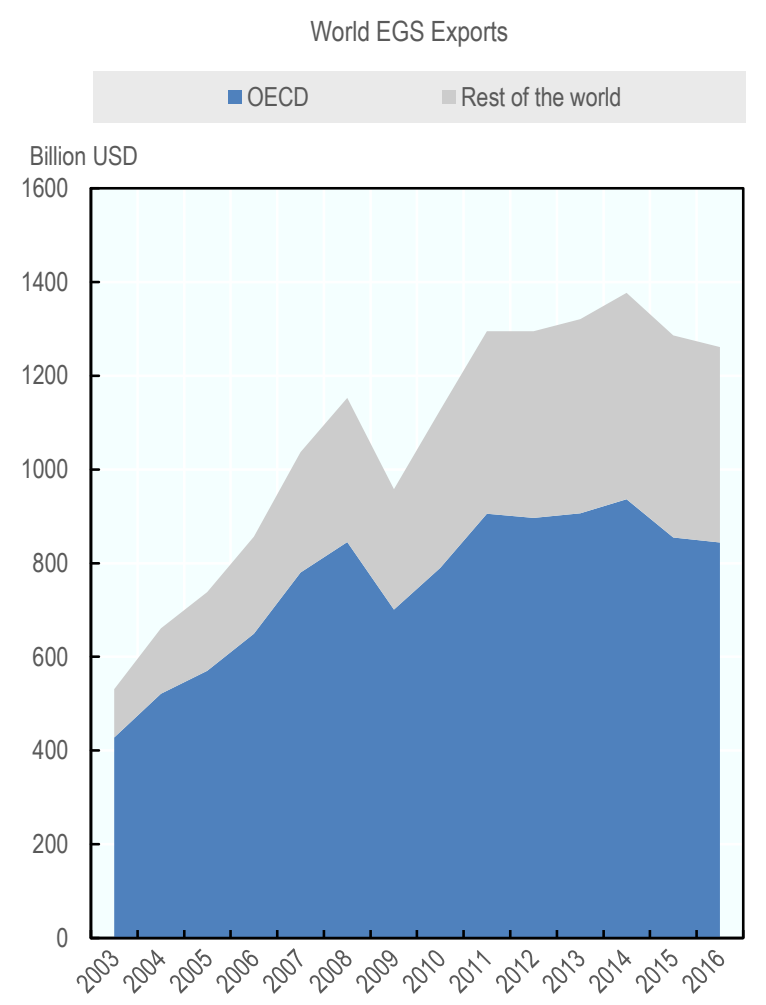

World EGS Imports and tariff rates

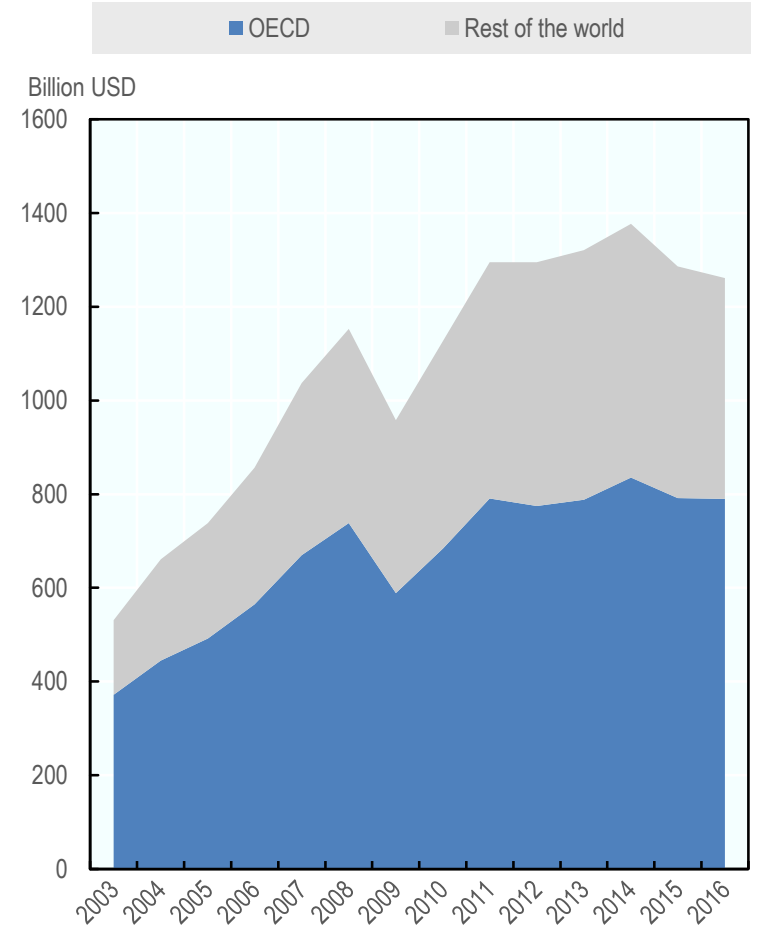

Source: BACI International Trade database.

Figure 14. There is a considerable difference in EGs' tariffs between the OECD countries and countries outside the OECD area amid signs of decreasing gap

Evolution of EGs import-weighted average tariff rates, 2003-2016

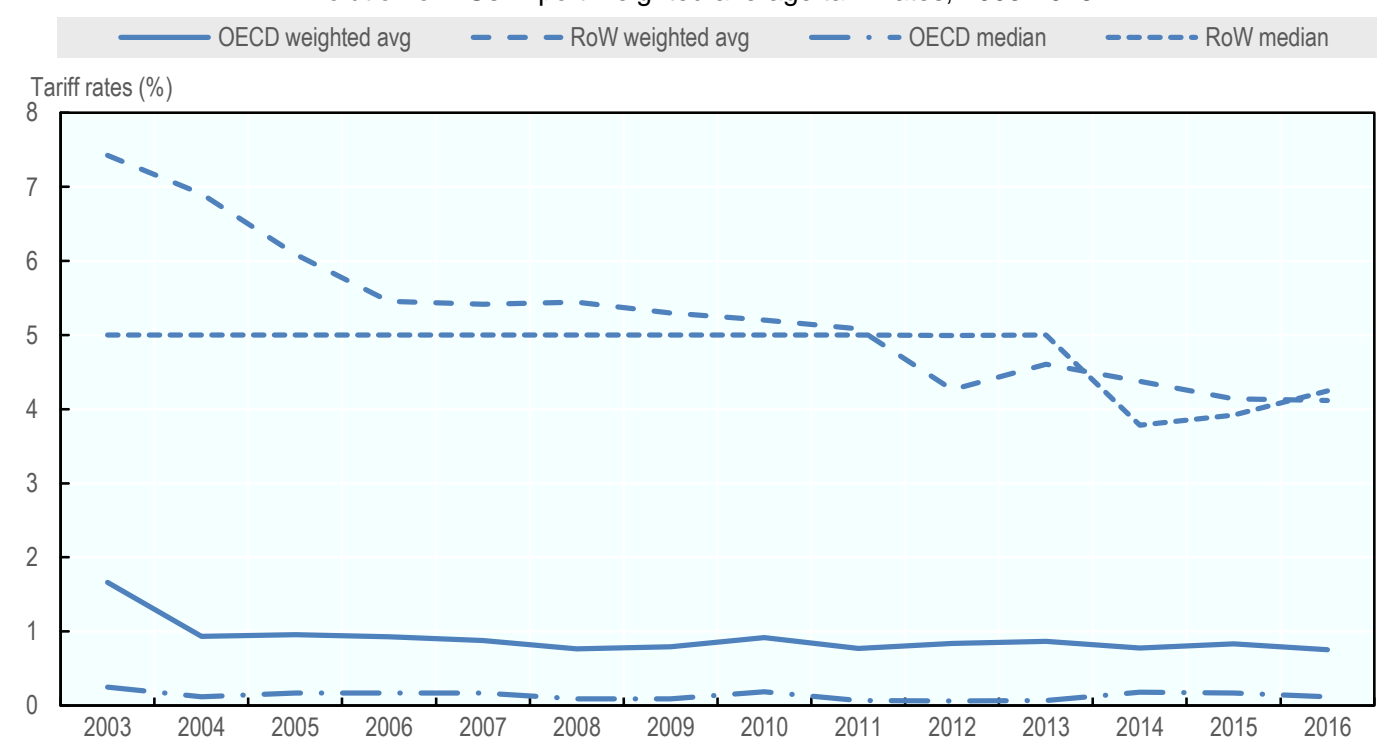

Note: RoW = Rest of the World

Source: BACI International Trade database and UNCTAD Trade Analysis Information System (TRAINS). 
On the whole, average tariffs applied on imports of EGs have been low and still declining in OECD countries, from $1.7 \%$ in 2003 to $0.8 \%$ in 2016 (Figure 14). Tariffs in countries outside the OECD area have been significantly higher but have also been declining, from 7.4\% in 2003 down to $4.1 \%$ in 2016. Median tariffs have to some extent followed the same trend, suggesting that the decline observed in average tariffs applied outside the OECD area is partly accounted for by tariff reductions applied on a large number of EGs rather than reductions on selected EGs as high-tariff outliers.

The dispersion of tariffs is also significantly different between OECD countries and countries outside the OECD area (Figure 15). Most of the tariffs on EGs in OECD countries do not differ from their low-level average whereas the distribution of tariffs in countries outside the OECD area is much more widespread, exhibiting both very low and very high tariffs on EGs. However, high-tariff outliers are present in both OECD countries and countries outside of the OECD area it. ${ }^{13}$

\section{Figure 15. High-tariff outliers are applied in both OECD countries and countries outside the OECD area}

Import tariffs for top 15 EGs importing countries, 2016

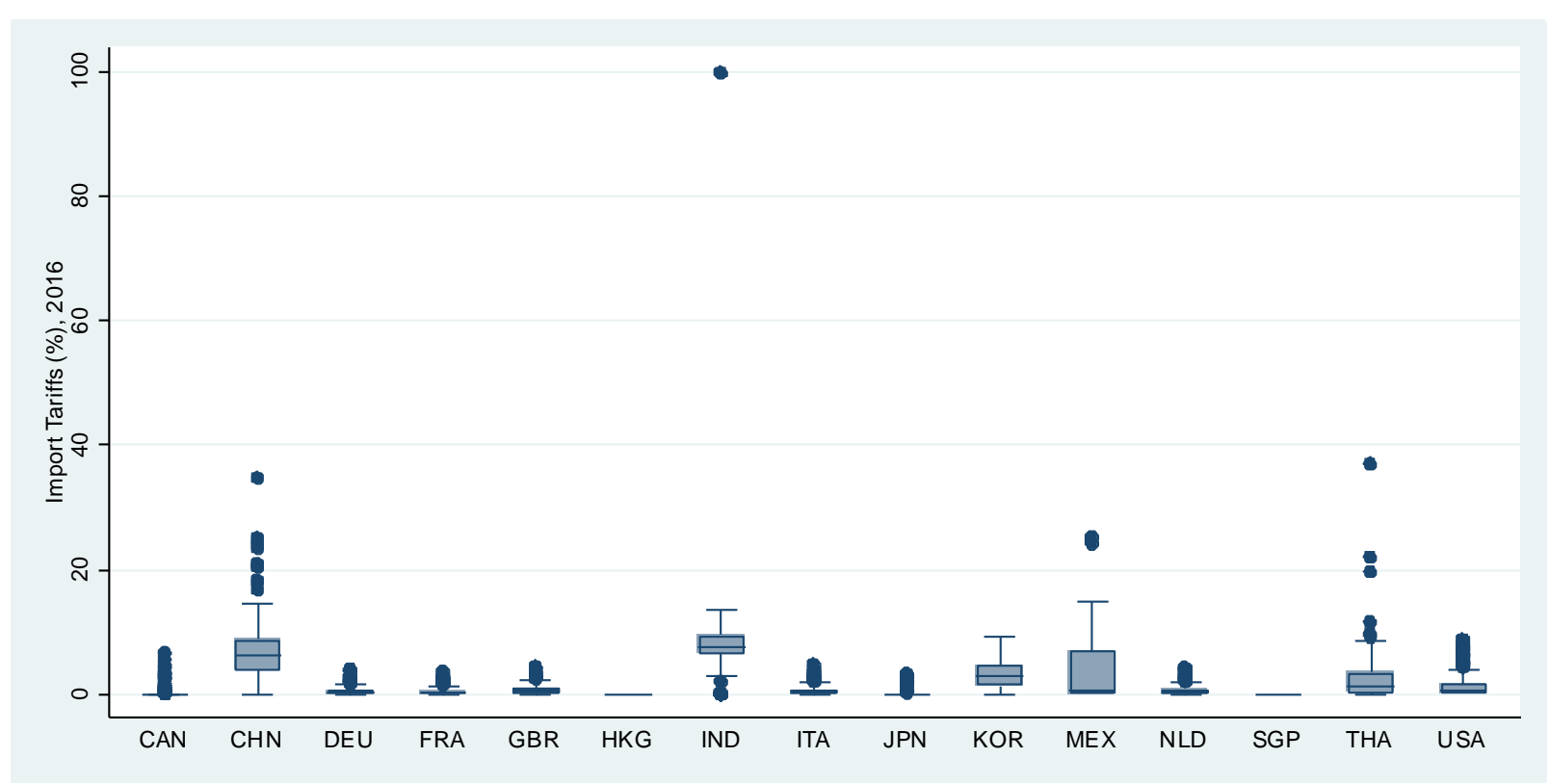

Source: BACI International Trade database and UNCTAD Trade Analysis Information System (TRAINS).

13 The most frequent of these outliers can be traced to a single product, passenger motor vehicles (HS code 8703.90 ), which is levied a tariff of $25 \%$ in China, $100 \%$ in India, $25 \%$ in Mexico and $39 \%$ in Thailand. 
Box Error! No text of specified style in document..1. China's rise in international markets for environmentally-related goods

In just over a decade, China has risen to become a dominant player of international trade in environmental goods (EGs). In 2003, China was last among the four major EGs exporting countries (Figure 16). It overtook Japan in 2006 and the United States in 2007. By 2010, China overtook Germany and became the top EGs exporting nation. It has held this position ever since, posting its highest exports in 2015 before contracting slightly in 2016.

China has been the main driver in the growth of EGs exports from countries outside the OECD area. In 2003, China's share in the total EGs exports from outside the OECD area was less than half, at just over $40 \%$. Thirteen years later in 2016, the bulk of these exports now originate from China, at nearly $60 \%$ share (Figure 17, right).

Figure 16. China's rapid rise in the EGs exports market

EGs exports by top-four major exporters, 2003-2016

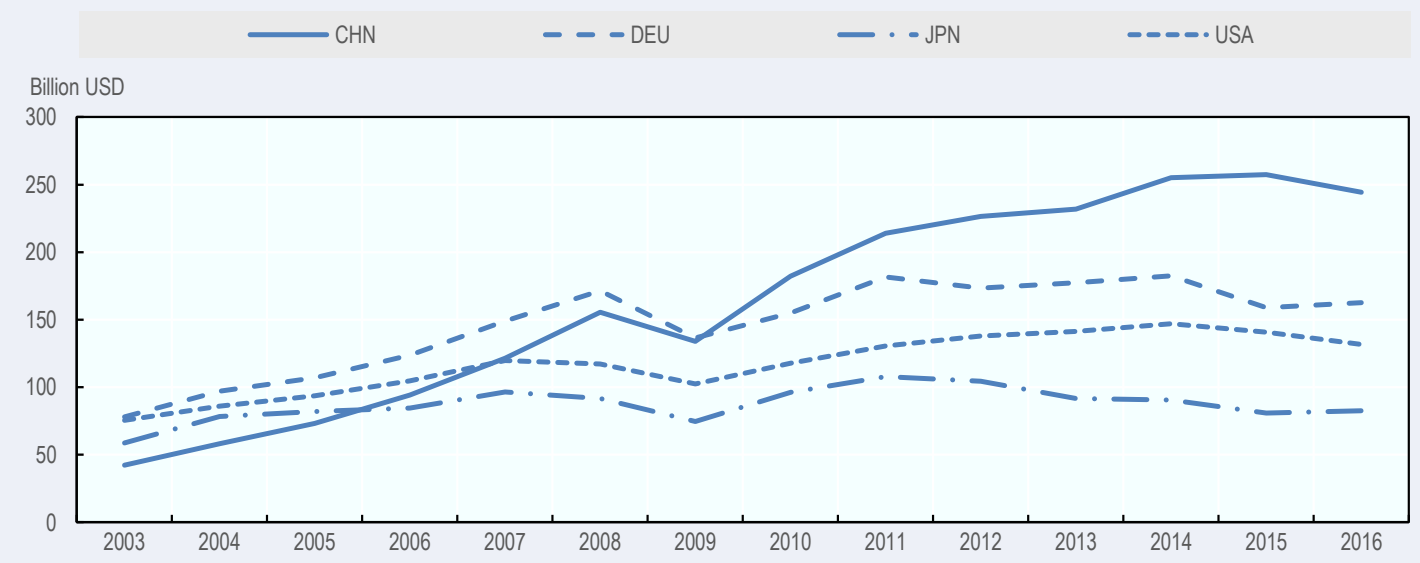

Source: BACI International Trade database.

Figure 17. China is the main driver of EGs exports from countries outside the OECD area

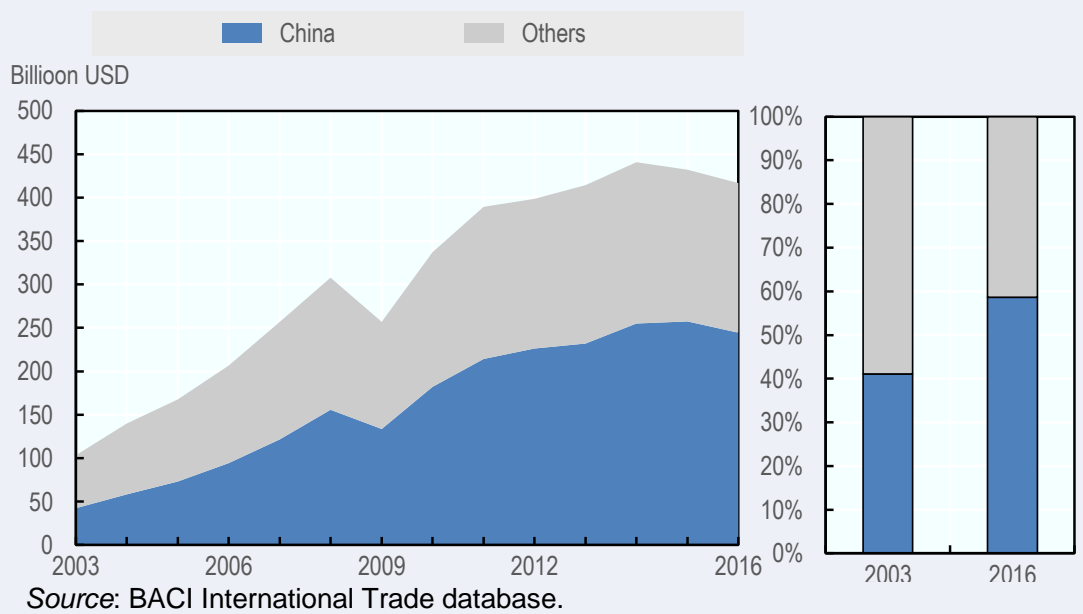

In terms of medium, China exported USD 102.18 billion worth of renewable energy plants (REP) in 2016. To put into context, this single medium in China's exports is larger than the total exports (i.e. for all mediums) from seven major EGs exporting countries, including Japan, Korea and Italy (Figure 18). China has also become a significant importer of EGs. In 2004-2008, China's imports have grown at an average of $21.1 \%$, overtaking Germany as the second largest EGs importer (Figure 19). Following the 2009 crisis, the country nearly tied with the United States, the top EGs importer, and then stabilised in second place. 
Similar to its exports, China's Renewable Energy Plants (REP) sector figures prominently among its EGs imports, worth USD 49.76 billion (Figure 20). In particular, China's REP imports are larger than the entire 2016 EGs imports in seven major EGS importers, including Mexico, the United Kingdom and France, among others.

Figure 18. China's renewable energy plant exports is larger than the total EGs exports of seven countries

Top-ten EGS exporters, 2016

$\square R E P$

口WAT

$\square \mathrm{MON}$

口SWM

$\square \mathrm{OTH}$

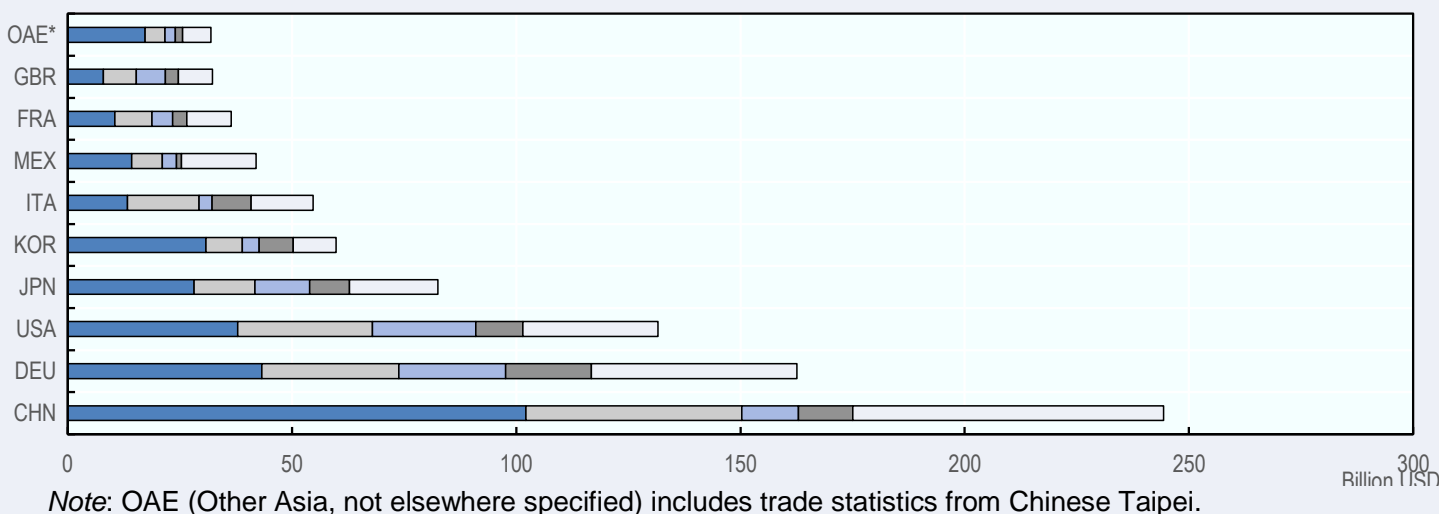

Note: OAE (Other Asia, not elsewhere specified) includes trade statistics from Chinese Taipei.

Source: BACI International Trade database.

Figure 19. EGs imports by top-five major importers, 2003-2016
$\longrightarrow \mathrm{CHN}$
$---D E U$
- - - FRA
- - -.JPN
- . USA

Billion USD

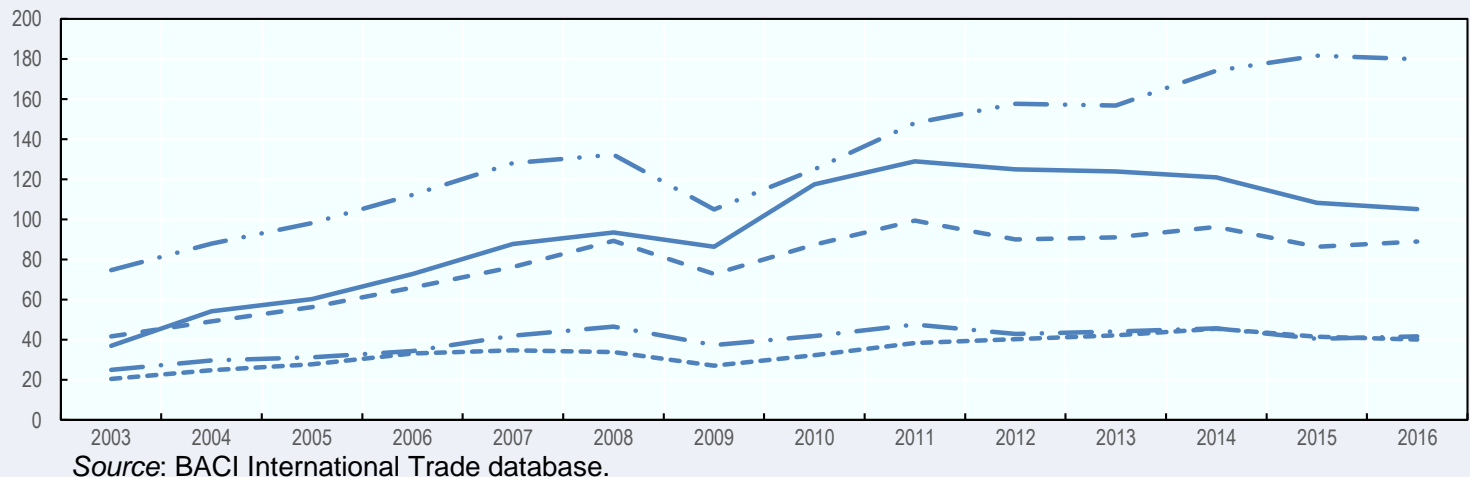

Figure 20. Top-ten EGs importers by medium, 2016 


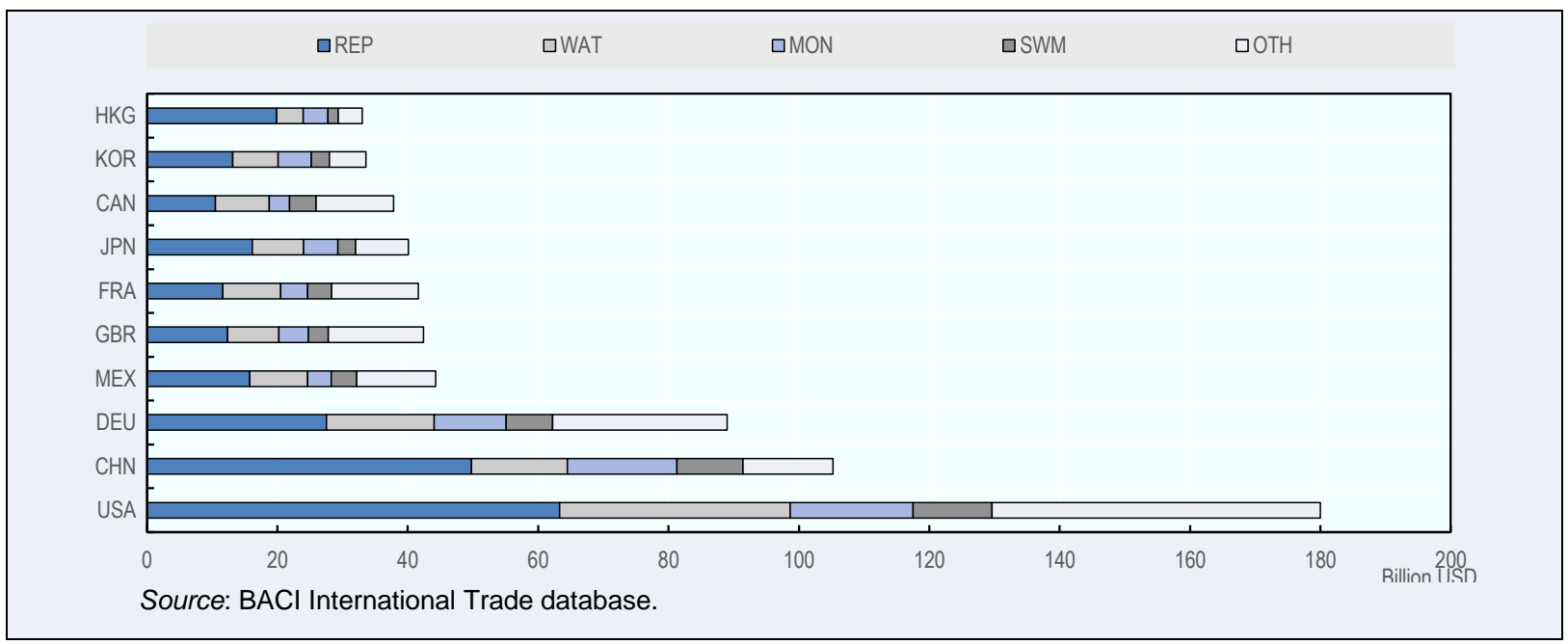

\section{Support to fossil fuels and renewable energy}

\section{Definition of the indicators ${ }^{14}$}

\section{Support measures for fossil fuels}

Support to fossil fuels reports the amount provided by governments to fossil fuel producers and consumers in current USD, through direct transfers and revenue forgone, for 76 countries between 2007 and 2015. ${ }^{15}$

\section{Enabling policy and regulatory environment for renewable energy}

This indicator reports scores between 0 and 100 - with 100 representing the best performance - that capture the extent to which a country's policy and regulatory environment encouraged renewable energy production and consumption; 111 countries were covered in $2015 .^{16}$

\section{State of the progress}

The development of these indicators is well advanced. Policy relevant analyses are provided below. Relying on econometrics, further analyses could be conducted to, for instance, estimate the effect these types of support have on trade of environmentally-related goods.

\section{Main messages}

Estimates of global support to fossil fuels peaked in 2012 but has since declined, a trend driven by countries outside the OECD area where the slump in international oil prices decreased support linked to price controls, a prevalent policy instrument in these countries.

14 Sources are the combined IEA-OECD estimate of support to fossil fuels (OECD, 2018) and the Regulatory Indicators for Sustainable Energy (RISE) in Banerjee et al. (2017). See Annex A for full details.

15 See Annex A for a complete list of countries covered.

16 See Annex A for a complete list of countries covered. 
As of 2015, nearly all countries had encouraged the deployment of renewable energy, but OECD countries offered a significantly more favourable policy and regulatory environment than countries outside the OECD area.

Data suggest that a strong policy and regulatory environment that encourages the use of renewable energy is associated with an increase in the net exports of energy plant equipment in view of the improvement of the country's competitiveness in this sector.

\section{Policy context}

Increasing the share of renewable energy and reducing that of fossil fuels in the energy mix is a key condition to a low-carbon transition. The success of this transition will depend on a policy and regulatory environment that creates incentives to increase both public and private investments. Such a low-carbon transition is likely to stimulate international trade in environmental goods such as wind turbines, solar panels, equipment for hydropower generation, and energy-storage devices. Services such as performance monitoring and maintenance of renewable energy infrastructures are more likely to be internationally traded because of the widespread use of advanced information technologies in global value chains.

However, many OECD countries and partner economies support fossil fuels production through direct transfers or preferential tax treatments, thus hampering low-carbon transitions. Consumption of fossil fuels is also supported by regulated prices, direct transfers, consumer discounts on energy-product purchases, and targeted tax rebates. Two indicators are proposed to address this issue.

First, an indicator that reports the amount provided by governments to fossil fuel producers and consumers through direct transfers and revenue forgone. This can help assess the extent to which support for fossil fuels crowd-out investment in greener energy and decrease trade in related environmental goods.

Second, an indicator that measures how the policy and regulatory environment encourages the production and deployment of renewable energy. This indicator can help assess whether it is consistent with scaling-up investments necessary to a low-carbon transition. It can also help identify those sections of a legislation that appear to be hurdles to the expansion of renewable energy. Further quantitative analyses could estimate whether a strong policy and regulatory environment for renewables is associated with more trade in related environmental goods.

\section{Main trends}

\section{Support for fossil fuels and renewables: Where do we stand?}

Estimates of global support to fossil fuels peaked in 2012, totalling USD 620 billion, but declined in 2015 to USD 370 billion (Figure 21). While production support has remained relatively stable, a decomposition analysis of the change in consumer price support, i.e. government support provided through the under-pricing of fossil fuels, shows that $80 \%$ of the drop in total support between 2012 and 2015 was due to the slump in international oil prices. The remaining $20 \%$ can be attributed to domestic price reforms and other factors 
that contributed to the price-gap ${ }^{17}$ estimation of consumer price support: exchange rates, domestic fuel consumption, transport, and distribution costs. This trend is driven by countries outside the OECD area where price controls are a prevalent policy instrument. Conversely, the amount of support to fossil fuels in OECD countries has been relatively more stable over time and amounted to USD 100 billion in 2015, accounting for $27 \%$ of global support.

Between 2012 and 2015, support to petroleum decreased by USD 190 million $(-43 \%)$ and support to coal and gas decreased by USD 3 million (-17\%) and USD 51 million (-33\%) respectively (Figure 22). Petroleum still receives the most support, accounting for $72 \%$ on average of total support to fossil fuels between 2012 and 2015, due in part to its predominant use in transport. Shares for coal and natural gas accounted for $3 \%$ and $25 \%$ on average respectively.

Figure 21. Combined IEA-OECD estimate of support for fossil fuels

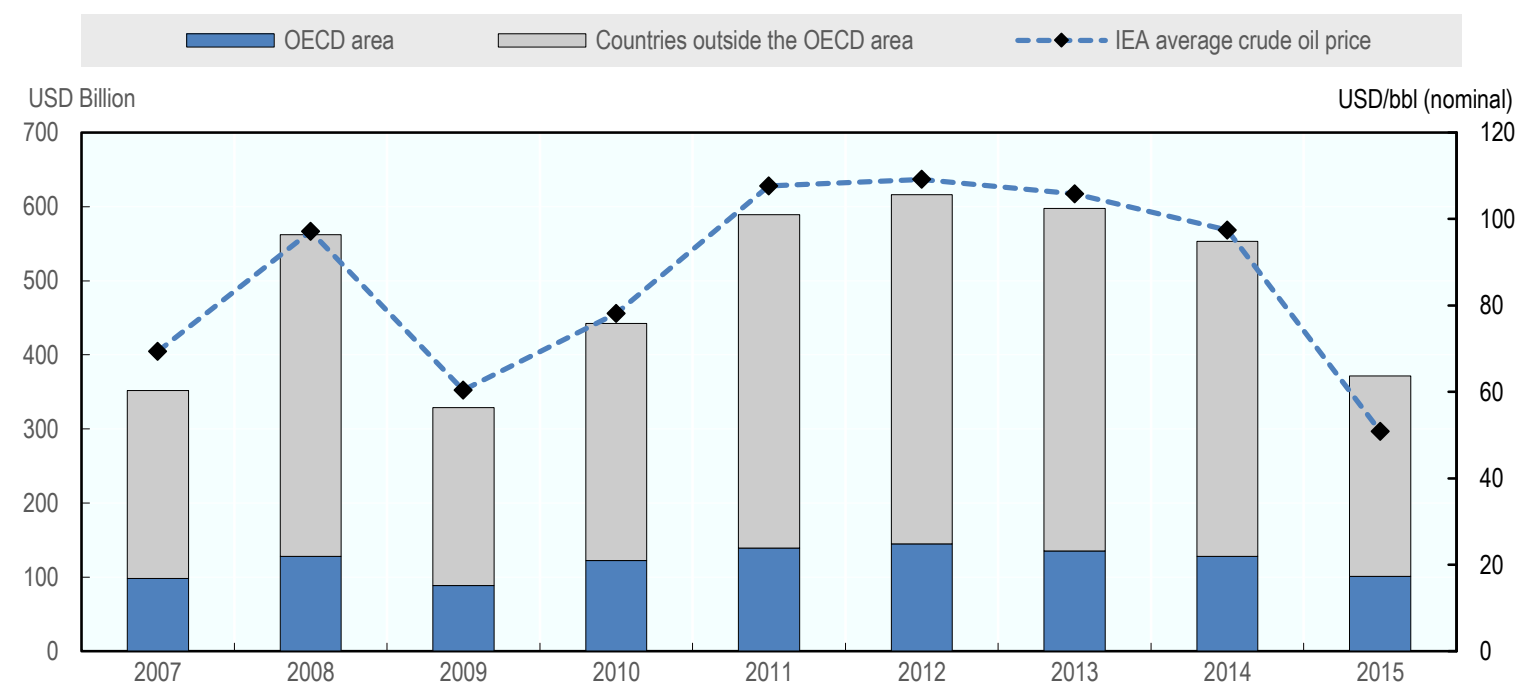

Source: Combined IEA-OECD estimate of support to fossil fuels (OECD, 2018). This indicator covers 76 countries that are accountable for $94 \%$ of global carbon emissions in 2015 .

17 The price-gap approach captures the "under-pricing" of fossil fuels on domestic markets by calculating the difference between international reference prices and (lower) observed domestic energy prices. This difference, financed by governments, is considered a support to fossil fuels. 
Figure 22. Combined IEA-OECD estimate of support by type of fuel

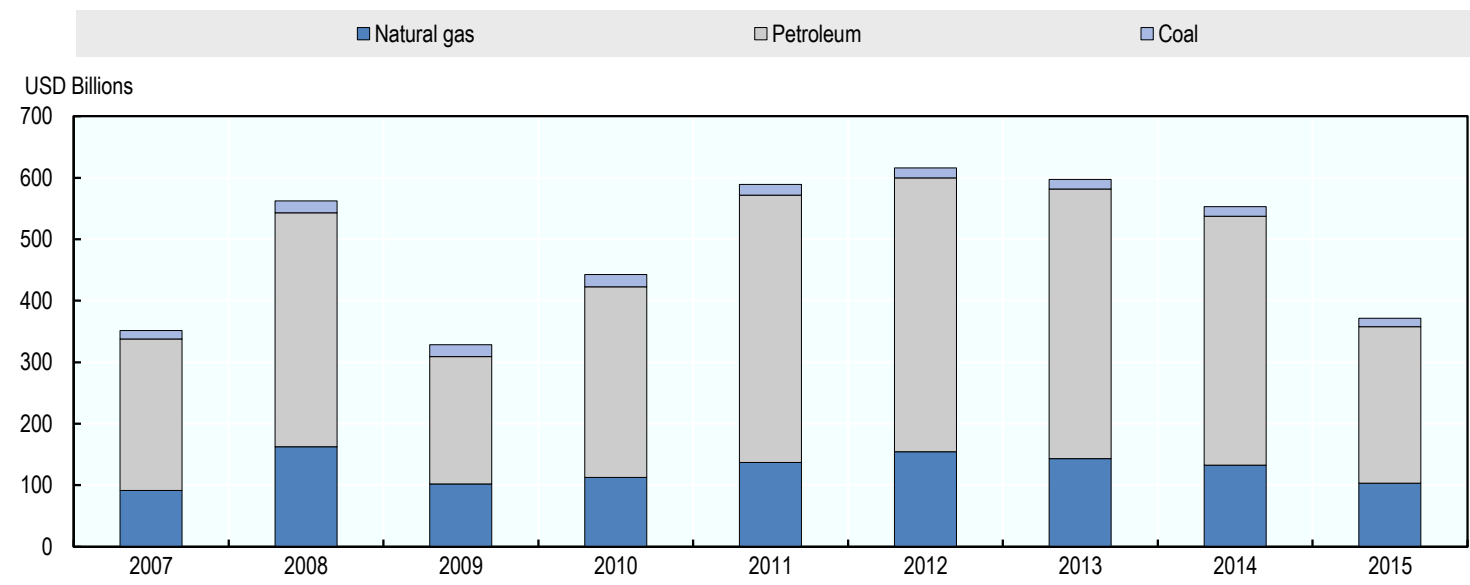

Source: Combined IEA-OECD estimate of support to fossil fuels (OECD, 2018). This indicator covers 76 countries that are accountable for $94 \%$ of global carbon emissions in 2015.

As of 2015, nearly all countries encouraged the production and consumption of renewable energy through a specific legal and regulatory framework, planning for renewable energy, and financial and regulatory incentives (e.g. feed-in tariffs or guaranteed access to the grid) (Figure 23). However, OECD countries offers a significantly more favourable policy environment for renewable energy than countries outside the OECD area. This results from the fact that nearly all OECD countries: (i) apply some form of carbon pricing policy that provides a relative advantage to zero-carbon energy sources; (ii) offer stronger financial and regulatory incentives through clear, predictable, and financially sustainable policies; ${ }^{18}$ and (iii) lower the risks and uncertainties related to investment in renewable energy markets. ${ }^{19}$

18 For instance, a defined market entry mechanisms for private renewable energy projects such as licensing. Another example are rules that govern the price level modification and frequency to ensure that developers know in advance the amount of money they will receive for power generation. See Banerjee et al (2017) for a complete discussion.

19 These risks and uncertainties relate more to utilities buying power than to private generators of renewable electricity. They can be mitigated by enhancing transparency on the credit worthiness of these utilities or through government guarantees of payments to generators. 
Figure 23. Enabling policy and regulatory environment for renewable energy by type of policies and areas (2015)

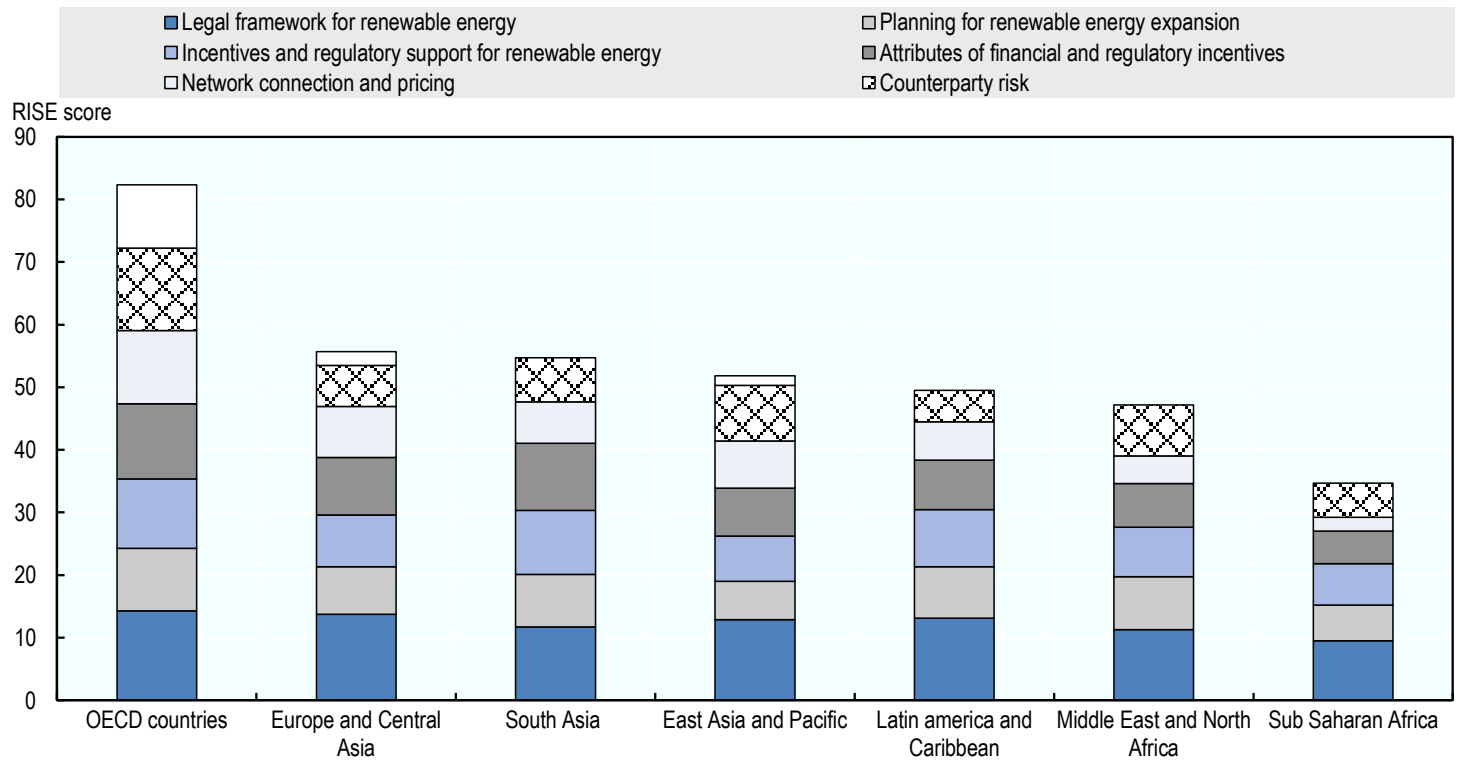

Note: Y-axis reports scores between 0 and 100 - where 100 implies the best performance - that capture the extent to which countries' policy and regulatory environment encourages renewable energy deployment in 2015. Legal framework for renewable energy measures the strength of the primary legislation for renewable generation and its business-friendliness. Planning for renewable energy expansion measures the ambition of renewable expansion through official targets and associated resources and through the availability of information that is necessary for developers. Incentives and regulatory support captures the government measures to improve the financial returns or reduce the risks of private projects through financial and fiscal incentives. Attributes of financial and regulatory incentives measures how incentives are clear, predictable, and financially sustainable. Network connection and use measures the quality of network connection and the adequacy of pricing. Counterparty risk of the energy firms assesses risks and uncertainties related to investments in renewable energy markets. Carbon pricing and monitoring measures the stringency of carbon pricing and the quality of the verification system for greenhouse gas emissions.

Source: Regulatory indicators for sustainable energy (RISE) in Banerjee et al (2017).

\section{Implications for trade}

Encouraging the deployment of renewables has an ambiguous effect on trade balances for environmental goods. On the one hand, a policy environment favourable to the deployment of renewable energy increases domestic demand for environmental goods, which can be met through an increase in imports if local firms cannot supply it. On the other hand, the same policy environment could create incentives to stimulate innovation in local firms improving the long-term competitiveness of related industries, thus potentially decreasing demand for imports and increasing exports. ${ }^{20}$ Therefore, countries providing strong support for renewables could help improve their trade balance related to these industries.

Data suggest that this effect does prevail and that an enabling policy and regulatory environment improves the country's competitiveness in the sector of renewable energy plants' equipment, as measured by the sector's net exports (Figure 24). This is consistent with recent empirical evidence putting forward that more-stringent environmental policies are associated with increased exports in environmental goods (Sauvage, 2014) and services (Sauvage and Timiliotis, 2017). Conversely, countries spending a larger share of their GDP

20 This is known as the Porter Hypothesis (Porter and Van Der Linde, 1995). 
to support fossil fuels seem to harm the competitiveness of their domestic industry producing renewable energy plant equipment, particularly in countries outside the OECD area (Figure 25).

Figure 24. Enabling policy and regulatory framework for renewable energy and net exports of renewable energy plants equipment (2015)
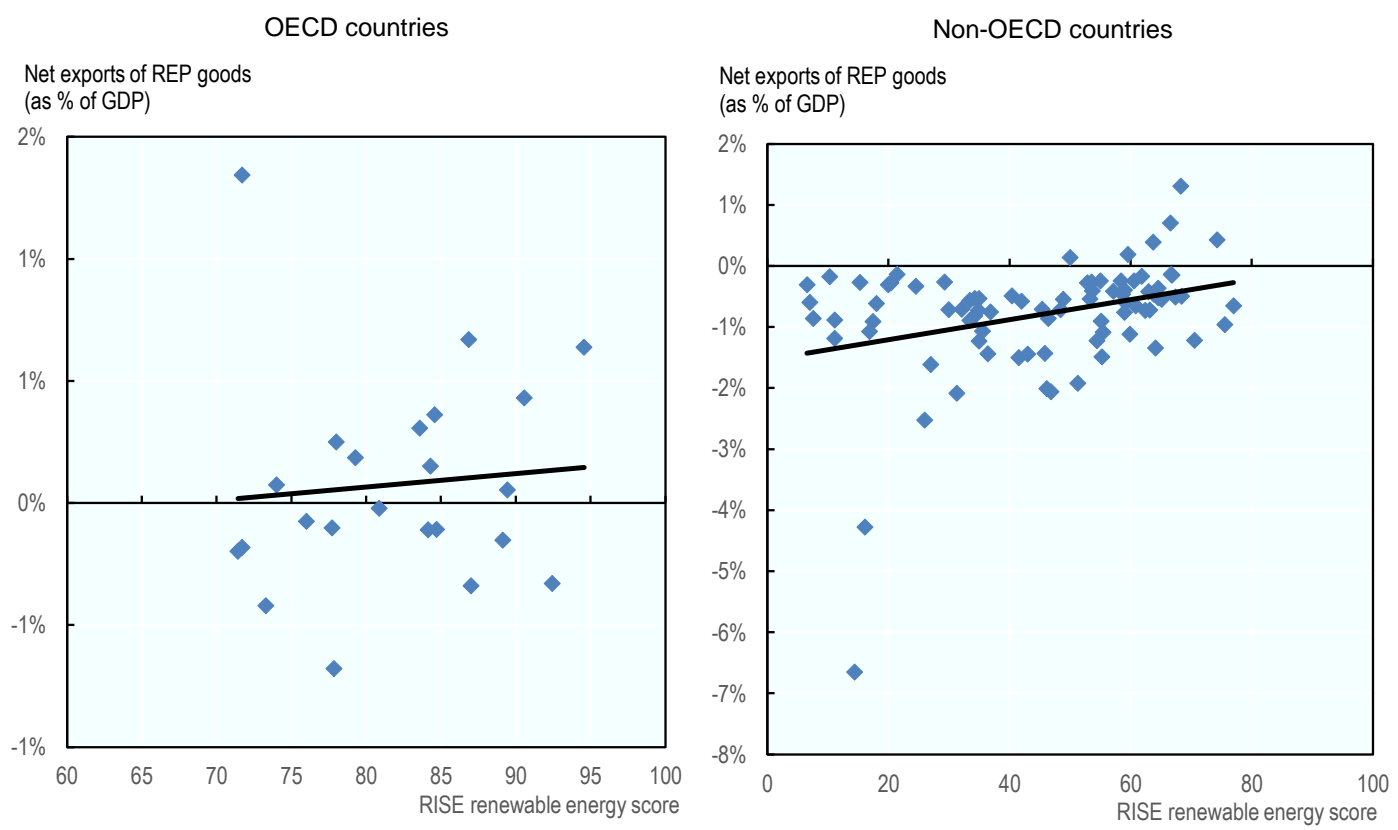

Source: Regulatory indicators for sustainable energy (RISE) in Banerjee et al. (2017) and BACI International Trade database. 
Figure 25. Support to fossil fuels and exports of net renewable energy plants equipment (2015)
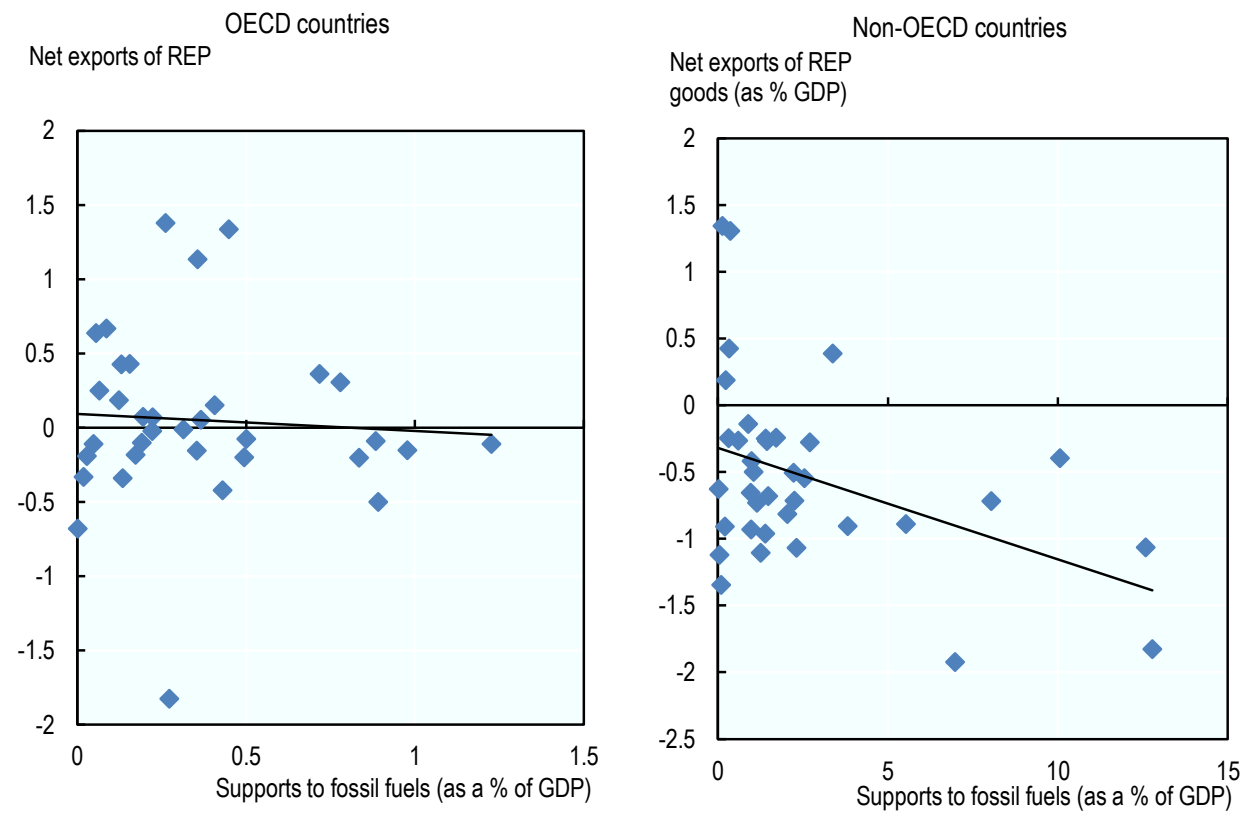

Source: Combined IEA-OECD estimate of support to fossil fuels (OECD, 2018) and BACI International Trade database.

The viability of these support measures depends largely on the associated trade distorting effects, which in practice are very different whether they target fossil fuels or renewables. Because the bulk of measures for fossil fuels support consumption - and are not "specific" to a certain industry or group of industries -, they are most likely to be trade facilitating in that they increase imports of fossil fuels (Steenblik, 2005; OECD, 2018). Therefore, they are unlikely to be challenged by trading partners (Meyer, 2017). By contrast, conditions tied to certain types of support to renewables such as local content requirements have been challenged at the WTO in recent years because of their trade distorting effects on imports from trading partners (Steenblik, Sauvage and Timiliotis, 2018).

\section{Trade in waste and scrap}

\section{Definition}

This indicator reports the amount of exports and imports of waste and scrap as defined in in Kellenberg (2012) in current USD and in kilograms for all countries between 2003 and $2016 .{ }^{21}$

21 Sources for this indicator is BACI International trade database and (Kellenberg, 2012[1]). See methodological note for full details. 


\section{State of the progress}

The development of this indicator is intermediate. It allows for some descriptive analyses, provided below. However, at this stage the relative importance of the different drivers of trade in waste and scrap - e.g. the value of secondary materials or the regulatory measures introduced by international conventions such as the Basel Convention - cannot be measured. Introducing this indicator in an econometric model (e.g. a gravity model) would allow for more insights on how these potential determinants would affect trade patterns in waste and scrap. In addition, since there is no consensus on which traded goods should be considered "waste" or "scrap", a refinement of this classification process would be a relevant next step to improve the quality of these indicators.

\section{Main messages}

Over the period 2003-2016, the value and weight of trade in waste and scrap increased by $181 \%$ and $47 \%$ respectively, meaning that, on average, the unit value of traded WS items has been rising over time.

Trade in waste and scrap involves a limited number of countries, with the top 20 exporters and importers accounting for $79 \%$ of total exports and $84 \%$ of total imports respectively.

A significant number of OECD countries are both large exporters and importers, while countries outside of the OECD area (such as China, India, Pakistan and Viet Nam) are mainly importers, and export very little waste and scrap.

Strict regulation on landfilling appears to be a driver of trade in waste and scrap as countries with the lowest shares of landfilled municipal solid waste are the largest exporters of paper, plastics, and textile waste.

\section{Policy context}

Cross-border movements of waste and scrap represent both an opportunity and a threat for the environment. On the one hand, trade can enable waste to be sent to countries that have comparative advantages in sorting and processing capabilities, including facilities with higher environmental standards for material and energy recovery. This can reduce the cost of waste treatment and recycling, which is beneficial to trading partners and leads to better environmental outcomes (OECD, 2018). Similarly, the substitution of primary raw materials with secondary raw materials (i.e. scrap) can help decouple raw material use from economic growth, the main goal of the so-called circular economy (Yamaguchi, 2018).

However, concerns regarding trade in waste and scrap arise if exports destinations lack an environmentally sound regulatory framework for waste management and the associated infrastructure capacities. Trade flows of waste destined to non-compliant waste-recovery facilities, landfills, or even open dumping will have an adverse effect on the environment. Trade in waste to countries outside the OECD area has recently intensified (Farrelly, Schneider and Stupples, 2016; Yanai, 2014) and this leads to the question of what the overall impact of this trend will be.

An indicator on the volume of trade in waste and scrap provides some insights on these questions. To better address the drivers of such trade, this indicator could be introduced along with policy variables in a gravity model to determine which regulations actually drive the different categories of waste and scrap into and out of countries. Such an approach would also enable to measure the role that trade restrictions play in this context, and to help 
determine whether they reduce the recovery or re-use of scrap materials in countries that do not have the recovery capacity or the demand for such materials.

\section{Main trends}

In 2016, global trade in waste and scrap ${ }^{22}$ was worth USD 94 billion and amounted to a total weight of 218 million tonnes (Figure 26 and Figure 27). The main traded categories of waste and scrap were metals, papers, and plastics, which together accounted for $97 \%$ and $94 \%$ of total value and total weight respectively.

Figure 26. Value of global trade in waste and scrap in USD billion (2003-2016)

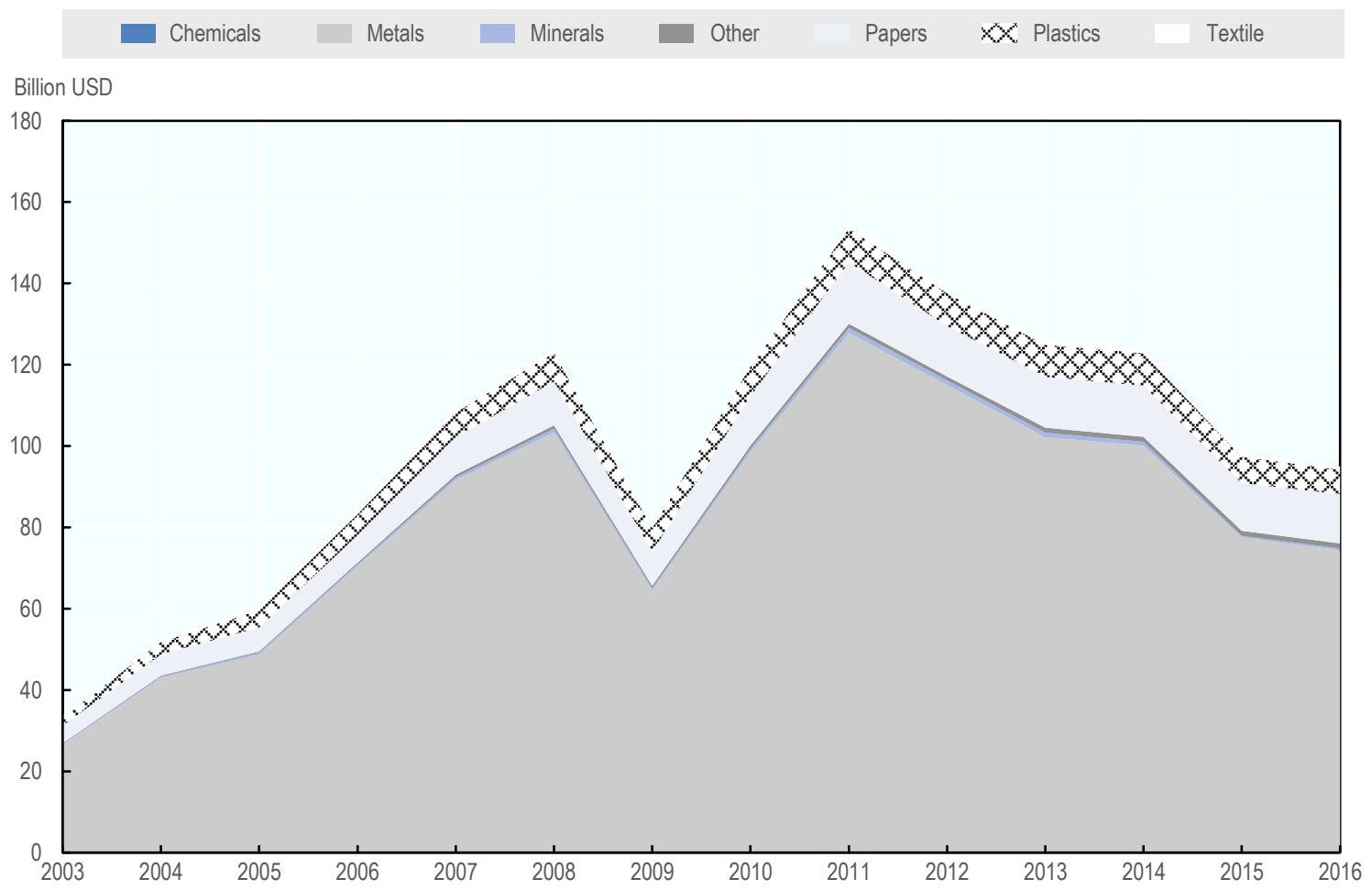

Note: Waste and scrap items are those contained in the list of 62 Harmonized System (HS) codes provided in Kellenberg (2012).

Source: BACI International Trade Database.

22 Waste and scrap items are defined following Kellenberg (2012), who considers all six-digit categories from the Harmonized System (HS) for which waste or scrap or both was the only categorisation of a product or material. This amounts to $62 \mathrm{HS}$ codes, which are listed in the appendix. 
Figure 27. Weight of global trade in waste and scrap in million tonnes (2003-2016)

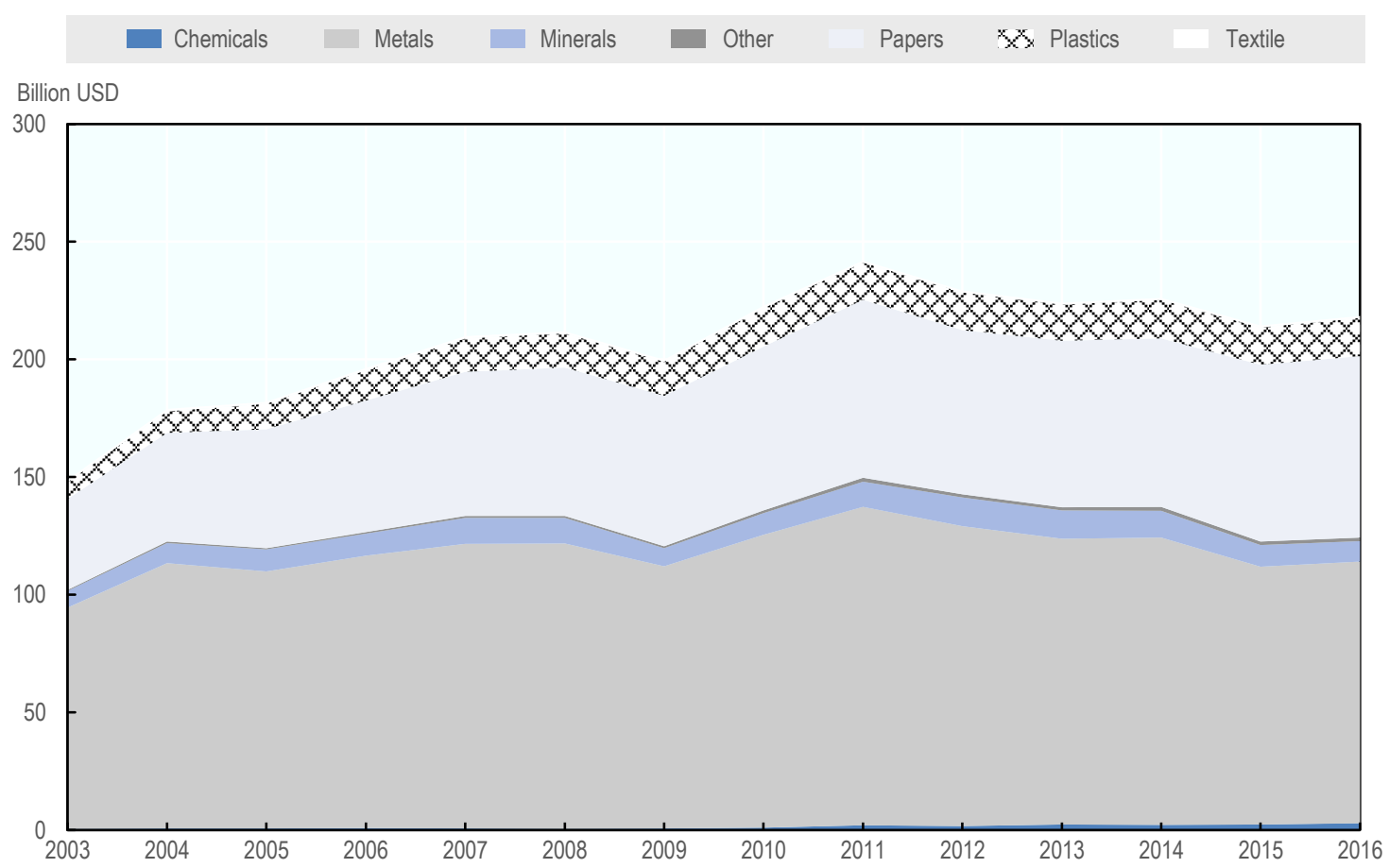

Note: Waste and scrap items are those contained in the list of 62 Harmonized System (HS) codes provided in Kellenberg (2012).

Source: BACI International Trade Database.

Over the period 2003-2016, the value of trade in waste and scrape increased by $181 \%$. Considering that the associated growth in weight over the same period was about $47 \%$, this trend suggests that, on average, the unit value of traded waste and scrap items has been rising over time. Categories of metals, papers, and plastics have had similar growth rates in value terms, but displayed different patterns in terms of weight $(100 \%$ and $123 \%$ for papers and plastics respectively, as opposed to $18 \%$ for metals).

Trade in waste and scrap involves a limited number of countries. In 2016, the top 20 exporters and importers accounted for $79 \%$ of total exports and $84 \%$ of total imports respectively (Figures 1.29 and 1.30). A significant number of OECD countries are both large exporters and importers, while countries outside the OECD area (such as China, India, Pakistan, and Viet Nam) are mainly importers and barely export waste and scrap.

Among those top players, the destinations of exports in WS are quite diversified (Figure 30). In 2016, the bulk of exports from EU countries and Switzerland ended up being shipped to other EU countries, China, and Turkey, in that order. Although the main destination of US exports of waste and scrap is China, NAFTA countries also appear to be strong trading partners in both exporting to and importing between countries. Japan exports waste and scrap primarily to Asian countries, in particular to China and Korea. 
Figure 28. Top 20 exporters of waste and scrap (by share of global WS trade in 2016)

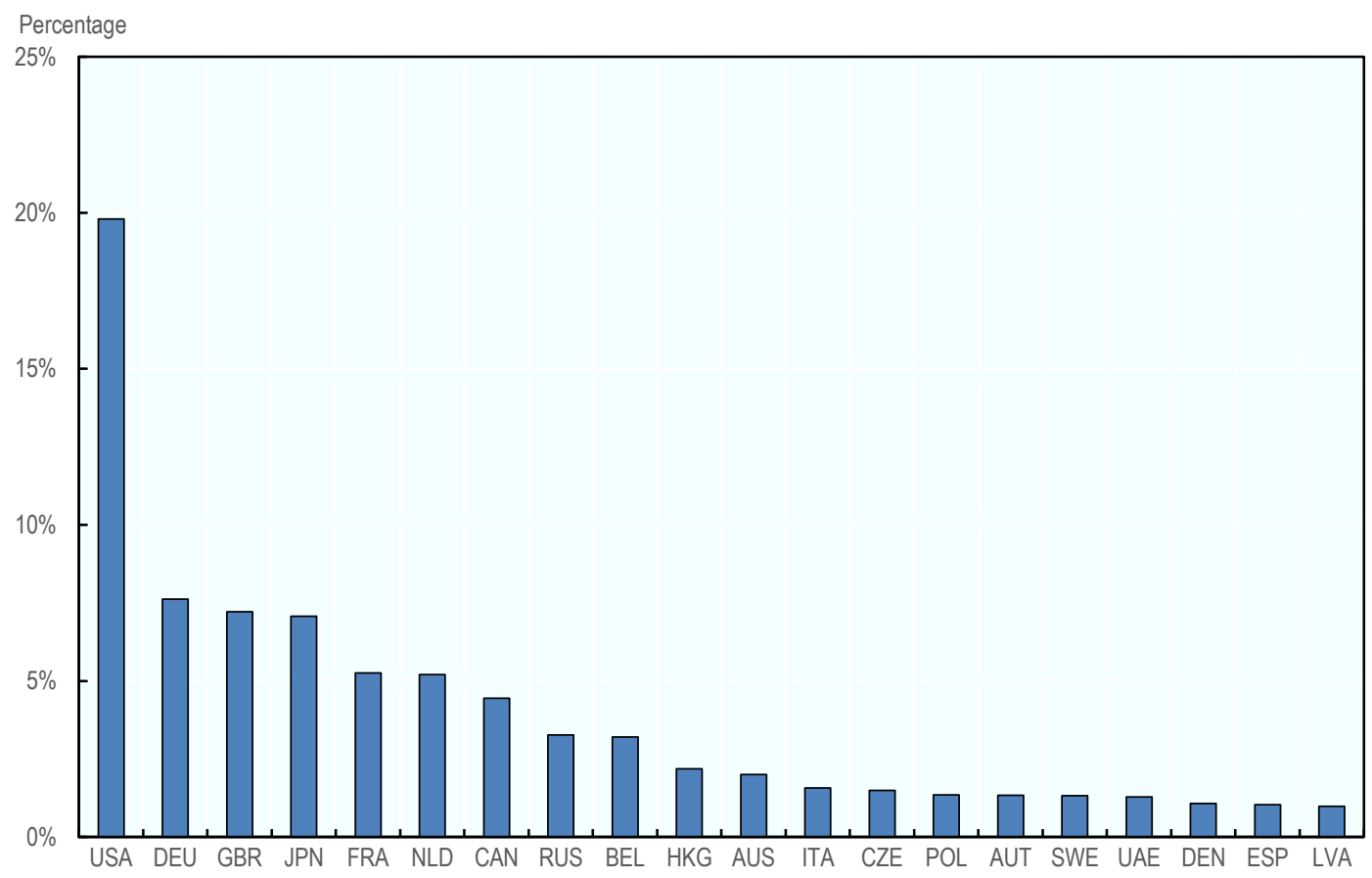

Note: Waste and scrap items are those contained in the list of 62 Harmonized System (HS) codes provided in Kellenberg (2012). Source: BACI International Trade Database.

Figure 29. Top 20 importers of waste and scrap (by share of global WS trade in 2016)

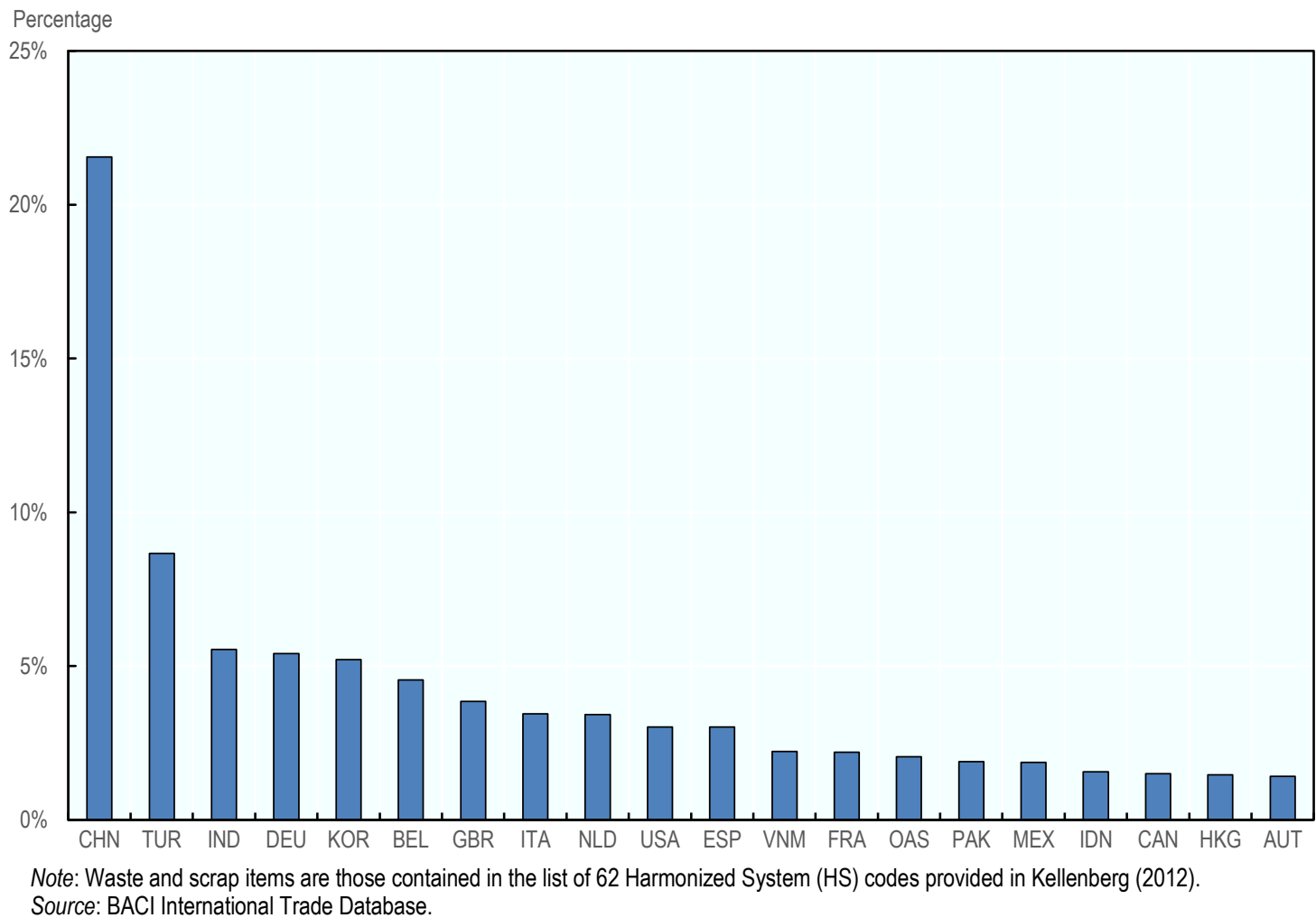


Figure 30. The diversification of trade in waste and scrap exports destinations

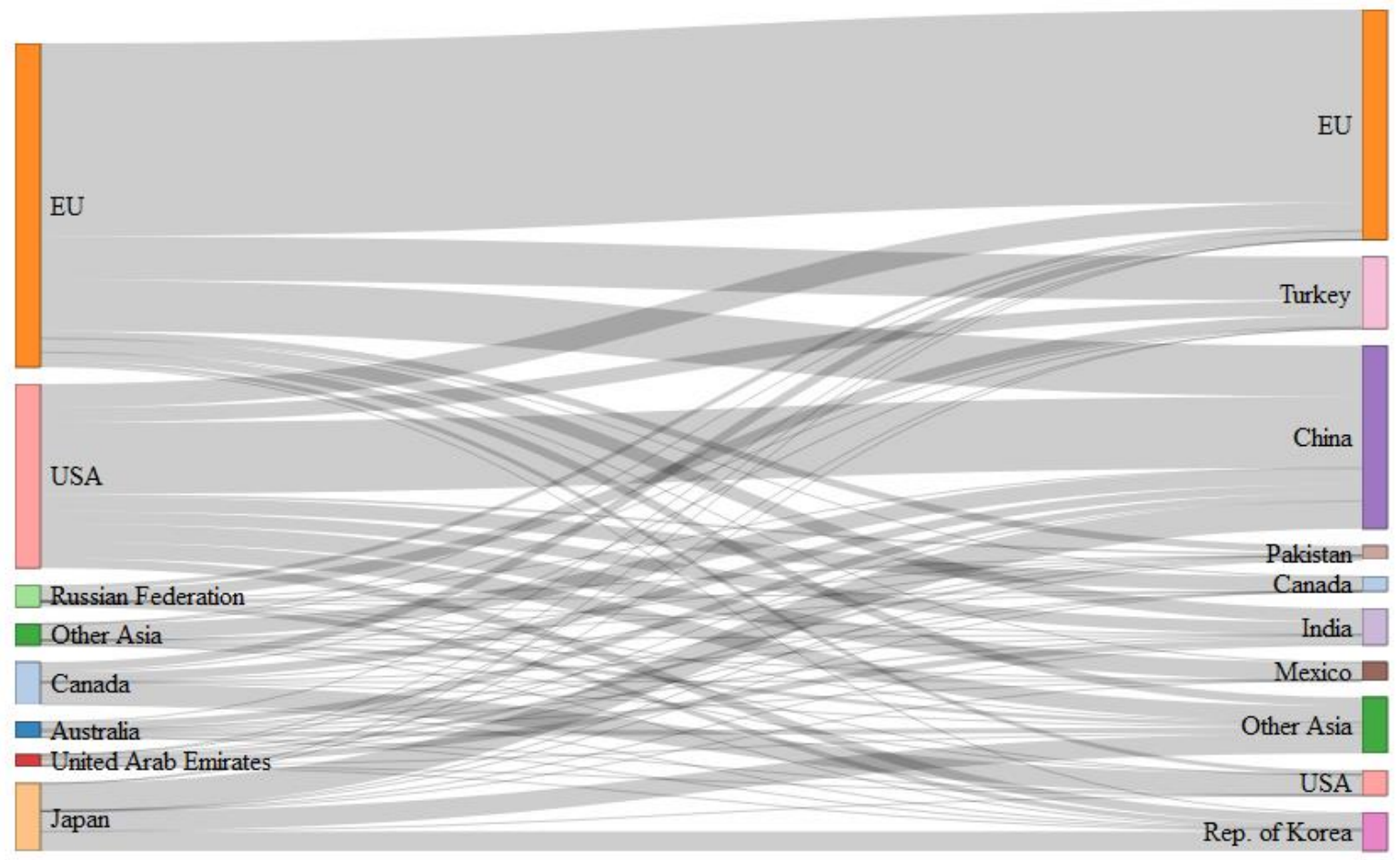

Note: Traded weight of waste and scrap items from countries of origins (left-hand side) to countries of destinations (right-hand side) in 2016. Waste and scrap items are those contained in the list of 62 Harmonized System (HS) codes provided in Kellenberg (2012).

Source: BACI International Trade Database.

Finally, data suggest that the lower the share of municipal solid waste (MSW) that is landfilled, the larger the exports' volume of papers, plastics, and textiles waste (Figure 3). However, results from Sauvage (2014) show that the more stringent the regulation of the MSW management sector, the stronger the trade comparative advantage in environmental goods related to solid waste management. This lends support to the argument that a demand for these goods is created as a result of associated stricter environmental standards. An explanation to this apparent contradiction is that countries with stricter regulation on landfilling may reprocess only the highest-quality part of their waste - e.g. the best sorted bales - and ship the rest to other countries such as China (The Economist, 2018). ${ }^{23}$

23 China has recently made three notifications to the WTO's Committee on Technical Barriers to Trade relating to imports of solid waste or secondary materials. The first was made in July 2017 and established a list of 24 solid wastes items to be prohibited for import. The second, made in November 2017, set a maximum level of contamination for 11 items. In April 2018, China announced additional import prohibitions on a further 32 categories of solid waste (including plastic waste and scrap from industrial sources) to take effect in December 2019 at the latest (BIR, 2018). The justification for these regulations was the protection of the environment and of human health (WTO, 2017). However, thresholds for carried waste included in imports of recyclable and scrap products are much more stringent than China's own domestic requirements, which may constitute a form of trade discrimination. 
Figure 31. The share of municipal solid waste landfilled as a driver of trade in waste and scrap (2016)

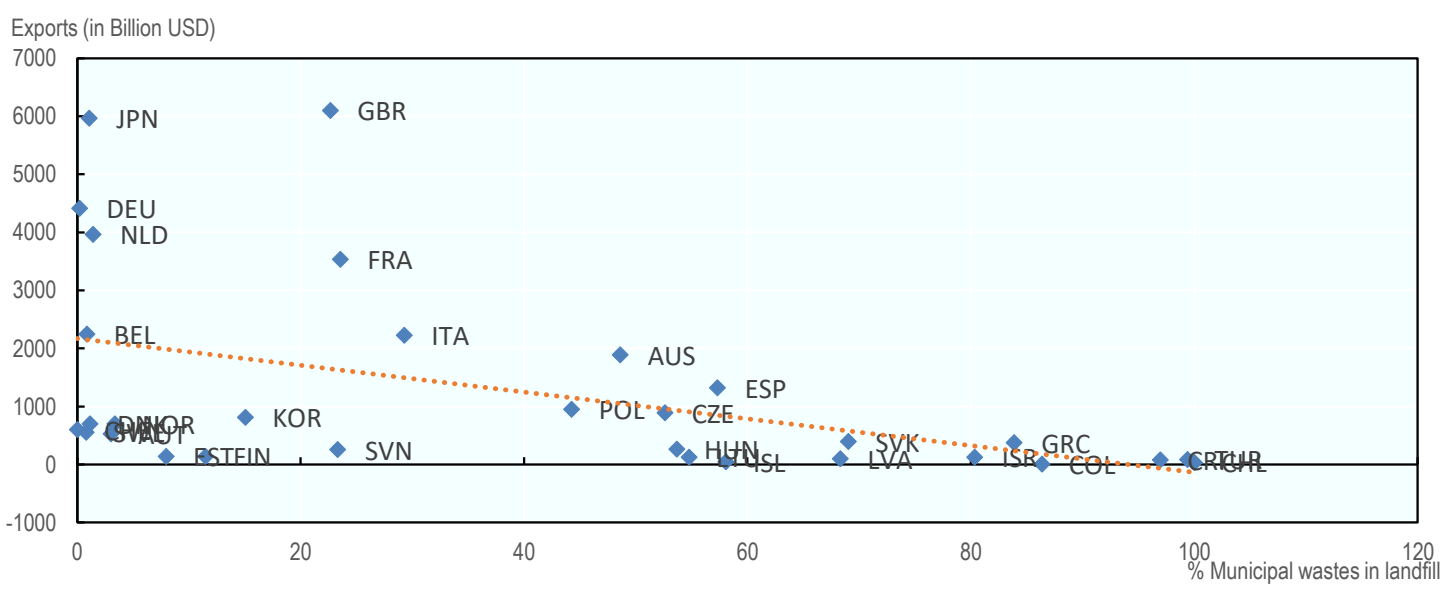

Note: Exports of papers, plastics and textiles in 2016

Source: BACI International Trade Database and OECD Green Growth Indicators.

\section{Nutrient balances of exported grains}

\section{Definition of the indicator}

The indicator reports the nutrient balance - the difference between the quantity of nutrient of $\mathrm{N}$ and $\mathrm{P}$ inputs entering an agricultural system and the quantity of nutrient outputs leaving this system - for exports of nine cereals and oilseed ${ }^{24}$ as a share of the total nutrient balance in 21 OECD countries ${ }^{25}$ between 2006 and 2014. ${ }^{26} 27$

\section{State of the progress of the indicator}

The development of this indicator is intermediate. Expanding the time and country coverage would be relevant next steps. In addition, it would be useful to refer to a tradeopenness index that could explore whether trade liberalisation resulted in the basket of grains for exports to differ from the basket of grains for domestic consumption, thereby resulting in different nutrient balances and potentially different environmental pressure.

24 These are wheat, maize, oats, sorghum, barley, soybeans, rapeseeds, sunflower seeds, and rice.

25 Countries and years of study were selected according to data availability.

26 See methodological note for a complete list of countries covered by this indicator.

27 Sources for this indicator are data are compiled from the International Fertilizer Association (IFA), the FAO, the OECD, Eurostat and, BACI International Trade database. See methodological note for full details. 


\section{Main messages}

The nutrient surpluses for both nitrogen and phosphorous that are associated with the production of exported grains from OECD countries declined between 2006 and 2014, while the volume of exported grains increased. This suggests that a growing percentage of global demand for grains is decoupled from nutrient surpluses.

Several countries, however, export grains that disproportionately contribute to both nitrogen and phosphorous nutrient surpluses of total production.

One explanation is that rising global demand for grains leads these countries to increase nutrient-related environmental pressure. Policy measures that provide incentives to reduce overuse of nutrients would address this effect without imposing trade barriers, and could improve both productivity and sustainability in these countries.

\section{Policy context}

Inputs of nutrients, specifically nitrogen $(\mathrm{N})$ and phosphorus $(\mathrm{P})$, are essential in the production of grains and important determinants of agricultural yields. However, an excess of nutrients - beyond plants' needs - represents not only a possible cause of economic inefficiency, but a source of potential harm to the environment. The excess nutrients can generate water eutrophication and contamination, air pollution by ammonia and greenhouse gas emission. At the global scale, the use of $\mathrm{N}$ and $\mathrm{P}$ in agriculture is so large that they significantly perturb the natural cycles of these elements ( (Rockström et al., 2009 $9_{[2]}$ ), (Dao, Peduzzi and Friot, 2018[3])).

Responding to global demand, the basket of grains dedicated to exports may differ from the basket of grains for domestic consumption, resulting in different nutrient balances - the difference between the quantity of nutrient inputs entering an agricultural system and the quantity of nutrient outputs leaving this system. The relative importance of the basket of exported grains in the domestic nutrient balance is ambiguous. On the one hand, export driven choices can lead to a reallocation of resources to, for instance, crops that are less efficient in converting nutrient inputs or to an expansion of land use to less productive plots. Both result in a more intensive use of inputs and more surplus of nutrients. On the other hand, grains for export can lead to production that is less input-intensive than domestic consumption. For instance, leguminous plants grown for export because of their capacity to fixate nitrogen (i.e. convert nitrogen from the atmosphere into ammonia) may, in some cases, compensate partially for the nutrient surpluses of other crops.

\section{Main trends}

The nutrient balance associated with the production of exported grains from OECD countries $^{28}$ has remained positive, but declined between 2006 and 2014 for both nitrogen and phosphorous (Figure 33). This downward trend occurred while the volume of exported grains increased $(+17 \%)$, suggesting that a growing global demand for grains is decoupled from nutrient surpluses. ${ }^{29}$ Part of this improvement has resulted from the adoption of better nutrient management practices encouraged by extensive agro-environmental measures

28 Austria, Canada, Czech Republic, Denmark, Estonia, Finland, France, Germany, Greece, Hungary, Ireland, Italy, Japan, Latvia, Lithuania, Mexico, Poland, Portugal, Spain, the United Kingdom, and the United States.

29 This indicator shows that the nitrogen balance by unit of land decrease by $50 \%$ between 2006 and 2014 for total production. Phosphorous surplus by unit of land decrease by one-third. 
across countries (OECD, 2013). These practices include the optimisation of nutrient use by integrating soil quality and other environmental factors, or sowing leguminous as intermediate crops between two harvests to fix nitrogen from the atmosphere and decrease the need for chemical nutrients.

Figure 32. Nutrient balances of exported grains from OECD countries (2006-2014)

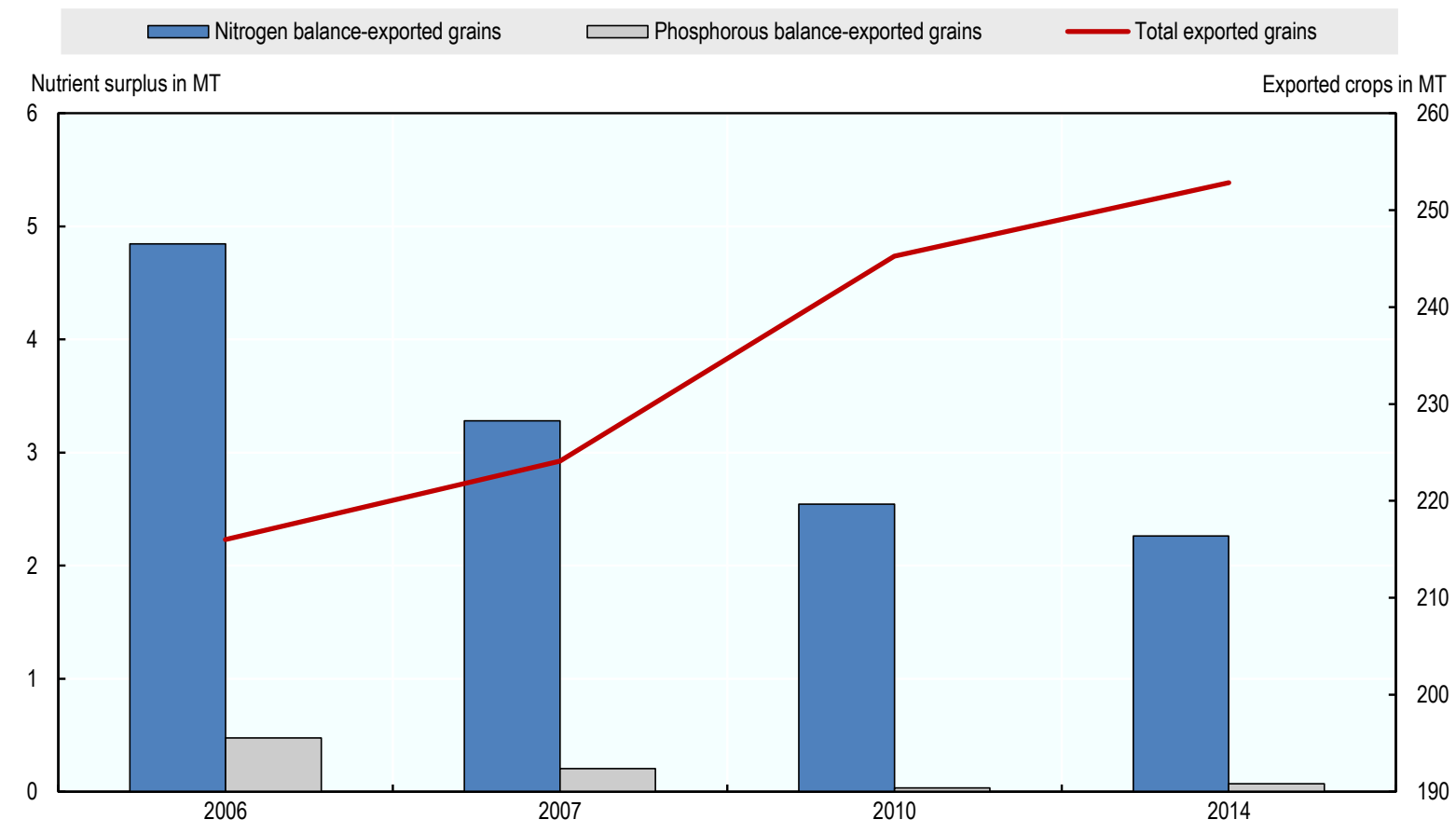

Source: Author's elaboration. Nutrient inputs and outputs data are compiled from the International Fertilizer Association (IFA), the FAO, the OECD and, Eurostat; exports data are from BACI International Trade Database.

At the same time, the nutrient balance of exported grains varies by country. In most cases, exported grains contribute to total nutrient balances as much as they contribute to total domestic production (Figure 33). However, some countries (Portugal, Denmark, and Latvia) export grains that disproportionately contribute to both nitrogen and phosphorous nutrient balances of total production. The share of nutrient balance for exported grains (out of the nutrient balance for total crop production) is larger for the United Kingdom, Italy, France, Greece, Poland, Australia, Estonia, and Lithuania than the share of exported grains (out of the total crop production in volume) for one nutrient - nitrogen or phosphorous. The remaining countries export grains that contribute less-than-proportionally to the overall nutrient balances.

Such variations can be explained by differences in grain choices and specialisation patterns. For instance, the relative high $\mathrm{N}$ surplus in Austria's exported grains is explained by wheat - a crop with high $\mathrm{N}$ requirements - which amounts to 58\% of exported grains and only $33 \%$ of production. Italy's grain exports have a high phosphorous surplus relative to the phosphorous balance of its domestic production because of the importance of rice, which amounted to $64 \%$ of exported grain volume in 2014 but only $7 \%$ of total domestic production, while having a high $\mathrm{P}$ surplus In the few countries that have exported grains 
with higher-than-domestic-production nutrient balances (in particular P balance), it seems the response to global demand leads such countries to increase nutrient-related environmental pressure. Policy measures providing incentives to reduce the overuse of $\mathrm{P}$, if effective, would address this effect and improve both productivity and sustainability in such countries.

Figure 33. Nutrient balances and volume of exported grains as shares of domestic nutrient balance and share of production volume - 2014

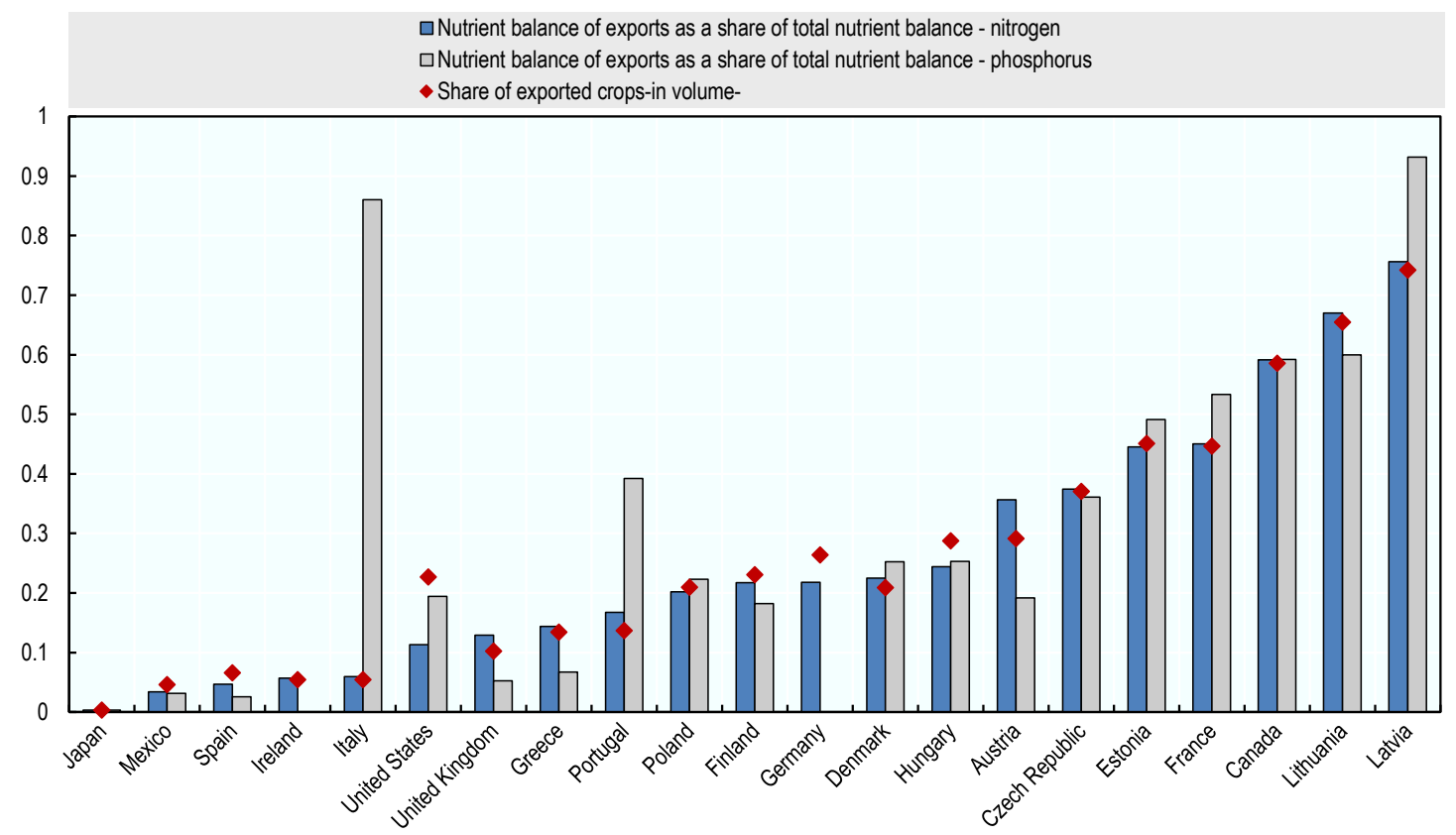

Note: If the share of the nutrient balance for exports (blue and grey bars for nitrogen and phosphorous respectively) is larger than the share of exported grains (red dot), it means that exported grains are overusing nutrients more than the total production on average. For instance, the nitrogen balance of exported grains in Denmark accounts for $22 \%$ of the overall nitrogen balance of the country, whereas $21 \%$ of the volume of grains is exported, showing that exported grains are proportionally overusing more nitrogen compared to grains for domestic consumption.

Source: Author's elaboration. Nutrient inputs and outputs data are compiled from the International Fertilizer Association (IFA), the FAO, the OECD and, Eurostat; exports data are BACI International Trade database. 


\section{References}

Banerjee, S. et al. (2017), Regulatory indicators for sustainable energy : a global scorecard for policy makers (English)., World Bank Group,

http://documents.worldbank.org/curated/en/538181487106403375/pdf/112828-REVISED-PUBLIC-RISE-2016Report.pdf.

BIR (2018), "China: additional import prohibitions for 32 types of solid wast"e, http://www.bir.org/newspress/latest-news/china-additional-import-prohibitions-for-32-types-of-solid-waste/.

Bringezu, S. (2015), "Possible target corridor for sustainable use of global material resources." Resources 4.1, pp. 25-54.

Dao, Q., Peduzzi, P., and Friot, D. (2018), "National environmental limits and footprints based on the planetary boundaries framework: The case of Switzerland", Global Environmental Change, Vol. 52, 49-57. doi:10.1016/j.gloenvcha.2018.06.005

Economist (2018), "Exit the dragon”, 29 September, pp. 7-8.

Eurostat/OECD (2013), Methodology and Handbook: Eurostat/OECD Nutrient Budgets, http://epp.eurostat.ec.europa.eu (accessed on 17 September 2018).

Farrelly, T., P. Schneider and P. Stupples (2016), "Trading in waste: Integrating sustainable development goals and environmental policies in trade negotiations toward enhanced solid waste management in Pacific Islands countries and territories”, Asia Pacific Viewpoint, Vol. 57/1, pp. 27-43, http://dx.doi.org/10.1111/apv.12110.

Garsous, G. and T. Kozluk (2017), "Foreign Direct Investment and The Pollution Haven Hypothesis: Evidence from Listed Firms", OECD Economics Department Working Papers, No. 1379, OECD Publishing, Paris, http://dx.doi.org/10.1787/1e8c0031-en.

Gaulier, G. and S. Zignago (2010), "BACI: International Trade Database at the Product-level, The 19942007 Version”, CEPII Working Paper, No. 2010-23, CEPII.

International Energy Agency (IEA) (2018), CO2 Emissions from Fuel Combustion, http://data.iea.org//payment/products/115-co2-emissions-from-fuel-combustion-2018-edition-coming-soon.aspx (accessed 4 September 2018)

International Energy Agency (IEA) (2018), Electricity Information 2018, IEA, Paris, http://dx.doi.org/10.1787/electricity-2018-en.

A (2016), World Energy Outlook 2016, IEA, Paris, http://dx.doi.org/10.1787/weo-2016-en.

Kellenberg, D. (2012), "Trading wastes", Journal of Environmental Economics and Management, Vol. 64/1, pp. 68-87, http://dx.doi.org/10.1016/J.JEEM.2012.02.003.

Korinek, J. (2018), "Trade restrictions on metals and minerals", Chatham House, https://resourcetrade.earth/stories/trade-restrictions-on-metals-and-minerals (accessed on 26 July 2018).

Koźluk, T. and C. Timiliotis (2016), "Do environmental policies affect global value chains?: A new perspective on the pollution haven hypothesis", OECD Economics Department Working Papers, No. 1282, OECD Publishing, Paris, http://dx.doi.org/10.1787/5jm2hh7nf3wd-en.

Krugman, P. (1980), "Scale Economies, Product Differentiation, and the Pattern of Trade", The American Economic Review, Vol. 70/5, pp. 950-959, http://dx.doi.org/10.2307/1805774. 
Lenzen, M. et al. (2013), "EORA: A Global Multi-Region Input-Output Database at High Country And Sector Resolution", Economic Systems Research, Vol. 25/1, pp. 20-49, http://dx.doi.org/10.1080/09535314.2013.769938.

Levinson, A. (2009), "Technology, International Trade, and Pollution from US Manufacturing", American Economic Review, Vol. 99/5, pp. 2177-2192, http://dx.doi.org/10.1257/aer.99.5.2177.

Meyer, T. (2017), "Explaining energy disputes at the World Trade Organization," International Environmental Agreements: Politics, Law and Economics, Springer, Vol. 17(3), pp. 391-410, June

OECD (2018), OECD Companion to the Inventory of Support Measures for Fossil Fuels 2018, https://www.oecd.org/tax/oecd-companion-to-the-inventory-of-support-measures-for-fossil-fuels-20189789264286061-en.htm (accessed on 16 July 2018).

OECD (2018), Improving Markets for Recycled Plastics Trends: Prospects and Policy Responses, https://www.oecd-ilibrary.org/docserver/9789264301016en.pdf?expires $=1530710219 \& \mathrm{id}=\mathrm{id} \&$ accname $=0$ cid84004878 \& checksum $=4$ AE3D18F39C8079A7DBD20A34 BD50C2E (accessed on 04 July 2018).

OECD (2017), "Using the OECD Inter-Country Input-Output database to calculate demand-based material flows: An Empirical Assessment", OECD internal document.

OECD (2017), "Making trade work for all”, OECD Trade Policy Papers, No. 202, OECD Publishing, Paris, http://dx.doi.org/10.1787/6e27effd-en.

OECD (2015), OECD Companion to the Inventory of Support Measures for Fossil Fuels 2015, OECD Publishing, Paris, https://doi.org/10.1787/9789264239616-en.

OECD (2013), OECD Compendium of Agri-environmental Indicators, OECD Publishing, Paris, http://dx.doi.org/10.1787/9789264186217-en.

OECD (2012), OECD Environmental Outlook to 2050: The Consequences of Inaction, OECD Publishing, Paris, http://dx.doi.org/10.1787/9789264122246-en.

OECD (2010), "Towards a plurilateral agreement to liberalize international trade in environmental goods and services", Mimeo.

OECD/Eurostat (1999), The Environmental Goods and Services Industry: Manual for Data Collection and Analysis, OECD Publishing, Paris, https://doi.org/10.1787/9789264173651-en.

Porter, M. and C. Van Der Linde (1995), "Toward a New Conception of the EnvironmentCompetitiveness Relationship", The Journal of Economic Perspectives, Vol. 9/4, pp. 97-118, http://www.jstor.org/stable/2138392 (accessed on 12 October 2017).

Rockström, J. et al. (2009), “A safe operating space for humanity”, Nature, Vol. 461(7263), p.472.

Sauvage, J. (2014), "The Stringency of Environmental Regulations and Trade in Environmental Goods", OECD Trade and Environment Working Papers, No. 2014/03, OECD Publishing, Paris, https://www.oecd-ilibrary.org/trade/the-stringency-of-environmental-regulations-and-trade-in-environmentalgoods 5 jxrjn 7 xsnmq-en (accessed on 23 July 2018).

Sauvage, J. (2014), "The Stringency of Environmental Regulations and Trade in Environmental Goods", OECD Trade and Environment Working Papers, No. 2014/3, OECD Publishing, Paris, http://dx.doi.org/10.1787/5jxrjn7xsnmq-en.

Sauvage, J. and C. Timiliotis (2017), "Trade in services related to the environment", OECD Trade and Environment Working Papers, No. 2017/2, OECD Publishing, Paris, http://dx.doi.org/10.1787/dc99bf2ben. 
Steenblik, R., Sauvage, J., \& Timiliotis, C. (2018), "Fossil Fuel Subsidies and the Global Trade Regime", in H. Van Asselt (Author) \& J. Skovgaard (Ed.), The Politics of Fossil Fuel Subsidies and their Reform, Cambridge: Cambridge University Press, pp. 121-139, doi:10.1017/9781108241946.009.

Steenblik, R. (2005), "Liberalising Trade in 'Environmental Goods': Some Practical Considerations", OECD Trade and Environment Working Papers, No. 2005/5, OECD Publishing, Paris, http://dx.doi.org/10.1787/888676434604.

UNEP International Resource Panel (2016), Global Material Flows and Resource Productivity Assessment Report for the UNEP International Resource Panel, UNEP, http://wedocs.unep.org/bitstream/handle/20.500.11822/21557/global_material_flows_full_report_english.pdf?se quence $=1 \&$ is Allowed $=y$ (accessed on 10 July 2018).

Yamaguchi, S. (2018), "International Trade and the Transition to a More Resource Efficient and Circular Economy: A Concept Paper", Trade and Environment Working Papers, https://doi.org/10.1787/18166881.

Yanai, A. (2014), "Environmental provisions in Japanese regional trade agreements with developing countries", IDE Discussion Paper, http://hdl.handle.net/2344/1315 (accessed on 4 July 2018).

United Nations Statistics Division (2017), Correlation and conversion tables used in UN Comtrade, United Nations, New York, https://unstats.un.org/unsd/trade/classifications/corrnotes/HS2017\%20conversion\%20to\%20earlier\%20HS\%20versions\%20and\%20other\%20classifications.pdf (accessed on 17 January 2018).

Wiebe, K. and N. Yamano (2016), "Estimating CO2 Emissions Embodied in Final Demand and Trade Using the OECD ICIO 2015: Methodology and Results", OECD Science, Technology and Industry Working Papers, No. 2016/5, OECD Publishing, Paris, http://dx.doi.org/10.1787/5jlrcm216xkl-en.

Wiedmann, T. et al. (2015), "The material footprint of nations.", Proceedings of the National Academy of Sciences of the United States of America, Vol. 112/20, pp. 6271-6, http://dx.doi.org/10.1073/pnas.1220362110.

WTO (2017), "China WTO notification G/TBT/N/CHN/1211", https://docs.wto.org/dol2fe/Pages/FE_Search/FE_S_S009DP.aspx?language $=\mathrm{E} \&$ CatalogueIdList $=237688 \&$ CurrentCatalogueIdInde $=0 \&$ FullTextHash $=371857150 \& H a$ sEnglishRecord=True\&HasFrenchRecord=True\&HasSpanishReco.

WTO (2009), "Communication under paragraph 31 (III) of the Doha Ministerial Declaration", http://www.nerpor.pt/component/phocadownload/category/2-nerpor?download=17:friends-list-2009. 


\section{Annex A. Methodological Notes}

\section{A1. Three indicators on carbon emissions embodied in trade}

\section{Carbon emissions embodied in trade}

\section{Definition}

This indicator reports the amount of carbon emissions from fossil fuel combustion embodied in imports and exports in mega tonnes of $\mathrm{CO}_{2}\left(\mathrm{MtCO}_{2}\right)$ for 63 countries ${ }^{30}$ (and the Rest of the world) and 34 industries between 1995 and 2011. The variables included in the indicator dataset are the following:

- Country name.

- ISO code of the country.

- Industry code in the 2016 OECD Inter-Country Input Output (ICIO) framework. Definitions and equivalences with the International Standard Industrial Classification of All Economic Activities Revision 3 (ISIC Rev. 3) can be found in Appendix 1.B.

- Year the data on carbon emissions was recorded.

- Imported emissions: The amount of carbon emissions from fossil fuel combustion, associated with the final consumption in a given industry in a given country but that are generated in other countries (in $\mathrm{MtCO}_{2}$ ).

- Exported emissions: The amount of carbon emissions from fossil fuel combustion associated with the final consumption in other countries but that are generated by a given industry in a given country (in $\mathrm{MtCO}_{2}$ ) before export.

- Consumption-based emissions: The total amount of carbon emissions from fossil fuel combustion that is associated with the final consumption of a given industry in a given country, both domestically generated and imported (in $\mathrm{MtCO}_{2}$ ).

- Production-based emissions: The total amount of carbon emissions from fossil fuel combustion that is generated by a given industry in a given country and which is associated with both domestic and foreign final demands (in $\mathrm{MtCO}_{2}$ ).

At the country level (i.e. aggregating all industries for a given country), these variables are linked as follows:

consumption-based emissions $=$

- all emissions generated domestically (production-based emissions)

- minus emissions domestically generated for goods eventually consumed in other countries (exported emissions

- plus emissions generated elsewhere for goods consumed domestically (imported emissions).

30 Full list of countries provided in this Annex. 


\section{Sources, concepts, interpretation and limitations}

This indicator provides the total amount of carbon emissions from fossil fuel combustion embedded in the final consumption of a given industry in a given country, the so-called consumption-based emissions or carbon footprint. In other words, it provides the amount of emissions, generated both domestically and in foreign countries, that is associated with final domestic demand, i.e. final consumption from households, non-profit institutions and government, gross fixed capital formation, changes in inventories, and direct purchases abroad by residents (Wiebe and Yamano, 2016).

Such estimates decompose the global value chain of a country/industry's final demand and assigns the amount of emissions generated in each production segment to this country/industry (where the final product is eventually consumed). This indicator traces the entire value chain of traded products for final consumption back to all original sources of fuel combustion, and calculates the upstream amount of emissions that were generated domestically as well as in foreign countries. Embedded emissions in imports and exports, also provided by the indicator, can thus be used to measure embodied emissions in trade.

This indicator is constructed following the methodology of Wiebe and Yamano (2016), which uses the 2016 OECD Inter-Country Input Output (ICIO) framework to account for inter-relationships between countries and economic sectors built on intermediate demand by industries and final demand by consumers and governments. This framework accounts for interlinkages between 2340 sectors across 65 countries allowing for a precise assessment of all emissions generated in the whole value chain of goods relative to the final demand. Data on carbon emissions from fossil fuels are provided by the IEA's $\mathrm{CO}_{2}$ emissions from fuel combustion database (International Energy Agency, 2018). All variables of the final system were converted into 2010 constant USD to account for crosscountry differences in inflation and movements in exchange rates.

This indicator bears two limitations. First, it does not include carbon emissions related to international freight. While data on carbon emissions from air and maritime transports exist, no methodology has been developed to allocate freight emissions to where transported products are consumed. ${ }^{31}$ Second, this indicator does not include other types of greenhouse gas emissions, in particular those related to agriculture such as methane and nitrous oxide, and carbon emissions linked to land use change (e.g. deforestation). Developing methodologies to include these emissions would significantly improve the coverage of this indicator. ${ }^{32}$

31 For instance, the emissions of a ship that delivers a cargo in Europe should be proportionally assigned to the various countries where goods are eventually consumed, which are difficult to identify.

32 Note that air emissions accounts based on the System of Environment-Economic Accounting (SEEA) Central Framework are available on OECD.Stat. They provide information on GHG emissions at the industry level - and therefore include methane, nitrous oxide, and other non-CO2 GHG emissions. For the sake of consistency across countries, only the information on $\mathrm{CO} 2$ emissions from fuel combustion in these SEEA accounts feeds into the computation of demand-based CO2 emissions. This information is supplemented with IEA estimates of $\mathrm{CO} 2$ emissions from fuel combustion in countries for which SEEA air emission accounts are not yet available. 


\section{Carbon emissions embodied in trade under the Equal Carbon Intensity (ECI) assumption}

\section{Definition}

The indicator reports the hypothetical amount of carbon emissions from fossil fuel combustion embodied in imports if imported goods were produced with a carbon intensity (i.e. emissions factors) equal to that of the importing country at a given time - the Equal Carbon Intensity (ECI) assumption. This indicator covers 65 countries and 34 industries between 1995 and 2011. The variables included in the indicator's dataset are the following:

- Country name.

- ISO code of the country.

- Industry code in the 2016 OECD Inter-Country Input Output (ICIO) framework. Definitions and equivalences with the International Standard Industrial Classification of All Economic Activities Revision 3 (ISIC Rev. 3) can be found in Appendix B.

- Year the data on carbon emissions was recorded.

- Imported emissions: The actual amount of carbon emissions from fossil fuel combustion, associated with the final consumption of a given industry in a given country, that are generated in other countries (scaled so that the 1995 value equals 100).

- ECI imported emissions: The hypothetical amount of carbon emissions from fossil fuel combustion, associated with the final consumption of a given industry in a given country, that would have been generated in other countries under the Equal Carbon Intensity (ECI) assumption (divided by the 1995 value of actual emissions).

\section{Sources, concepts, interpretation and limitations}

This indicator provides the hypothetical amount of carbon emissions from fossil fuel combustion that would have been generated if all countries participating in the value chain of imported goods associated with the final demand had a carbon intensity (i.e. emissions factors) for producing those goods equal to the importing country. In other words, these estimations provide the hypothetical carbon footprint of imports assuming an Equal Carbon Intensity (ECI) set by the importing country along the value chain.

Comparisons between ECI and actual imported emissions help to clarify the extent to which domestic production in a given country is substituted by a more or less carbon-intensive production technology in another country. This indicator can therefore shed light on the socalled pollution haven effect, which assumes that (some) domestic activities are relocated in jurisdictions with more lax environmental regulations and more carbon-intensive technology, consequently increasing the amount of global emissions.

This indicator is constructed using the OECD Inter-Country Input Output (ICIO) framework to account for inter-relationships between countries and economic sectors built on intermediate demand by industries and final demand by consumers and governments. ECI imported emissions are calculated by replacing emissions factors of each imported goods' global production segments by their equivalent in the importing country. Data on carbon emissions from fossil fuels are provided by the IEA's $\mathrm{CO}_{2}$ emissions from fuel combustion database (International Energy Agency, 2018). All variables of the final system 
were converted into 2010 constant USD to account for cross-country differences in inflation and movements in exchange rates.

This indicator complements the first indicator on embodied carbon emissions in trade. Introduced in an econometric model, the latter can provide evidence on whether the replacement of domestic production in a given country is caused by cross-country differences in environmental policy stringency. A positive difference between ECI and actual imported emissions would suggest that such a replacement is made in more carbonintensive countries, which is the second condition of the existence a pollution haven effect.

This indicator includes one caveat. The effect of international trade on global emissions should ideally be estimated by measuring the difference between a situation where countries trade among one another and a situation where all countries are autarkic. However, ECI imported emissions plus consumption-based domestic emissions represent only an imperfect proxy for the amount of emissions generated in a world under autarky. ${ }^{33}$ This is because ECI imported emissions are estimated using actual domestic consumption and production patterns, which would most likely be different under autarky.

\section{Scale, composition and technique effects of imported carbon emissions}

\section{Definition}

The indicator reports the hypothetical amount of carbon emissions from fossil fuel combustion embodied in imports under two scenarios:

- A scenario where the sectorial composition of the imports and their associated emissions factors remain constant over time, allowing only for the scale of the imports to vary;

- A scenario where only the emissions factors remain constant over time, allowing for both the scale and the composition of the imports to vary.

The baseline year is set to 1995. This indicator covers 65 countries and 34 industries between 1995 and 2011. The variables included in the indicator's dataset are the following:

- Country name

- ISO code of the country

- Year the data on carbon emissions was recorded

- Imported emissions: The actual amount of carbon emissions from fossil fuel combustion, associated with the final consumption of a given country, that are generated in other countries (scaled so that the 1995 value equals 100)

- Imported emissions by scale effect: The hypothetical amount of carbon emissions from fossil fuel combustion, associated with the final consumption of a given country, that would have been generated in other countries if both the composition of industries making the final consumption and emissions factors would have remained constant over time (scaled so that the 1995 value equals 100)

33 Consumption-based domestic emissions are production-based domestic emissions minus exported emissions. Adding ECI imported emissions would provide the amount of emissions generated in a country under autarky, holding consumption and production patterns constant. 
- Imported emissions by scale and composition effects: The hypothetical amount of carbon emissions from fossil fuel combustion, associated with the final consumption of a given country, that would have been generated in other countries if emissions factors had remained constant over time (scaled so that the 1995 value equals 100).

\section{Sources, concepts, interpretation and limitations}

Conceptually, growth in carbon emissions over time can be driven by three effects: scale, composition and technique. The scale effect is merely the component of the growth explained by the change in the overall volume of imported goods (because of economic growth, for instance), holding their composition and carbon intensities constant. The composition effect accounts for the change in the mix of imported goods resulting in a more or less carbon-intensive basket of traded goods, holding emissions factors constant. The technique effect captures the changes in emissions factors, holding scale and composition fixed. Thus, for example, an observed decline in imported $\mathrm{CO}_{2}$ emissions could be due to a mere decrease in the volume of imports (scale effect), the imports of the same goods being produced in a cleaner way (technique effect), or an increase in imports of cleaner goods relative to the more carbon-intensive goods (composition effect).

The series provided in this indicator allows estimating how much of the growth in the imported emissions of a country comes from: (i) changes in the volume of imports; (ii) changes in the imports composition and; (iii) changes in the carbon intensity in countries where emissions have been generated.

Following Levinson (2009), it is possible to create two hypothetical series of imported emissions. The first one is a series that represents how emissions would have changed over time if the composition of imports and emissions factors had remained constant. This series would capture the scale effect only since it is its only source of variation. The second series represents how emissions would have changed over time if only the technology had remained constant, consequently allowing the scale and the composition of imports to vary and therefore capturing these two effects.

Quite simply then, the composition and the technique effects can be estimated at any point in time. The composition effect is calculated as the difference between the series capturing the scale and the composition effect and the series capturing the scale effect only. The difference between the series capturing the scale, the composition effect, and the actual imported emissions - which are moved by moved by the scale, composition and the technique effects - consequently estimates the technique effect. For the sake of clarity, a fictitious example is provided below.

Similar to the other indicators on carbon emissions embodied in trade, this indicator is constructed using the OECD Inter-Country Input Output (ICIO) framework to account for inter-relationships between countries and economic sectors. "Imported emissions by scale and composition effects" are calculated by replacing emissions factors of each imported goods' global production segments by their equivalent in the baseline year (i.e. the year 1995) to maintain technology constant. "Imported emissions by scale effect" are calculated by multiplying the emissions from the basket of imports in the baseline year by the average growth rate of imports.

Data on carbon emissions from fossil fuels are provided by the IEA's $\mathrm{CO}_{2}$ emissions from fuel combustion database (International Energy Agency, 2018). All variables of the final 
system were converted into 2010 constant USD to account for cross-country differences in inflation and movements in exchange rates.

From a pollution-haven perspective, capturing the magnitude of the composition effect seems particularly relevant. Working with the amount of imported $\mathrm{CO}_{2}$ emissions only could be misleading. The pollution-haven effect predicts that some countries specialise in goods from relatively more pollution-intensive industries, a pattern of specialisation that may be observed through the evolution of the composition of exports and imports. If the composition of imports does not change over time, it would seem inaccurate to conclude that some trade specialisation is occurring.

Table A.1. Fictitious time series for OECD countries

\begin{tabular}{|c|c|c|c|c|}
\hline ISO code & Year & Imported emissions & $\begin{array}{c}\text { Imported emissions } \\
\text { by scale effect }\end{array}$ & $\begin{array}{l}\text { Imported emissions by scale } \\
\text { and composition effects }\end{array}$ \\
\hline OECD & 1995 & 100 & 100 & 100 \\
\hline OECD & 1996 & 98 & 94 & 104 \\
\hline OECD & 1997 & 91 & 93 & 109 \\
\hline OECD & 1998 & 103 & 103 & 117 \\
\hline OECD & 1999 & 105 & 101 & 120 \\
\hline OECD & 2000 & 111 & 98 & 149 \\
\hline OECD & 2001 & 103 & 103 & 142 \\
\hline OECD & 2002 & 101 & 94 & 134 \\
\hline OECD & 2003 & 105 & 101 & 131 \\
\hline OECD & 2004 & 116 & 106 & 152 \\
\hline OECD & 2005 & 124 & 107 & 181 \\
\hline OECD & 2006 & 138 & 112 & 219 \\
\hline OECD & 2007 & 132 & 117 & 225 \\
\hline OECD & 2008 & 158 & 130 & 279 \\
\hline OECD & 2009 & 124 & 111 & 214 \\
\hline OECD & 2010 & 137 & 109 & 260 \\
\hline OECD & 2011 & 144 & 114 & 280 \\
\hline OECD & 2012 & 147 & 116 & 286 \\
\hline OECD & 2013 & 150 & 119 & 292 \\
\hline OECD & 2014 & 153 & 121 & 298 \\
\hline OECD & 2015 & 156 & 123 & 303 \\
\hline
\end{tabular}

Source: Authors' elaboration. 
It is possible to infer the growth rate of each series over the period 1995-2015:

- Actual imported emissions have increased by $56 \%$, the growth rate of the "imported emissions" series.

- Holding their composition and carbon intensities constant, imported emissions would have increased by $23 \%$, the growth rate of the "imported emissions by scale effect" series.

- Holding only their carbon intensities constant, imported emissions would have increased by $203 \%$, the growth rate of the "imported emissions by scale and composition effects" series.

This actual increase of $56 \%$ can be decomposed into the scale, composition and technique effects:

- The scale effect accounts for the growth of the "imported emissions by scale effect" series, that is, 23 percentage points.

- The composition effect is calculated as the difference in the growth rates of the "imported emissions by scale and composition effects" series and the "imported emissions by scale effect" series, that is, 180 percentage points.

- The technique effect is calculated as the difference in the growth rates of the actual "imported emissions" series ${ }^{34}$ and the "imported emissions by scale and composition effects" series, that is, -147 percentage points.

The following figure summarises this decomposition.

Figure A.1. Decomposing the increase of imported emission into scale, composition and technique effects

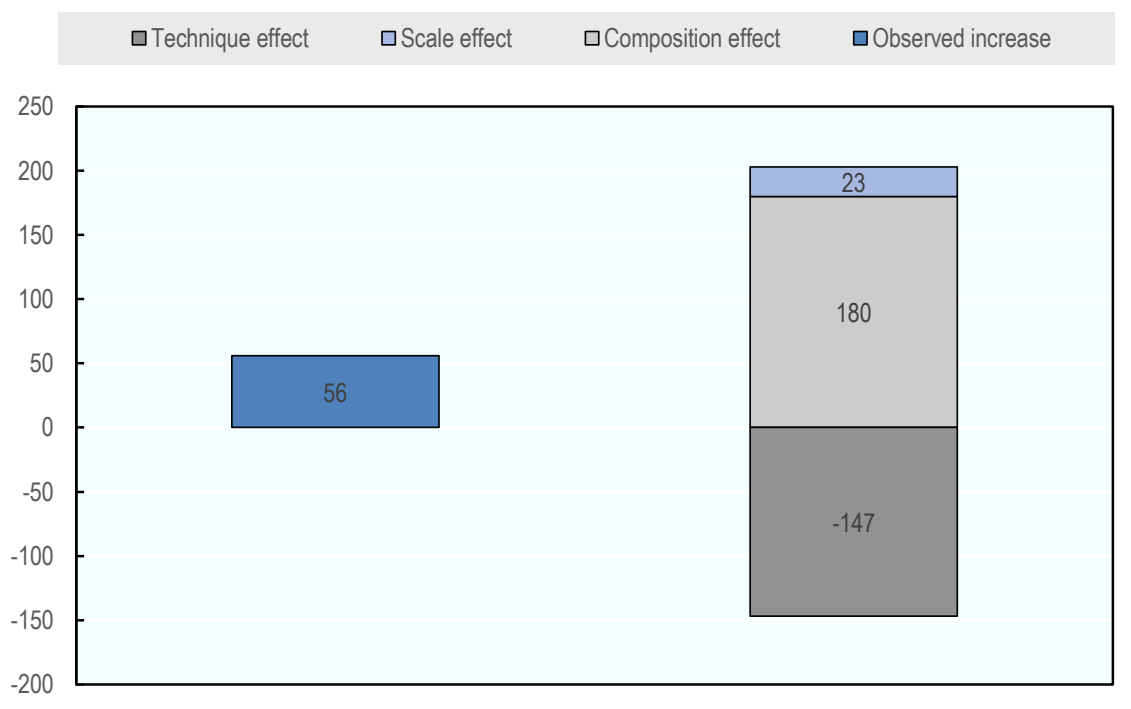

Source: Authors' elaboration.

34 The actual "imported emissions" series is moved by the scale, composition and the technique effects. 
Table A.2. Table of equivalences between 2016 ICIO codes and ISIC Rev.3 categories

\begin{tabular}{|c|c|c|c|}
\hline $\mathrm{ICIO}$ code & ISIC3 categories & Definition & Abbreviation \\
\hline C01T05 & $01,02,03,04,05$ & Agriculture, hunting, forestry and fishing & AGR \\
\hline C10T14 & $10,11,12,13,14$ & Mining and quarrying & MIN \\
\hline C15T16 & 15,16 & Food products, beverages and tobacco & FOD \\
\hline C17T19 & $17,18,19$ & Textiles, textile products, leather and footwear & TEX \\
\hline $\mathrm{C} 20$ & 20 & Wood and products of wood and cork & WOD \\
\hline $\mathrm{C} 21 \mathrm{~T} 22$ & 21,22 & Pulp, paper, paper products, printing and publishing & PAP \\
\hline $\mathrm{C} 23$ & 23 & Coke, refined petroleum products and nuclear fuel & PET \\
\hline $\mathrm{C} 24$ & 24 & Chemicals & $\mathrm{CHM}$ \\
\hline $\mathrm{C} 25$ & 25 & Rubber \& plastics products & RBP \\
\hline $\mathrm{C} 26$ & 26 & Other non-metallic mineral products & NMM \\
\hline $\mathrm{C} 27$ & 27 & Basic metals & MET \\
\hline $\mathrm{C} 28$ & 28 & Fabricated metal products, except machinery \& equipment & FBM \\
\hline $\mathrm{C} 29$ & 29 & Machinery \& equipment, nec & MEQ \\
\hline С30T33X & $30,32,33$ & Computer, electronic and optical equipment & CEQ \\
\hline C31 & 31 & Electrical machinery \& apparatus, nec & ELQ \\
\hline C34 & 34 & Motor vehicles, trailers \& semi-trailers & MTR \\
\hline $\mathrm{C} 35$ & 35 & Other transport equipment & TRQ \\
\hline С36Т37 & 36,37 & Manufacturing nec; recycling (include Furniture) & OTM \\
\hline C40T41 & 40,41 & Electricity, gas and water supply & EGW \\
\hline $\mathrm{C} 45$ & 45 & Construction & CON \\
\hline C50T52 & $50,51,52$ & Wholesale \& retail trade; repairs & WRT \\
\hline C55 & 55 & Hotels \& restaurants & HTR \\
\hline С60T63 & $60,61,62,63$ & Transport and storage & TRN \\
\hline C64 & 64 & Post \& telecommunications & PTL \\
\hline С65T67 & $65,66,67$ & Financial intermediation & FIN \\
\hline $\mathrm{C} 70$ & 70 & Real estate activities & REA \\
\hline C71 & 71 & Renting of machinery \& equipment & $\mathrm{RMQ}$ \\
\hline $\mathrm{C} 72$ & 72 & Computer \& related activities & ITS \\
\hline С73Т74 & 73,74 & Other Business Activities & $\mathrm{OBZ}$ \\
\hline $\mathrm{C} 75$ & 75 & Public admin. \& defence; compulsory social security & GOV \\
\hline $\mathrm{C} 80$ & 80 & Education & EDU \\
\hline $\mathrm{C} 85$ & 85 & Health \& social work & $\mathrm{HTH}$ \\
\hline С90Т93 & $90,91,92,93$ & Other community, social \& personal services & OTS \\
\hline C95 & 95 & Private households with employed persons & $\mathrm{PVH}$ \\
\hline
\end{tabular}

Note: ICIO industries can encompass more than one ISIC Rev. 3 categories. NEC stands for non-elsewhere categorized.

Source: The 2016 OECD ICIO framework. 
Table A.3. Countries and economies covered by the indicators on carbon emissions embodied in trade

\begin{tabular}{|c|c|}
\hline Argentina & Latvia \\
\hline Australia & Lithuania \\
\hline Austria & Luxembourg \\
\hline Belgium & Malaysia \\
\hline Brazil & Malta \\
\hline Brunei Darussalam & Mexico \\
\hline Bulgaria & Morocco \\
\hline Cambodia & Netherlands \\
\hline Canada & New Zealand \\
\hline Chile & Norway \\
\hline China, People's Republic of & Peru \\
\hline Colombia & Philippines \\
\hline Costa Rica & Poland \\
\hline Croatia & Portugal \\
\hline Cyprus 1,2 & Korea \\
\hline Czech Republic & Romania \\
\hline Denmark & Russian Federation \\
\hline Estonia & Saudi Arabia \\
\hline Finland & Singapore \\
\hline France & Slovakia \\
\hline Germany & Slovenia \\
\hline Greece & South Africa \\
\hline Hong Kong, China & Spain \\
\hline Hungary & Sweden \\
\hline Iceland & Switzerland \\
\hline India & Taiwan \\
\hline Indonesia & Thailand \\
\hline Ireland & Tunisia \\
\hline Israel & Turkey \\
\hline Italy & United Kingdom \\
\hline Japan & United States \\
\hline Korea & Viet Nam \\
\hline
\end{tabular}

1. Note by Turkey: The information in this document with reference to "Cyprus" relates to the southern part of the Island. There is no single authority representing both Turkish and Greek Cypriot people on the Island. Turkey recognises the Turkish Republic of Northern Cyprus (TRNC). Until a lasting and equitable solution is found within the context of the United Nations, Turkey shall preserve its position concerning the "Cyprus" issue.

2. Note by all the European Union Member States of the OECD and the European Union: The Republic of Cyprus is recognised by all members of the United Nations with the exception of Turkey. The information in this document relates to the area under the effective control of the Government of the Republic of Cyprus. 


\section{A2. Embodied raw materials in trade}

\section{Definition}

This indicator originates from the database provided by UNEP International Resource Panel (2016) ${ }^{35}$ It estimates the total raw materials embedded in the final consumption for all countries between 1990 and 2010. Estimates of this consumption-based material extraction are called material footprint (MF) or raw material consumption (RMC). The different categories of raw materials considered are biomass, fossil fuels, metal ores, and non-metallic minerals. The variables included in the indicator's dataset are the following.

- Country name.

- ISO code of the country.

- Year the data on material footprint were recorded.

- Category of raw material (biomass, fossil fuels, metal ores, and non-metallic minerals).

- Material footprint variables: ${ }^{36}$

- Material footprint $(M F)$ : Total material extraction associated with the final demand of the country considered (in tonnes).

- Material footprint of exports (MFE): Total material extraction in the country considered associated with the final demand from other countries (in tonnes).

- Material footprint of imports (MFI): Total material extraction in other countries associated with the final demand in the country considered (in tonnes).

\section{Sources, concepts, interpretation and limitations}

This indicator provides the total amount of raw materials embedded in the final consumption of a given country, the so-called material footprint. Such estimates decompose the global value chain of a country's final demand and assign the amount of raw materials extracted to each production segment. In other words, this indicator traces the entire value chain of traded products for final consumption to the original sources of extraction and calculates the upstream amount of raw materials that were embedded domestically, both in imports and exports originating from outside the local economy. Embedded raw materials in imports and exports, also provided by the indicator, can therefore be used to measure embedded raw materials in trade.

This indicator comes from the database provided by UNEP International Resource Panel (2016), which uses a global multi-regional input-output (MRIO) ${ }^{37}$ model to account for inter-relationships between countries and economic sectors built on intermediate demand by industries and final demand by consumers and governments. This framework accounts for interlinkages between 14787 sectors and across 186 countries, allowing for a precise

35 The complete original dataset can be downloaded at http://environmentlive.unep.org/material

36 Conceptually, we have MF = MFI - MFE + domestic extraction.

37 The global MRIO framework used in UNEP International Resource Panel (2016) is Eora, which developed by the University of Sydney (see Lenzen et al., 2013). 
assessment of all raw materials used in the whole value chain of goods relative to the final demand. Details on the methodology used to construct such a framework in the context of raw materials can be found in Wiebmann et al. (2015).

This indicator has three limitations. First, raw materials categories considered by the indicator are heterogeneous and may have different environmental impacts. For instance, the biomass category includes renewable materials (e.g. food) while all minerals are classified as non-renewable. Comparisons across categories can therefore be ambiguous.

The second issue is that raw materials embedded in traded goods are measured in mass weight, which can complicate the interpretation from an environmental perspective. For example, an observed decrease in the imports of fossil fuels might be due to either a decrease in consumption or a switch to a more energy-dense fuel. But this does not necessarily translate into an environmental improvement. In 2018, no method to address these issues was available, and breaking down the indicator by categories of raw materials remains the most sensible approach to exploiting the data.

Finally, the results provided by this indicator are sensitive to the methodology used. Results for demand-based indicators of material flows vary significantly with the type of global MRIO frameworks used for estimations because of their structural differences (OECD, $2017_{[4]}$ ). The OECD recommends working towards a harmonised global MRIO database which could update and improve this indicator.

\section{A3. The volume of trade in environmentally-related goods}

\section{Definition}

This indicator reports the amount of exports and imports of environmentally-related goods as defined in the Combined List of Environmental Goods (CLEG) in current USD for all countries between 2003 and 2016. The variables included in the dataset are:

- Country name.

- ISO code of the country.

- Year the data on trade flows was recorded.

- HS code: The code in the Harmonized System (HS) identifying the traded good. Codes for years 2002-2008 are reported in the $\mathrm{H} 2$ version of the HS, codes for years 2009-2011 are reported in the H3 version of the HS, codes for years 20122016 are reported in the H4 version of the HS.

- Medium: Environmental medium of the good. The environmental media covered by this indicator are: $\mathrm{APC}=$ Air pollution control; $\mathrm{CRE}=$ Cleaner or more resource efficient technologies and products; EPP = Environmentally preferable products based on end use or disposal characteristics; HEM = Heat and energy management; MON = Environmental monitoring, analysis and assessment equipment; NRP = Natural resources protection; NVA $=$ Noise and vibration abatement; REP $=$ Renewable energy plant; SWM = Management of solid and hazardous waste and recycling systems; SWR = Clean up or remediation of soil and water; WAT = Waste water management and potable water treatment.

- Exports value: Value of exports from the considered country in current USD.

- Exports weight: Weight of exports from the considered country in kilograms. 
- Imports value: Value of imports in the considered country in current USD.

- Imports weight of imports in the considered country in kilograms.

\section{Concepts, interpretation and limitations}

Constructing an indicator that measures the volume of trade in environmental goods faces two fundamental challenges.

First, there is no consensus on which traded goods should be considered "environmental". A first attempt to outline the concept of environmental goods was made by a combined OECD and Eurostat working group in the late 1990s: "The environmental goods and services industry consists of activities which produce goods and services to measure, prevent, limit, minimise or correct environmental damage to water, air and soil, as well as problems related to waste, noise and eco-systems. This includes cleaner technologies, products and services that reduce environmental risk and minimise pollution and resource use" (OECD-Eurostat, 1999 $\left.{ }_{[5]}\right)$. This definition is very broad and, potentially, a very large number of products could correspond to it.

Second, even if there was an international consensus on the goods that should be considered environmental, deriving an associated list of codes from the Harmonized System (HS) remains particularly challenging for several reasons: i) the presence of classifications in the HS that include both environmental and non-environmental products; ii) the large number of goods and products with multiple uses, including non-environmental uses, and; iii) the presence of both intermediate and finished products whose classification often differs by industry, with some finished products having their own distinct code and others not (Steenblik, 2005 $[6]$ ).

Considering these difficulties, this indicator takes a pragmatic approach and is based on what seems to be, as of today, the most practical list of environmentally-related goods: the Combined List of Environmental Goods (CLEG). The CLEG provides the Harmonized System 6-digit level codes of 248 products. It is based on a combination of three lists: i) the OECD's indicative list of climate-change-relevant goods (more than 150 are listed) for a plurilateral environmental goods and services (PEGS) agreement (OECD, 2010 $\left.0_{[7]}\right)$; ii) the list of 154 products proposed by the "Friends group" 38 , which was a subset of the more than 400 products submitted by WTO members for the trade and environment part of the Doha negotiations (WTO, 2009 ${ }_{[8]}$ ); and iii) the list of 54 products on which the Asia-Pacific Economic Cooperation (APEC) countries have negotiated tariff reductions. ${ }^{39}$ In addition, this list provides a breakdown for ten non-exclusive categories of goods that relate to different environmental medium.

The main limitations of the CLEG are the aforementioned issues - covering HS lines that include both environmental and non-environmental goods and, products characterized by multiple end-uses, including non-environmental applications. However, its comprehensiveness also reflects the approach of trade negotiators - at the WTO and APEC - who have considered these tariff lines to be part of a trade agreement on environmental

38 The Friends Group is composed of Canada, the European Union, Japan, Korea, New Zealand, Norway, Switzerland, Chinese Taipei, and the United States.

39 For a complete description of the APEC list, see: https://www.apec.org/Meeting-Papers/LeadersDeclarations/2012/2012_aelm/2012_aelm_annexC.aspx. 
goods. In addition, this list was used in numerous works at the OECD that address trade in environmentally-related goods, including (Sauvage, $\left.2014_{[9]}\right)$.

\section{Sources, measurability and data quality}

The source data to calculate the volume of trade of environmentally-related goods is the Base pour l'analyse du commerce international (BACI), or BACI International Trade database. ${ }^{40}$ Data on traded volumes are available from the UN COMTRADE database, the repository of official international trade statistics. However, this database is contaminated by missing values (i.e. values not reported by countries) and by discrepancies (i.e. when the exporter and importer report two different numbers for the same trade flow).

The BACI database provides a single consistent figure for each bilateral flow that corrects these discrepancies in mirror flows. The reconciliation methodology relies on two steps. ${ }^{41}$ First, removing transport costs from reported imports since the latter are generally reported cost, insurance and freight (CIF) as opposed to export values, which are reported free on board (FOB). Second, evaluating the accuracy of each country's reports and using it as a weight to average reported mirror flows, now cleaned of CIF rates. ${ }^{42}$

For these reasons, the BACI database is more reliable than the raw data observed in the COMTRADE database and is therefore used to construct this indicator. Therefore, it should also be noted that numbers from this indicator can significantly differ from official data from national customs agencies, which are the main sources of COMTRADE database.

\section{Issues with the updates of the Harmonized System (HS)}

The Harmonized System is updated every five years. Each update may modify, merge, or divide existing HS codes or create new ones. The UN COMTRADE website provides details on the relationships between different HS codes. These relationships take four different forms:

- 1:1: The code in an updated HS version remains the same as in the previous HS version.

- 1:numerous: The code in an updated HS version is a merge of several codes from the previous HS version.

- numerous:1: Several codes in an updated HS version are created from one code from the previous HS version.

- numerous:numerous: Several codes in an updated HS version are created from both a split and a merge of several codes from the previous version.

40 Data from BACI International Trade database can be downloaded at http://www.cepii.fr/CEPII/en/bdd modele/presentation.asp?id=1.

41 For a complete explanation of the methodology, see Gaulier and Zignago.

42 Concretely, the reconciled value $(R V)$ of exporter $V_{i}$ and importer $V_{j}$ is defined as $R V=\omega * V_{i}+$ $(1-\omega) * V_{j}$, where $\omega$ is a measure of the relative quality of the reports of country $i$ compared to the reports of country $j$. 
From such relationships, also called correlations, each code can be linked to all related codes in another HS version, previous or subsequent. ${ }^{43}$ The following figure provides illustrative examples of these relationships.

Figure A.2. Relationships between classification codes in different HS versions

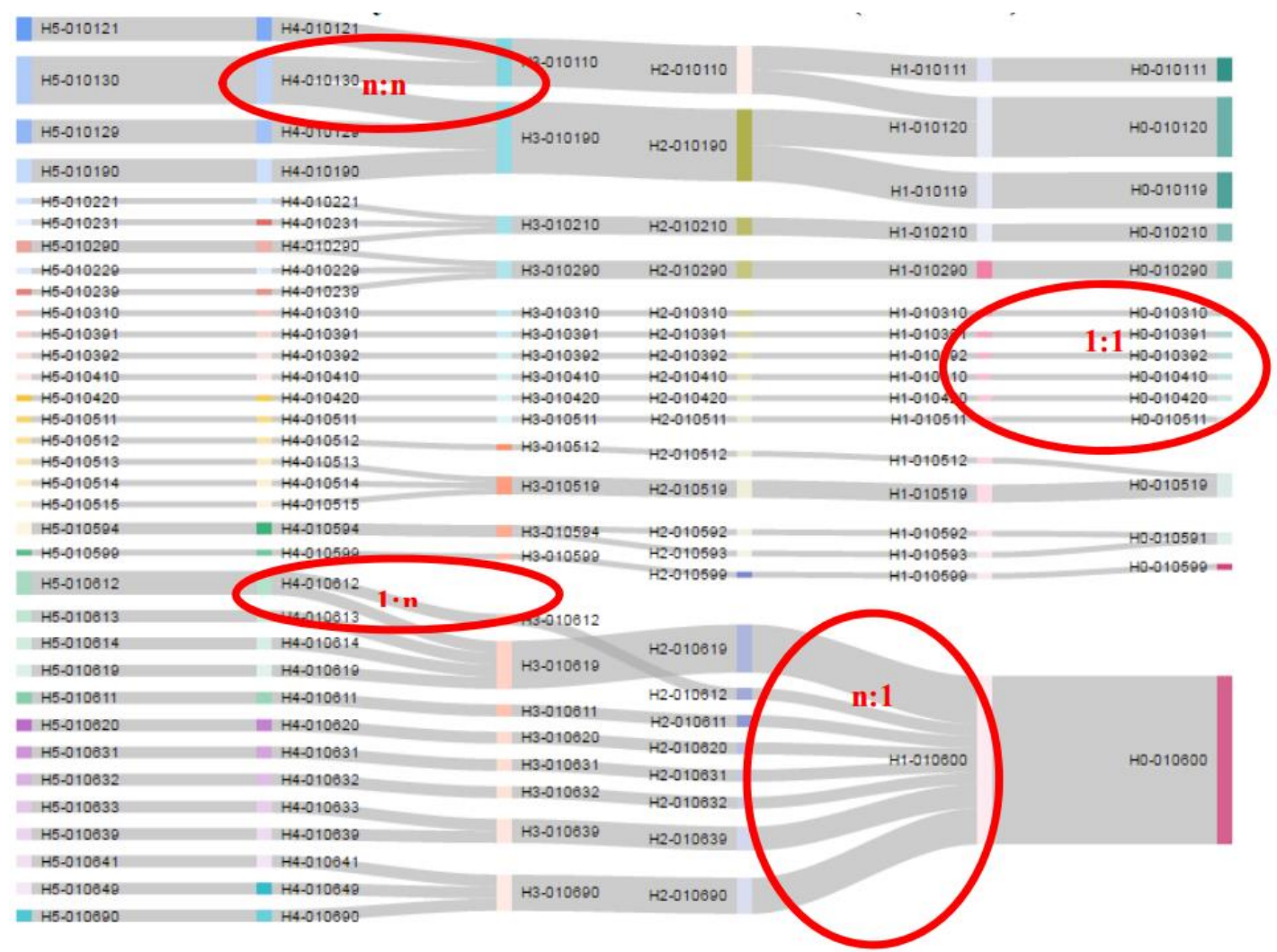

Source: UN COMTRADE, https://unstats.un.org/unsd/trade/classifications/correspondence-tables.asp

\section{Finding a correspondent code in $\mathrm{HS}$ versions}

The CLEG was defined in the HS version of 2007. To create a time series covering the 2002-2017 period over these categories of goods, it is necessary for each code in the lis., to find a correspondent code in the HS versions of 2002, 2012 and $2017 .{ }^{44}$

To establish such correspondences, the UN Statistics Division (UNSD) approach is to convert a code of a given version into only one code of another HS version. ${ }^{45}$ This code is selected amongst those that correlate (i.e. those identified through the relationships defined

43 Correlation tables can be found at: https://unstats.un.org/unsd/trade/classifications/correspondencetables.asp

44 While correspondences between HS versions of 2007 and 2017 exist, trade data is not yet available. The next version of the indicator will provide figures for the year 2017 using the correspondences defined in this section.

45 An alternative is to divide the trade value of a code into its correlates according to their trade share. However, this approach implies huge assumptions if the correlated code is in tied to other codes in the current HS version. 
above). Therefore, it is important to note that correspondences provide the closest classification code in another HS version, but not (necessarily) an identical one. As a result, observed variations in the volume of trade in years of an HS update for some categories of goods can be partly due to changes in their definition in the Harmonized System.

UN COMTRADE provides correspondence tables for a given HS version to earlier ones. Therefore, these tables can be directly used to define the correspondences from the 2007 HS version - the CLEG baseline year - to the 2002 HS version. The methodology used to construct these tables can then be replicated to establish correspondences between the 2007 HS version and subsequent HS versions (2012 and 2017 versions).

This methodology works as follows.

From the 2007 HS version to subsequent HS versions, all codes with a 1:1 or a 1:n relationship have a straightforward correspondence since there is only one available code.

For all n:1 and n:n relationships - which involve many correlated codes in a subsequent HS version - the selection is made using the "retained code" rule. The retained code rule assigns the HS 2007 code to the code itself if one of the correlated codes is identical. The retained code rule is based on the general World Custom Organization (WCO) praxis that maintains the existing code only if there has been no substantial change of scope (United Nations Statistics Division, 2017).

Otherwise, if no correlated code is identical, it is manually decided which HS codes are to correspond with the original code in the CLEG. HS codes (in the 2012 and 2017 HS versions) are analysed to determine whether they can still be considered as "environmental". This is done by looking at the name and description of the new codes in the COMTRADE database.

To sum up, changes made to the list for correspondences in subsequent HS versions are as follows:

- From HS 2007 to HS 2012. All HS 2007 codes with n:1 and n:n relationships have an identical code in the HS 2012 version. Therefore, the "retained code" rule is applied to establish the correspondent of these codes.

- From HS 2007 to HS 2017. All HS 2007 codes with n:1 and n:n relationships have an identical code in the HS 2017 version except code 441872, which separates into 441873 and 441875 . HS 2017 code 441873 refers to "Assembled flooring panels of bamboo" while 441875 refers to "Others". Flooring panels of bamboo are considered an environmentally preferable product and therefore code 441873 is retained. Two notable exceptions are made to the "retained code" assignment rule. HS 2007 codes 870290 and 870390 are split in other codes including identical ones. However, these codes also correlate with 870240 and 870380 , which respectively refers to "Motor vehicles for the transport of ten or more persons with only electric motor for propulsion" and "Other vehicles, with only electric motor for propulsion". Again, these goods can be considered environmentally preferable products and, therefore, these categories are retained instead of the assigned definition provided by the identical code rule.

Table A.5 provides correspondences for the original HS codes of CLEG in all other HS versions. 
Table A.4. Description of HS codes covered by the indicator on the volume of trade in environmentally related goods

\begin{tabular}{|c|c|c|c|}
\hline $\begin{array}{l}\text { HS } \\
\text { code }\end{array}$ & Classification & Description & Medium \\
\hline 380210 & $\mathrm{H} 3$ & Carbon; activated & WAT \\
\hline 390940 & H3 & Phenolic resins; in primary forms & HEM \\
\hline 392010 & H3 & $\begin{array}{l}\text { Plastics; plates, sheets, film, foil and strip (not self-adhesive), of polymers of } \\
\text { ethylene, non-cellular and not reinforced, laminated, supported or similarly combined } \\
\text { with other materials }\end{array}$ & SWM \\
\hline 392030 & H3 & $\begin{array}{l}\text { Plastics; of polymers of styrene, plates, sheets, film, foil and strip (not self-adhesive), } \\
\text { non-cellular and not reinforced, laminated, supported or similarly combined with } \\
\text { other materials }\end{array}$ & HEM \\
\hline 392111 & H3 & Plastics; plates, sheets, film, foil and strip, of polymers of styrene, cellular & HEM \\
\hline 392113 & H3 & Plastics; plates, sheets, film, foil and strip, of polyurethanes, cellular & HEM \\
\hline 392510 & H3 & $\begin{array}{l}\text { Plastics; builders' ware, reservoirs, tanks, vats and similar containers of a capacity } \\
\text { exceeding } 300 \text { litres }\end{array}$ & REP \\
\hline 400259 & $\mathrm{H} 3$ & $\begin{array}{l}\text { Rubber; synthetic, acrylonitrile-butadiene rubber (NBR), (other than latex), in primary } \\
\text { forms or in plates, sheets or strip }\end{array}$ & SWM \\
\hline 441872 & H3 & Wood; assembled flooring panels, multilayer, other than mosaic & EPP \\
\hline 450410 & H3 & $\begin{array}{l}\text { Cork; blocks, plates, sheets and strip, tiles of any shape, solid cylinders (including } \\
\text { discs), of agglomerated cork (with or without a binding substance) }\end{array}$ & HEM \\
\hline 450490 & $\mathrm{H} 3$ & $\begin{array}{l}\text { Cork; articles of agglomerated cork (with or without a binding substance), n.e.c. in } \\
\text { heading no. } 4504\end{array}$ & HEM \\
\hline 530310 & H3 & $\begin{array}{l}\text { Jute and other textile bast fibres; raw or retted, but not spun, (excluding flax, hemp } \\
\text { (cannabis sativa L.), and ramie) }\end{array}$ & EPP \\
\hline 530500 & $\mathrm{H} 3$ & $\begin{array}{l}\text { Coconut, abaca (Manila hemp or Musa textilis Nee), ramie and other vegetable } \\
\text { textile fibres n.e.c., raw or processed but not spun; tow, noils and waste of these } \\
\text { fibres (including yarn waste and garnetted stock) }\end{array}$ & EPP \\
\hline 540500 & H3 & $\begin{array}{l}\text { Monofilament, synthetic; of } 67 \text { decitex or more and of which no cross-sectional } \\
\text { dimension exceeds } 1 \mathrm{~mm} \text {, strip and the like (e.g. artificial straw), of synthetic textile } \\
\text { materials with width not over } 5 \mathrm{~mm}\end{array}$ & HEM \\
\hline 560314 & H3 & $\begin{array}{l}\text { Nonwovens; whether or not impregnated, coated, covered or laminated, of man- } \\
\text { made filaments, (weighing more than } 150 \mathrm{~g} / \mathrm{m} 2 \text { ) }\end{array}$ & WAT \\
\hline 560721 & H3 & Twine; binder or baler twine, of sisal or other textile fibres of the genus agave & EPP \\
\hline 560790 & H3 & $\begin{array}{l}\text { Twine, cordage, ropes, cables; of materials n.e.c. in heading no. } 5607 \text {, whether or } \\
\text { not plaited, braided or impregnated, coated, covered, or sheathed with rubber or } \\
\text { plastics }\end{array}$ & EPP \\
\hline 560811 & $\mathrm{H} 3$ & Twine, cordage or rope; fishing nets, made up, of man made textile materials & NRP \\
\hline 560890 & H3 & Twine, cordage or rope; knotted netting, of other than man-made textiles & NRP \\
\hline 630510 & H3 & $\begin{array}{l}\text { Sacks and bags; of a kind used for the packing of goods, of jute or of other textile } \\
\text { bast fibres of heading no. } 5303\end{array}$ & EPP \\
\hline 680610 & H3 & $\begin{array}{l}\text { Slag wool, rock wool and similar mineral wools (including intermixtures thereof), in } \\
\text { bulk, sheets or rolls }\end{array}$ & HEM \\
\hline 680690 & H3 & $\begin{array}{l}\text { Minerals; mixtures and articles of heat-insulating, sound-insulating or sound- } \\
\text { absorbing mineral materials, other than those of heading no. } 6811 \text { or } 6812 \text { or of } \\
\text { chapter } 69\end{array}$ & HEM \\
\hline 680800 & H3 & $\begin{array}{l}\text { Panels, boards, tiles, blocks and the like; of vegetable fibre, of straw, shavings, chips, } \\
\text { particles, sawdust or other waste, of wood, agglomerated with cement, plaster or } \\
\text { other mineral binders }\end{array}$ & HEM \\
\hline 681011 & $\mathrm{H} 3$ & $\begin{array}{l}\text { Cement, concrete or artificial stone; building blocks or bricks, whether or not } \\
\text { reinforced }\end{array}$ & HEM \\
\hline 681019 & H3 & $\begin{array}{l}\text { Cement, concrete or artificial stone; tiles, flagstones and similar, (excluding building } \\
\text { blocks and bricks) whether or not reinforced }\end{array}$ & HEM \\
\hline 681091 & $\mathrm{H} 3$ & $\begin{array}{l}\text { Cement, concrete or artificial stone; prefabricated structural components for building } \\
\text { or civil engineering, whether or not reinforced }\end{array}$ & HEM \\
\hline 691010 & H3 & $\begin{array}{l}\text { Ceramic sinks, wash basins, wash basin pedestals, baths, bidets, water closet pans, } \\
\text { flushing cisterns, urinals and similar sanitary fixtures; of porcelain or china }\end{array}$ & WAT \\
\hline 700800 & $\mathrm{H} 3$ & Glass; multiple-walled insulating units of glass & HEM \\
\hline
\end{tabular}




\begin{tabular}{|c|c|c|c|}
\hline 700991 & $\mathrm{H} 3$ & Glass mirrors; unframed, excluding rear-view mirrors for vehicles & REP \\
\hline 700992 & $\mathrm{H} 3$ & Glass mirrors; framed, excluding rear-view mirrors for vehicles & REP \\
\hline 701931 & $\mathrm{H} 3$ & Glass fibres; non-woven products, mats & HEM \\
\hline 701939 & $\mathrm{H} 3$ & $\begin{array}{l}\text { Glass fibres; webs, mattresses, boards and similar non-woven products excluding } \\
\text { mats and thin sheets }\end{array}$ & HEM \\
\hline 730210 & $\mathrm{H} 3$ & Iron or steel, railway or tramway track construction material; rails & CRE \\
\hline 730230 & $\mathrm{H} 3$ & $\begin{array}{l}\text { Iron or steel, railway or tramway track construction material; switch blades, crossing } \\
\text { frogs, point rods and other crossing pieces }\end{array}$ & CRE \\
\hline 730240 & $\mathrm{H} 3$ & $\begin{array}{l}\text { Iron or steel, railway or tramway track construction material; fish-plates and sole } \\
\text { plates }\end{array}$ & CRE \\
\hline 730290 & $\mathrm{H} 3$ & $\begin{array}{l}\text { Iron or steel, railway or tramway track construction material; n.e.c. in heading no. } \\
7302\end{array}$ & CRE \\
\hline 730300 & $\mathrm{H} 3$ & Cast iron; tubes, pipes and hollow profiles & WAT \\
\hline 730431 & $\mathrm{H} 3$ & $\begin{array}{l}\text { Iron or non-alloy steel (excluding cast iron); seamless, cold-drawn or cold-rolled, } \\
\text { tubes, pipes and hollow profiles of circular cross-section }\end{array}$ & WAT \\
\hline 730490 & $\mathrm{H} 3$ & $\begin{array}{l}\text { Iron or steel (excluding cast iron); seamless, tubes, pipes and hollow profiles, } \\
\text { seamless, n.e.c. in heading no. } 7304\end{array}$ & WAT \\
\hline 730630 & $\mathrm{H} 3$ & $\begin{array}{l}\text { Iron or non-alloy steel (excluding cast iron); tubes and pipes (not seamless), welded, } \\
\text { of circular cross-section, n.e.c. in chapter } 73\end{array}$ & WAT \\
\hline 730690 & $\mathrm{H} 3$ & $\begin{array}{l}\text { Iron or steel (excluding cast iron); tubes, pipes and hollow profiles (not seamless), } \\
\text { n.e.c. in chapter } 73\end{array}$ & WAT \\
\hline 730820 & $\mathrm{H} 3$ & Iron or steel; structures and parts thereof, towers and lattice masts & REP \\
\hline 730890 & $\mathrm{H} 3$ & Iron or steel; structures and parts thereof, n.e.c. in heading no. 7308 & REP \\
\hline 730900 & $\mathrm{H} 3$ & $\begin{array}{l}\text { Reservoirs, tanks, vats and similar containers; for any material (excluding } \\
\text { compressed or liquefied gas), of iron or steel, capacity exceeding } 300 \mathrm{l} \text {, whether or } \\
\text { not lined or heat insulated }\end{array}$ & WAT \\
\hline 731010 & $\mathrm{H} 3$ & $\begin{array}{l}\text { Tanks, casks, drums, cans, boxes and similar containers, for any material (excluding } \\
\text { compressed or liquefied gas), } 501 \text { or more capacity but not exceeding } 300 \mathrm{l}\end{array}$ & WAT \\
\hline 731029 & $\mathrm{H} 3$ & $\begin{array}{l}\text { Tanks, casks, drums, boxes and similar containers for any material (excluding } \\
\text { compressed or liquefied gas) less than } 50 \text { capacity, n.e.c. in item no. } 7310.2 \text {, of iron } \\
\text { or steel }\end{array}$ & WAT \\
\hline 732111 & $\mathrm{H} 3$ & $\begin{array}{l}\text { Cooking appliances and plate warmers; for gas fuel or for both gas and other fuels, } \\
\text { of iron or steel }\end{array}$ & CRE \\
\hline 732119 & $\mathrm{H} 3$ & $\begin{array}{l}\text { Cooking appliances and plate warmers; for solid fuel and fuels other than gas or } \\
\text { liquid, of iron or steel }\end{array}$ & REP \\
\hline 732189 & $\mathrm{H} 3$ & $\begin{array}{l}\text { Domestic appliances; non-electric, (other than cookers and plate warmers), for solid } \\
\text { fuel and fuels other than gas or liquid, of iron or steel }\end{array}$ & REP \\
\hline 732190 & $\mathrm{H} 3$ & Domestic appliances; non-electric, parts thereof, of iron or steel & CRE \\
\hline 732490 & $\mathrm{H} 3$ & Iron or steel; sanitary ware and parts thereof, excluding sinks, wash basins and baths & WAT \\
\hline 732510 & $\mathrm{H} 3$ & Iron; articles of non-malleable cast iron & WAT \\
\hline 732690 & $\mathrm{H} 3$ & Iron or steel; articles n.e.c. in heading no. 7326 & WAT \\
\hline 761090 & $\mathrm{H} 3$ & $\begin{array}{l}\text { Aluminium; structures (excluding prefabricated buildings of heading no. 9406) and } \\
\text { parts of structures, n.e.c. in heading no. } 7610 \text {, plates, rods, profiles, tubes and the } \\
\text { like }\end{array}$ & REP \\
\hline 761100 & $\mathrm{H} 3$ & $\begin{array}{l}\text { Aluminium; reservoirs, tanks, vats and similar containers, for material (not } \\
\text { compressed or liquefied gas), of a capacity over } 300 \mathrm{l} \text {, whether or not lined, not fitted } \\
\text { with mechanical/thermal equipment }\end{array}$ & REP \\
\hline 761290 & $\mathrm{H} 3$ & $\begin{array}{l}\text { Aluminium; casks, drums, cans, boxes and the like for any material (not compressed } \\
\text { or liquefied gas), } 300 \text { capacity or less, whether or not lined or heat-insulated, no } \\
\text { mechanical or thermal equipment }\end{array}$ & SWM \\
\hline 830630 & $\mathrm{H} 3$ & Photograph, picture or similar frames, mirrors; of base metal & REP \\
\hline 840219 & $\mathrm{H} 3$ & Boilers; vapour generating boilers, including hybrid boilers n.e.c. in heading no. 8402 & SWM \\
\hline 840290 & $\mathrm{H} 3$ & Boilers; parts of steam or other vapour generating boilers & SWM \\
\hline 840410 & $\mathrm{H} 3$ & $\begin{array}{l}\text { Boilers; auxiliary plant, for use with boilers of heading no. } 8402 \text { or } 8403 \text { (e.g. } \\
\text { economisers, super-heaters, soot removers, gas recoverers) }\end{array}$ & APC \\
\hline 840420 & $\mathrm{H} 3$ & Boilers; condensers, for steam or other vapour power units & APC \\
\hline 840490 & $\mathrm{H} 3$ & $\begin{array}{l}\text { Boilers; parts of auxiliary plant, for use with boilers of heading no. } 8402 \text { and } 8403 \\
\text { and parts of condensers for steam or other vapour power units }\end{array}$ & APC \\
\hline
\end{tabular}




\begin{tabular}{|c|c|c|c|}
\hline 840510 & $\mathrm{H} 3$ & $\begin{array}{l}\text { Generators; producer gas, water gas, acetylene gas and similar water process gas } \\
\text { generators, with or without their purifiers }\end{array}$ & APC \\
\hline 840681 & $\mathrm{H} 3$ & $\begin{array}{l}\text { Turbines; steam and other vapour turbines, (for other than marine propulsion), of an } \\
\text { output exceeding } 40 \mathrm{MW}\end{array}$ & REP \\
\hline 840682 & $\mathrm{H} 3$ & $\begin{array}{l}\text { Turbines; steam and other vapour turbines, (for other than marine propulsion), of an } \\
\text { output not exceeding } 40 \mathrm{MW}\end{array}$ & REP \\
\hline 840690 & $\mathrm{H} 3$ & Turbines; parts of steam and other vapour turbines & REP \\
\hline 840991 & $\mathrm{H} 3$ & $\begin{array}{l}\text { Engines; parts, suitable for use solely or principally with spark-ignition internal } \\
\text { combustion piston engines (for other than aircraft) }\end{array}$ & NVA \\
\hline 840999 & H3 & Engines; parts for internal combustion piston engines (excluding spark-ignition) & NVA \\
\hline 841011 & $\mathrm{H} 3$ & Turbines; hydraulic turbines and water wheels, of a power not exceeding $1000 \mathrm{~kW}$ & REP \\
\hline 841012 & $\mathrm{H} 3$ & $\begin{array}{l}\text { Turbines; hydraulic turbines and water wheels, of a power exceeding } 1000 \mathrm{~kW} \text { but } \\
\text { not exceeding } 10000 \mathrm{~kW}\end{array}$ & REP \\
\hline 841013 & $\mathrm{H} 3$ & Turbines; hydraulic turbines and water wheels, of a power exceeding $10000 \mathrm{~kW}$ & REP \\
\hline 841090 & $\mathrm{H} 3$ & Turbines; parts of hydraulic turbines and water wheels, including regulators & REP \\
\hline 841181 & H3 & $\begin{array}{l}\text { Turbines; gas-turbines (excluding turbo-jets and turbo-propellers), of a power not } \\
\text { exceeding } 5000 \mathrm{~kW}\end{array}$ & REP \\
\hline 841182 & $\mathrm{H} 3$ & $\begin{array}{l}\text { Turbines; gas-turbines (excluding turbo-jets and turbo-propellers), of a power } \\
\text { exceeding } 5000 \mathrm{~kW}\end{array}$ & REP \\
\hline 841199 & $\mathrm{H} 3$ & Turbines; parts of gas turbines (excluding turbo-jets and turbo-propellers) & REP \\
\hline 841280 & $\mathrm{H} 3$ & Engines; pneumatic power engines and motors, n.e.c. in heading no. 8412 & REP \\
\hline 841290 & $\mathrm{H} 3$ & Engines; parts, for engines and motors of heading no. 8412 & REP \\
\hline 841320 & $\mathrm{H} 3$ & $\begin{array}{l}\text { Pumps; hand, fitted or designed to be fitted with a measuring device, for liquids, other } \\
\text { than those of item no. } 8413.11 \text { or } 8413.19\end{array}$ & WAT \\
\hline 841350 & $\mathrm{H} 3$ & $\begin{array}{l}\text { Pumps; reciprocating positive displacement pumps, n.e.c. in heading no. } 8413 \text {, for } \\
\text { liquids }\end{array}$ & WAT \\
\hline 841360 & $\mathrm{H} 3$ & Pumps; rotary positive displacement pumps, n.e.c. in heading no. 8413 , for liquids & WAT \\
\hline 841370 & $\mathrm{H} 3$ & Pumps; centrifugal, n.e.c. in heading no. 8413 , for liquids & WAT \\
\hline 841381 & $\mathrm{H} 3$ & Pumps and liquid elevators; n.e.c. in heading no. 8413 & WAT \\
\hline 841410 & $\mathrm{H} 3$ & Pumps; vacuum & APC \\
\hline 841430 & H3 & Compressors; of a kind used in refrigerating equipment & APC \\
\hline 841440 & H3 & Compressors; air compressors mounted on a wheeled chassis for towing & APC \\
\hline 841459 & $\mathrm{H} 3$ & Fans; n.e.c. in item no. 8414.51 & APC \\
\hline 841480 & $\mathrm{H} 3$ & Pumps and compressors; for air, vacuum or gas, n.e.c. in heading no. 8414 & APC \\
\hline 841490 & $\mathrm{H} 3$ & $\begin{array}{l}\text { Pumps and compressors; parts, of air or vacuum pumps, air or other gas } \\
\text { compressors and fans, ventilating or recycling hoods incorporating a fan }\end{array}$ & APC \\
\hline 841581 & $\mathrm{H} 3$ & $\begin{array}{l}\text { Air conditioning machines; containing a motor driven fan, other than window or wall } \\
\text { types, incorporating a refrigerating unit and a valve for reversal of the cooling/heat } \\
\text { cycle (reversible heat pumps) }\end{array}$ & REP \\
\hline 841780 & $\mathrm{H} 3$ & $\begin{array}{l}\text { Furnaces and ovens; including incinerators, non-electric, for industrial or laboratory } \\
\text { use, n.e.c. in heading no. } 8417\end{array}$ & SWM \\
\hline 841790 & $\mathrm{H} 3$ & $\begin{array}{l}\text { Furnaces and ovens; parts of non-electric furnaces and ovens (including } \\
\text { incinerators), of industrial or laboratory use }\end{array}$ & SWM \\
\hline 841861 & $\mathrm{H} 3$ & Heat pumps; other than air conditioning machines of heading no. 8415 & REP \\
\hline 841869 & $\mathrm{H} 3$ & Refrigerating or freezing equipment; n.e.c. in heading no. 8418 & REP \\
\hline 841919 & $\mathrm{H} 3$ & $\begin{array}{l}\text { Heaters; instantaneous or storage water heaters, non-electric, other than } \\
\text { instantaneous gas water heaters }\end{array}$ & REP \\
\hline 841939 & $\mathrm{H} 3$ & Dryers; for products n.e.c. in heading no. 8419 , not used for domestic purposes & WAT \\
\hline 841940 & $\mathrm{H} 3$ & Distilling or rectifying plant; not used for domestic purposes & SWM \\
\hline 841950 & $\mathrm{H} 3$ & Heat exchange units; not used for domestic purposes & HEM \\
\hline 841960 & $\mathrm{H} 3$ & Machinery; for liquefying air or gas, not used for domestic purposes & APC \\
\hline 841989 & $\mathrm{H} 3$ & $\begin{array}{l}\text { Machinery, plant and laboratory equipment; for treating materials by change of } \\
\text { temperature, other than for making hot drinks or cooking or heating food }\end{array}$ & WAT \\
\hline 841990 & H3 & $\begin{array}{l}\text { Machinery, plant and laboratory equipment; parts of equipment for treating materials } \\
\text { by a process involving a change of temperature }\end{array}$ & REP \\
\hline 842119 & $\mathrm{H} 3$ & $\begin{array}{l}\text { Centrifuges; n.e.c. in heading no. } 8421 \text {, including centrifugal dryers (but not clothes- } \\
\text { dryers) }\end{array}$ & SWR \\
\hline
\end{tabular}




\begin{tabular}{|c|c|c|c|}
\hline 842121 & $\mathrm{H} 3$ & Machinery; for filtering or purifying water & WAT \\
\hline 842129 & H3 & Machinery; for filtering or purifying liquids, n.e.c. in item no. 8421.2 & WAT \\
\hline 842139 & $\mathrm{H} 3$ & $\begin{array}{l}\text { Machinery; for filtering or purifying gases, other than intake air filters for internal } \\
\text { combustion engines }\end{array}$ & APC \\
\hline 842191 & $\mathrm{H} 3$ & Centrifuges; parts thereof, including parts for centrifugal dryers & SWR \\
\hline 842199 & $\mathrm{H} 3$ & Machinery; parts for filtering or purifying liquids or gases & WAT \\
\hline 842220 & $\mathrm{H} 3$ & Machinery; for cleaning or drying bottles or other containers & SWM \\
\hline 842290 & $\mathrm{H} 3$ & Machinery; parts of machinery of heading no. 8422 & SWM \\
\hline 842833 & H3 & $\begin{array}{l}\text { Elevators and conveyors; continuous-action, for goods or materials, belt type, n.e.c. } \\
\text { in item no. } 8428.20 \text { or } 8428.31\end{array}$ & SWM \\
\hline 842940 & H3 & Tamping machines and road rollers; self-propelled & SWM \\
\hline 846291 & H3 & $\begin{array}{l}\text { Machine-tools; presses for working metal or metal carbides, n.e.c. in heading no. } \\
8462 \text {, hydraulic presses }\end{array}$ & SWM \\
\hline 846596 & $\mathrm{H} 3$ & $\begin{array}{l}\text { Machine-tools; splitting, slicing or paring machines, for working wood, cork, bone, } \\
\text { hard rubber, hard plastics or similar hard materials }\end{array}$ & SWM \\
\hline 846599 & $\mathrm{H} 3$ & $\begin{array}{l}\text { Machine-tools; for working wood, cork, bone, hard rubber, hard plastics or similar } \\
\text { hard materials, n.e.c. in heading no. } 8465\end{array}$ & SWM \\
\hline 846694 & $\mathrm{H} 3$ & $\begin{array}{l}\text { Machine-tools; parts and accessories, for the machines of heading no. } 8462 \text { or } 8463 \text {, } \\
\text { n.e.c. in heading no. } 8466\end{array}$ & SWM \\
\hline 847420 & $\mathrm{H} 3$ & Machines; for crushing or grinding earth, stone, ores or other mineral substances & SWM \\
\hline 847982 & H3 & $\begin{array}{l}\text { Machines; for mixing, kneading, crushing, grinding, screening, sifting, homogenising, } \\
\text { emulsifying or stirring }\end{array}$ & SWM \\
\hline 847989 & H3 & $\begin{array}{l}\text { Machines and mechanical appliances; having individual functions, n.e.c. or included } \\
\text { in this chapter }\end{array}$ & SWM \\
\hline 847990 & $\mathrm{H} 3$ & Machines and mechanical appliances; parts, of those having individual functions & SWM \\
\hline 848110 & $\mathrm{H} 3$ & Valves; pressure reducing, for pipes, boiler shells, tanks, vats or the like & WAT \\
\hline 848130 & $\mathrm{H} 3$ & Valves; check (nonreturn) valves, for pipes, boiler shells, tanks, vats or the like & WAT \\
\hline 848140 & $\mathrm{H} 3$ & Valves; safety or relief valves, for pipes, boiler shells, tanks, vats or the like & WAT \\
\hline 848180 & H3 & $\begin{array}{l}\text { Taps, cocks, valves and similar appliances; for pipes, boiler shells, tanks, vats or the } \\
\text { like, including thermostatically controlled valves }\end{array}$ & WAT \\
\hline 848190 & H3 & Taps, cocks, valves and similar appliances; parts thereof & WAT \\
\hline 848340 & H3 & $\begin{array}{l}\text { Gears and gearing; (not toothed wheels, chain sprockets and other transmission } \\
\text { elements presented separately); ball or roller screws; gear boxes and other speed } \\
\text { changers, including torque converters }\end{array}$ & REP \\
\hline 848360 & $\mathrm{H} 3$ & Clutches and shaft couplings (including universal joints) & REP \\
\hline 850161 & $\mathrm{H} 3$ & Generators; AC generators, (alternators), of an output not exceeding 75kVA & REP \\
\hline 850162 & H3 & $\begin{array}{l}\text { Electric generators; AC generators, (alternators), of an output exceeding } 75 \mathrm{kVA} \text { but } \\
\text { not exceeding } 375 \mathrm{kVA}\end{array}$ & REP \\
\hline 850163 & $\mathrm{H} 3$ & $\begin{array}{l}\text { Electric generators; AC generators, (alternators), of an output exceeding } 375 \mathrm{kVA} \text { but } \\
\text { not exceeding } 750 \mathrm{kVA}\end{array}$ & REP \\
\hline 850164 & $\mathrm{H} 3$ & Electric generators; AC generators, (alternators), of an output exceeding 750kVA & REP \\
\hline 850220 & $\mathrm{H} 3$ & Electric generating sets; with spark-ignition internal combustion piston engines & HEM \\
\hline 850231 & $\mathrm{H} 3$ & $\begin{array}{l}\text { Electric generating sets; wind-powered, (excluding those with spark-ignition or } \\
\text { compression-ignition internal combustion piston engines) }\end{array}$ & REP \\
\hline 850239 & $\mathrm{H} 3$ & $\begin{array}{l}\text { Electric generating sets; (excluding those with spark-ignition or compression-ignition } \\
\text { internal combustion piston engines), other than wind powered }\end{array}$ & REP \\
\hline 850300 & $\mathrm{H} 3$ & $\begin{array}{l}\text { Electric motors and generators; parts suitable for use solely or principally with the } \\
\text { machines of heading no. } 8501 \text { or } 8502\end{array}$ & REP \\
\hline 850421 & $\mathrm{H} 3$ & $\begin{array}{l}\text { Electrical transformers; liquid dielectric, having a power handling capacity not } \\
\text { exceeding } 650 \mathrm{kVA}\end{array}$ & REP \\
\hline 850422 & $\mathrm{H} 3$ & $\begin{array}{l}\text { Electrical transformers; liquid dielectric, having a power handling capacity exceeding } \\
650 \mathrm{kVA} \text { but not exceeding } 10,000 \mathrm{kVA}\end{array}$ & REP \\
\hline 850423 & $\mathrm{H} 3$ & $\begin{array}{l}\text { Electrical transformers; liquid dielectric, having a power handling capacity exceeding } \\
\text { 10,000kVA }\end{array}$ & REP \\
\hline 850431 & $\mathrm{H} 3$ & $\begin{array}{l}\text { Electrical transformers; n.e.c. in item no. 8504.2, having a power handling capacity } \\
\text { not exceeding } 1 \mathrm{kVA}\end{array}$ & REP \\
\hline
\end{tabular}




\begin{tabular}{|c|c|c|c|}
\hline 850432 & H3 & $\begin{array}{l}\text { Transformers; n.e.c. in item no. 8504.2, having a power handling capacity exceeding } \\
\text { 1kVA but not exceeding 16kVA }\end{array}$ & REP \\
\hline 850433 & $\mathrm{H} 3$ & $\begin{array}{l}\text { Transformers; n.e.c. in item no. } 8504.2 \text {, having a power handling capacity exceeding } \\
16 \mathrm{kVA} \text { but not exceeding } 500 \mathrm{kVA}\end{array}$ & REP \\
\hline 850434 & $\mathrm{H} 3$ & $\begin{array}{l}\text { Transformers; n.e.c. in item no. } 8504.2 \text {, having a power handling capacity exceeding } \\
500 \mathrm{kVA}\end{array}$ & REP \\
\hline 850440 & $\mathrm{H} 3$ & Electrical static converters & REP \\
\hline 850490 & $\mathrm{H} 3$ & Electrical transformers, static converters and inductors; parts thereof & REP \\
\hline 850590 & $\mathrm{H} 3$ & Magnets; electro-magnets, holding devices and parts n.e.c. in heading no. 8505 & SWM \\
\hline 850680 & $\mathrm{H} 3$ & $\begin{array}{l}\text { Cells and batteries; primary, (other than manganese dioxide, mercuric oxide, silver } \\
\text { oxide, lithium or air-zinc) }\end{array}$ & CRE \\
\hline 850720 & H3 & $\begin{array}{l}\text { Electric accumulators; lead-acid, (other than for starting piston engines), including } \\
\text { separators, whether or not rectangular (including square) }\end{array}$ & REP \\
\hline 850980 & H3 & $\begin{array}{l}\text { Electro-mechanical domestic appliances; with self-contained electric motor, other } \\
\text { than vacuum cleaners of heading } 85.08 \text {, n.e.c. in heading no. } 8509\end{array}$ & CRE \\
\hline 851410 & $\mathrm{H} 3$ & Furnaces and ovens; electric, for industrial or laboratory use, resistance heated & SWM \\
\hline 851420 & $\mathrm{H} 3$ & $\begin{array}{l}\text { Furnaces and ovens; electric, for industrial or laboratory use, functioning by induction } \\
\text { or dielectric loss }\end{array}$ & SWM \\
\hline 851430 & $\mathrm{H} 3$ & $\begin{array}{l}\text { Furnaces and ovens; electric, for industrial or laboratory use, other than those } \\
\text { functioning by induction, dielectric loss or resistance heated }\end{array}$ & SWM \\
\hline 851490 & $\mathrm{H} 3$ & $\begin{array}{l}\text { Furnaces, ovens and heating equipment; parts of the industrial or laboratory } \\
\text { equipment of heading no. } 8514\end{array}$ & SWM \\
\hline 851629 & H3 & $\begin{array}{l}\text { Heating apparatus; electric soil heating apparatus and space heating apparatus } \\
\text { (excluding storage heating radiators) }\end{array}$ & SWR \\
\hline 853010 & H3 & $\begin{array}{l}\text { Signalling, safety or traffic control equipment; for railways or tramways (excluding } \\
\text { those of heading no. 8608) }\end{array}$ & CRE \\
\hline 853080 & $\mathrm{H} 3$ & $\begin{array}{l}\text { Signalling, safety or traffic control equipment; for roads, inland waterways, parking } \\
\text { facilities, port installations or airfields (excluding those of heading no. 8608) }\end{array}$ & CRE \\
\hline 853090 & $\mathrm{H} 3$ & $\begin{array}{l}\text { Signalling apparatus; parts of safety, traffic control equipment for railways, tramways, } \\
\text { roads, inland waterways, airfields, parking facilities, port instalments (excluding } \\
\text { those of heading no. 8608) }\end{array}$ & CRE \\
\hline 853710 & H3 & $\begin{array}{l}\text { Boards, panels, consoles, desks and other bases; for electric control or the } \\
\text { distribution of electricity, (other than switching apparatus of heading no. 8517), for a } \\
\text { voltage not exceeding } 1000 \text { volts }\end{array}$ & REP \\
\hline 853720 & H3 & $\begin{array}{l}\text { Boards, panels, consoles, desks and other bases; for electric control or the } \\
\text { distribution of electricity, (other than switching apparatus of heading no. } 8517 \text { ), for a } \\
\text { voltage exceeding } 1000 \text { volts }\end{array}$ & REP \\
\hline 853921 & H3 & Lamps; filament, (excluding ultra-violet or infra-red), tungsten halogen & HEM \\
\hline 853931 & $\mathrm{H} 3$ & Lamps; discharge, (excluding ultra-violet), fluorescent, hot cathode & HEM \\
\hline 853932 & H3 & $\begin{array}{l}\text { Lamps; discharge, (excluding ultra-violet), mercury or sodium vapour lamps, metal } \\
\text { halide lamps }\end{array}$ & HEM \\
\hline 854140 & $\mathrm{H} 3$ & $\begin{array}{l}\text { Electrical apparatus; photosensitive, including photovoltaic cells, whether or not } \\
\text { assembled in modules or made up into panels, light emitting diodes }\end{array}$ & REP \\
\hline 854370 & $\mathrm{H} 3$ & $\begin{array}{l}\text { Electrical machines and apparatus; having individual functions, not specified or } \\
\text { included elsewhere in this chapter, n.e.c. in heading no. } 8543\end{array}$ & WAT \\
\hline 854390 & $\mathrm{H} 3$ & Electrical machines and apparatus; parts of the electrical goods of heading no. 8543 & WAT \\
\hline 860110 & H3 & Rail locomotives; powered from an external source of electricity & CRE \\
\hline 860120 & H3 & Rail locomotives; powered by electric accumulators & CRE \\
\hline 860210 & $\mathrm{H} 3$ & Rail locomotives; diesel-electric powered & CRE \\
\hline 860290 & $\mathrm{H} 3$ & Rail locomotives and locomotive tenders; other than diesel-electric powered & CRE \\
\hline 860310 & $\mathrm{H} 3$ & $\begin{array}{l}\text { Railway or tramway coaches, vans and trucks; self-propelled, powered from an } \\
\text { external source of electricity (excluding those of heading no. 8604) }\end{array}$ & CRE \\
\hline 860390 & $\mathrm{H} 3$ & $\begin{array}{l}\text { Railway or tramway coaches, vans and trucks; self-propelled, powered other than } \\
\text { from an external source of electricity (excluding those of heading no. 8604) }\end{array}$ & CRE \\
\hline 860400 & H3 & $\begin{array}{l}\text { Railway or tramway maintenance or service vehicles; whether or not self-propelled } \\
\text { (e.g. workshops, cranes, ballast tampers, trackliners, testing coaches and track } \\
\text { inspection vehicles) }\end{array}$ & CRE \\
\hline
\end{tabular}




\begin{tabular}{|c|c|c|c|}
\hline 860500 & $\mathrm{H} 3$ & $\begin{array}{l}\text { Railway or tramway coaches; passenger coaches, luggage vans, post office coaches } \\
\text { and other special purpose railway or tramway coaches, not self-propelled (excluding } \\
\text { those of heading no. 8604) }\end{array}$ & CRE \\
\hline 860610 & $\mathrm{H} 3$ & $\begin{array}{l}\text { Railway or tramway goods vans and wagons; tank wagons and the like, not self- } \\
\text { propelled }\end{array}$ & CRE \\
\hline 860630 & H3 & $\begin{array}{l}\text { Railway or tramway goods vans and wagons; self-discharging, not self-propelled, } \\
\text { excluding those of item no. } 8606.10\end{array}$ & CRE \\
\hline 860691 & $\mathrm{H} 3$ & Railway or tramway goods vans and wagons; covered and closed, not self-propelled & CRE \\
\hline 860692 & $\mathrm{H} 3$ & $\begin{array}{l}\text { Railway or tramway goods vans and wagons; open, with non-removable sides of a } \\
\text { height exceeding } 60 \mathrm{~cm} \text {, not self-propelled }\end{array}$ & CRE \\
\hline 860699 & $\mathrm{H} 3$ & $\begin{array}{l}\text { Railway or tramway goods vans and wagons; n.e.c. in heading no. } 8606 \text {, not self- } \\
\text { propelled }\end{array}$ & CRE \\
\hline 860711 & $\mathrm{H} 3$ & $\begin{array}{l}\text { Railway or tramway locomotives or rolling stock; parts, driving bogies and bissel- } \\
\text { bogies }\end{array}$ & CRE \\
\hline 860712 & $\mathrm{H} 3$ & $\begin{array}{l}\text { Railway or tramway locomotives or rolling stock; parts, bogies and bissel-bogies } \\
\text { (excluding driving bogies and bissel-bogies) }\end{array}$ & CRE \\
\hline 860719 & $\mathrm{H} 3$ & $\begin{array}{l}\text { Railway or tramway locomotives or rolling stock; parts, axles and wheels, and parts } \\
\text { thereof }\end{array}$ & CRE \\
\hline 860721 & $\mathrm{H} 3$ & Railway or tramway locomotives or rolling stock; parts, air brakes and parts thereof & CRE \\
\hline 860729 & $\mathrm{H} 3$ & $\begin{array}{l}\text { Railway or tramway locomotives or rolling stock; parts, brakes (other than air brakes) } \\
\text { and parts thereof }\end{array}$ & CRE \\
\hline 860730 & $\mathrm{H} 3$ & $\begin{array}{l}\text { Railway or tramway locomotives or rolling stock; parts, hooks and other coupling } \\
\text { devices, buffers and parts thereof }\end{array}$ & CRE \\
\hline 860791 & $\mathrm{H} 3$ & Railway or tramway locomotives; parts n.e.c. in heading no. 8607 & CRE \\
\hline 860799 & $\mathrm{H} 3$ & Railway or tramway rolling stock; parts n.e.c. in heading no. 8607 & CRE \\
\hline 860800 & $\mathrm{H} 3$ & $\begin{array}{l}\text { Railway or tramway track fixtures and fittings; mechanical (including electro- } \\
\text { mechanical) signalling, safety or traffic control equipment for railways, tramways, } \\
\text { roads, inland waterways, parking facilities, port installations or airfields; parts thereof }\end{array}$ & CRE \\
\hline 870290 & $\mathrm{H} 3$ & $\begin{array}{l}\text { Vehicles; public transport type (carries } 10 \text { or more passengers), other than } \\
\text { compression-ignition internal combustion piston engine (diesel or semi-diesel) }\end{array}$ & CRE \\
\hline 870390 & $\mathrm{H} 3$ & $\begin{array}{l}\text { Vehicles; for transport of persons (other than those of heading no. 8702) n.e.c. in } \\
\text { heading no. } 8703 \text {, including station wagons and racing cars }\end{array}$ & CRE \\
\hline 871200 & H3 & Bicycles and other cycles; including delivery tricycles, not motorised & CRE \\
\hline 871411 & H3 & Motorcycles (including mopeds); parts, saddles & CRE \\
\hline 871419 & $\mathrm{H} 3$ & Motorcycles (including mopeds); parts, other than saddles & CRE \\
\hline 871420 & $\mathrm{H} 3$ & Carriages for disabled persons; parts and accessories thereof & CRE \\
\hline 871491 & $\mathrm{H} 3$ & Cycles; frames and forks, and parts thereof & CRE \\
\hline 871492 & $\mathrm{H} 3$ & Cycles; parts thereof, wheel rims and spokes & CRE \\
\hline 871493 & H3 & $\begin{array}{l}\text { Cycles; parts thereof, hubs (other than coaster braking hubs and hubbrakes), and } \\
\text { free-wheel sprocket-wheels }\end{array}$ & CRE \\
\hline 871494 & H3 & $\begin{array}{l}\text { Cycles; parts thereof, brakes, including coaster braking hubs and hub-brakes, and } \\
\text { parts thereof }\end{array}$ & CRE \\
\hline 871495 & $\mathrm{H} 3$ & Cycles; parts thereof, saddles & CRE \\
\hline 871496 & $\mathrm{H} 3$ & Cycles; parts, pedals and crank-gear, and parts thereof & CRE \\
\hline 871499 & $\mathrm{H} 3$ & Cycles; parts thereof, n.e.c. in item no. 8714.9 & CRE \\
\hline 871639 & $\mathrm{H} 3$ & Trailers and semi-trailers; (other than tanker type) & CRE \\
\hline 890790 & $\mathrm{H} 3$ & Floating structures; tanks, coffer-dams, landing stages, buoys and beacons & SWR \\
\hline 900190 & H3 & $\begin{array}{l}\text { Optical elements; lenses n.e.c. in heading no. } 9001 \text {, prisms, mirrors and other optical } \\
\text { elements, unmounted, of any material (excluding elements of glass not optically } \\
\text { worked) }\end{array}$ & REP \\
\hline 900290 & H3 & $\begin{array}{l}\text { Optical elements; n.e.c. in heading no. } 9002 \text { (e.g. prisms and mirrors), mounted, } \\
\text { being parts or fittings for instruments or apparatus, of any material (excluding } \\
\text { elements of glass not optically worked) }\end{array}$ & REP \\
\hline 900580 & H3 & $\begin{array}{l}\text { Monoculars; other optical telescopes and astronomical instruments, excluding } \\
\text { instruments for radio-astronomy }\end{array}$ & MON \\
\hline 901380 & $\mathrm{H} 3$ & $\begin{array}{l}\text { Optical devices, appliances and instruments; n.e.c. in heading no. } 9013 \text { (including } \\
\text { liquid crystal devices) }\end{array}$ & REP \\
\hline
\end{tabular}




\begin{tabular}{|c|c|c|c|}
\hline 901390 & $\mathrm{H} 3$ & $\begin{array}{l}\text { Optical appliances and instruments; parts and accessories for articles of heading no. } \\
9013\end{array}$ & REP \\
\hline 901530 & H3 & Surveying equipment; levels & MON \\
\hline 901540 & $\mathrm{H} 3$ & Surveying equipment; photogrammetrical surveying instruments and appliances & MON \\
\hline 901580 & H3 & $\begin{array}{l}\text { Surveying equipment; articles n.e.c. in heading no. } 9015 \text {, including hydrographic, } \\
\text { oceanographic, hydrological, meteorological or geophysical instruments and } \\
\text { appliances (excluding compasses) }\end{array}$ & MON \\
\hline 901590 & $\mathrm{H} 3$ & Surveying equipment; parts and accessories for articles of heading no. 9015 & MON \\
\hline 902511 & $\mathrm{H} 3$ & $\begin{array}{l}\text { Thermometers and pyrometers; liquid filled, for direct reading, not combined with } \\
\text { other instruments }\end{array}$ & MON \\
\hline 902519 & $\mathrm{H} 3$ & $\begin{array}{l}\text { Thermometers and pyrometers; (other than liquid filled, for direct reading), not } \\
\text { combined with other instruments }\end{array}$ & MON \\
\hline 902610 & $\mathrm{H} 3$ & Instruments and apparatus; for measuring or checking the flow or level of liquids & MON \\
\hline 902620 & $\mathrm{H} 3$ & Instruments and apparatus; for measuring or checking pressure & MON \\
\hline 902680 & $\mathrm{H} 3$ & $\begin{array}{l}\text { Instruments and apparatus; for measuring or checking variables of liquids or gases } \\
\text { (excluding pressure or the flow and level of liquids and those of heading no. } 9014 \text {, } \\
9015,9028 \text { and 9032) }\end{array}$ & MON \\
\hline 902690 & $\mathrm{H} 3$ & $\begin{array}{l}\text { Instruments and apparatus; parts and accessories for those measuring or checking } \\
\text { the flow, level, pressure or other variables of liquids or gases (excluding those of } \\
\text { heading no. } 9014,9015,9028 \text { or } 9032 \text { ) }\end{array}$ & MON \\
\hline 902710 & H3 & $\begin{array}{l}\text { Instruments and apparatus; gas or smoke analysis apparatus, for physical or } \\
\text { chemical analysis }\end{array}$ & MON \\
\hline 902720 & H3 & Chromatographs and electrophoresis instruments & MON \\
\hline 902730 & $\mathrm{H} 3$ & $\begin{array}{l}\text { Spectrometers, spectrophotometers and spectrographs; using optical radiations } \\
\text { (UV, visible, IR) }\end{array}$ & MON \\
\hline 902750 & $\mathrm{H} 3$ & $\begin{array}{l}\text { Instruments and apparatus; using optical radiations (UV, visible, IR), (other than } \\
\text { spectrometers, spectrophotometers and spectrographs) }\end{array}$ & MON \\
\hline 902780 & $\mathrm{H} 3$ & $\begin{array}{l}\text { Instruments and apparatus; for physical or chemical analysis, for measuring or } \\
\text { checking viscosity, porosity, expansion, surface tension or quantities of heat, sound } \\
\text { or light, n.e.c. in heading no. } 9027\end{array}$ & MON \\
\hline 902790 & H3 & Microtomes and parts and accessories thereof & MON \\
\hline 902810 & H3 & Meters; gas, supply or production meters, including calibrating meters thereof & MON \\
\hline 902820 & H3 & Meters; liquid supply or production meters, including calibrating meters thereof & MON \\
\hline 902830 & $\mathrm{H} 3$ & Meters; electricity supply or production meters, including calibrating meters thereof & HEM \\
\hline 902890 & $\mathrm{H} 3$ & $\begin{array}{l}\text { Meters; parts and accessories of gas, liquid, electricity supply or production meters, } \\
\text { including calibrating meters thereof }\end{array}$ & HEM \\
\hline 903010 & $\mathrm{H} 3$ & Instruments and apparatus; for measuring or detecting ionising radiations & MON \\
\hline 903020 & $\mathrm{H} 3$ & Oscilloscopes and oscillographs & MON \\
\hline 903031 & H3 & $\begin{array}{l}\text { Multimeters; for measuring or checking voltage, current, resistance or power, without } \\
\text { a recording device }\end{array}$ & MON \\
\hline 903032 & $\mathrm{H} 3$ & $\begin{array}{l}\text { Multimeters; for measuring or checking voltage, current, resistance or power, with a } \\
\text { recording device }\end{array}$ & MON \\
\hline 903033 & $\mathrm{H} 3$ & $\begin{array}{l}\text { Instruments and apparatus; for measuring or checking voltage, current, resistance } \\
\text { or power, without a recording device (excluding multimeters) }\end{array}$ & MON \\
\hline 903039 & $\mathrm{H} 3$ & $\begin{array}{l}\text { Instruments and apparatus; for measuring or checking voltage, current, resistance } \\
\text { or power, with a recording device (excluding multimeters) }\end{array}$ & MON \\
\hline 903084 & $\mathrm{H} 3$ & Instruments and apparatus; n.e.c. in heading no. 9030 , with a recording device & MON \\
\hline 903089 & $\mathrm{H} 3$ & Instruments and apparatus; n.e.c. in heading no. 9030, without a recording device & MON \\
\hline 903090 & $\mathrm{H} 3$ & $\begin{array}{l}\text { Instruments, apparatus for measuring, checking electrical quantities, not meters of } \\
\text { heading no. 9028; parts and accessories, for measuring or detecting alpha, beta, } \\
\text { gamma, x-ray, cosmic and other radiations }\end{array}$ & MON \\
\hline 903110 & H3 & Machines; for balancing mechanical parts & NVA \\
\hline 903120 & H3 & Test benches & MON \\
\hline 903149 & $\mathrm{H} 3$ & Optical instruments and appliances; for measuring or checking, n.e.c. in chapter 90 & MON \\
\hline 903180 & $\mathrm{H} 3$ & $\begin{array}{l}\text { Instruments, appliances and machines; for measuring or checking n.e.c. in chapter } \\
90\end{array}$ & MON \\
\hline 903190 & $\mathrm{H} 3$ & $\begin{array}{l}\text { Instruments, appliances and machines; parts and accessories for those measuring } \\
\text { or checking devices of heading no. } 9031\end{array}$ & MON \\
\hline
\end{tabular}




\begin{tabular}{|c|c|c|c|}
\hline 903210 & H3 & Regulating or controlling instruments and apparatus; automatic type, thermostats & MON \\
\hline 903220 & H3 & Regulating or controlling instruments and apparatus; automatic, manostats & MON \\
\hline 903281 & $\mathrm{H} 3$ & $\begin{array}{l}\text { Regulating or controlling instruments and apparatus; automatic, hydraulic or } \\
\text { pneumatic }\end{array}$ & MON \\
\hline 903289 & H3 & $\begin{array}{l}\text { Regulating or controlling instruments and apparatus; automatic, other than hydraulic } \\
\text { or pneumatic }\end{array}$ & REP \\
\hline 903290 & $\mathrm{H} 3$ & $\begin{array}{l}\text { Regulating or controlling instruments and apparatus; automatic, parts and } \\
\text { accessories }\end{array}$ & MON \\
\hline 903300 & $\mathrm{H} 3$ & $\begin{array}{l}\text { Machines and appliances; instruments or apparatus of chapter 90; parts and } \\
\text { accessories n.e.c. in chapter } 90\end{array}$ & MON \\
\hline 940510 & $\mathrm{H} 3$ & $\begin{array}{l}\text { Chandeliers and other electric ceiling or wall light fittings; excluding those used for } \\
\text { lighting public open spaces or thoroughfares }\end{array}$ & HEM \\
\hline 940520 & $\mathrm{H} 3$ & Lamps, electric; floor-standing or for table, desk or bedside & HEM \\
\hline 940540 & H3 & Lamps and light fittings; electric, n.e.c. in heading no. 9405 & HEM \\
\hline 950720 & $\mathrm{H} 3$ & Fish-hooks; whether or not snelled & NRP \\
\hline
\end{tabular}

Table A.5. Correspondence of the CLEG in different HS versions

\begin{tabular}{|c|c|c|c|c|c|}
\hline HS $1992(\mathrm{HO})$ & HS 1996 (H1) & HS 2002 (H2) & HS 2007 (H3) & HS $2012(\mathrm{H} 4)$ & HS 2017 (H5) \\
\hline 441830 & 441830 & 441830 & 441872 & 441872 & 441873 \\
\hline 732690 & 732690 & 732690 & 732690 & 732690 & 732690 \\
\hline 842220 & 842220 & 842220 & 842220 & 842220 & 842220 \\
\hline 842290 & 842290 & 842290 & 842290 & 842290 & 842290 \\
\hline 846596 & 846596 & 846596 & 846596 & 846596 & 846596 \\
\hline 846599 & 846599 & 846599 & 846599 & 846599 & 846599 \\
\hline 846694 & 846694 & 846694 & 846694 & 846694 & 846694 \\
\hline 847989 & 847989 & 847989 & 847989 & 847989 & 847989 \\
\hline 847990 & 847990 & 847990 & 847990 & 847990 & 847990 \\
\hline 850421 & 850421 & 850421 & 850421 & 850421 & 850421 \\
\hline 850422 & 850422 & 850422 & 850422 & 850422 & 850422 \\
\hline 850423 & 850423 & 850423 & 850423 & 850423 & 850423 \\
\hline 850431 & 850431 & 850431 & 850431 & 850431 & 850431 \\
\hline 850432 & 850432 & 850432 & 850432 & 850432 & 850432 \\
\hline 850433 & 850433 & 850433 & 850433 & 850433 & 850433 \\
\hline 850434 & 850434 & 850434 & 850434 & 850434 & 850434 \\
\hline 850440 & 850440 & 850440 & 850440 & 850440 & 850440 \\
\hline 850490 & 850490 & 850490 & 850490 & 850490 & 850490 \\
\hline 853010 & 853010 & 853010 & 853010 & 853010 & 853010 \\
\hline 853080 & 853080 & 853080 & 853080 & 853080 & 853080 \\
\hline 853090 & 853090 & 853090 & 853090 & 853090 & 853090 \\
\hline 853710 & 853710 & 853710 & 853710 & 853710 & 853710 \\
\hline 853720 & 853720 & 853720 & 853720 & 853720 & 853720 \\
\hline 854380 & 854389 & 854389 & 854370 & 854370 & 854370 \\
\hline 854390 & 854390 & 854390 & 854390 & 854390 & 854390 \\
\hline 870290 & 870290 & 870290 & 870290 & 870290 & 870240 \\
\hline 870390 & 870390 & 870390 & 870390 & 870390 & 870380 \\
\hline 901590 & 901590 & 901590 & 901590 & 901590 & 901590 \\
\hline 902511 & 902511 & 902511 & 902511 & 902511 & 902511 \\
\hline 902519 & 902519 & 902519 & 902519 & 902519 & 902519 \\
\hline 902610 & 902610 & 902610 & 902610 & 902610 & 902610 \\
\hline 902620 & 902620 & 902620 & 902620 & 902620 & 902620 \\
\hline 902680 & 902680 & 902680 & 902680 & 902680 & 902680 \\
\hline 902690 & 902690 & 902690 & 902690 & 902690 & 902690 \\
\hline
\end{tabular}




\begin{tabular}{|c|c|c|c|c|c|}
\hline 903010 & 903010 & 903010 & 903010 & 903010 & 903010 \\
\hline 903020 & 903020 & 903020 & 903020 & 903020 & 903020 \\
\hline 903031 & 903031 & 903031 & 903031 & 903031 & 903031 \\
\hline 903081 & 903083 & 903083 & 903032 & 903032 & 903032 \\
\hline 903039 & 903039 & 903039 & 903033 & 903033 & 903033 \\
\hline 903081 & 903083 & 903083 & 903039 & 903039 & 903039 \\
\hline 903081 & 903083 & 903083 & 903084 & 903084 & 903084 \\
\hline 903089 & 903089 & 903089 & 903089 & 903089 & 903089 \\
\hline 903090 & 903090 & 903090 & 903090 & 903090 & 903090 \\
\hline 903110 & 903110 & 903110 & 903110 & 903110 & 903110 \\
\hline 903120 & 903120 & 903120 & 903120 & 903120 & 903120 \\
\hline 903140 & 903149 & 903149 & 903149 & 903149 & 903149 \\
\hline 903180 & 903180 & 903180 & 903180 & 903180 & 903180 \\
\hline 903190 & 903190 & 903190 & 903190 & 903190 & 903190 \\
\hline 903210 & 903210 & 903210 & 903210 & 903210 & 903210 \\
\hline 903220 & 903220 & 903220 & 903220 & 903220 & 903220 \\
\hline 903281 & 903281 & 903281 & 903281 & 903281 & 903281 \\
\hline 903289 & 903289 & 903289 & 903289 & 903289 & 903289 \\
\hline 903290 & 903290 & 903290 & 903290 & 903290 & 903290 \\
\hline 903300 & 903300 & 903300 & 903300 & 903300 & 903300 \\
\hline 380210 & 380210 & 380210 & 380210 & 380210 & 380210 \\
\hline 390940 & 390940 & 390940 & 390940 & 390940 & 390940 \\
\hline 392010 & 392010 & 392010 & 392010 & 392010 & 392010 \\
\hline 392030 & 392030 & 392030 & 392030 & 392030 & 392030 \\
\hline 392111 & 392111 & 392111 & 392111 & 392111 & 392111 \\
\hline 392113 & 392113 & 392113 & 392113 & 392113 & 392113 \\
\hline 392510 & 392510 & 392510 & 392510 & 392510 & 392510 \\
\hline 400259 & 400259 & 400259 & 400259 & 400259 & 400259 \\
\hline 450410 & 450410 & 450410 & 450410 & 450410 & 450410 \\
\hline 450490 & 450490 & 450490 & 450490 & 450490 & 450490 \\
\hline 530310 & 530310 & 530310 & 530310 & 530310 & 530310 \\
\hline 530599 & 530599 & 530590 & 530500 & 530500 & 530500 \\
\hline 540500 & 540500 & 540500 & 540500 & 540500 & 540500 \\
\hline 560300 & 560314 & 560314 & 560314 & 560314 & 560314 \\
\hline 560721 & 560721 & 560721 & 560721 & 560721 & 560721 \\
\hline 560790 & 560790 & 560790 & 560790 & 560790 & 560790 \\
\hline 560811 & 560811 & 560811 & 560811 & 560811 & 560811 \\
\hline 560890 & 560890 & 560890 & 560890 & 560890 & 560890 \\
\hline 630510 & 630510 & 630510 & 630510 & 630510 & 630510 \\
\hline 680610 & 680610 & 680610 & 680610 & 680610 & 680610 \\
\hline 680690 & 680690 & 680690 & 680690 & 680690 & 680690 \\
\hline 680800 & 680800 & 680800 & 680800 & 680800 & 680800 \\
\hline 681011 & 681011 & 681011 & 681011 & 681011 & 681011 \\
\hline 681019 & 681019 & 681019 & 681019 & 681019 & 681019 \\
\hline 681091 & 681091 & 681091 & 681091 & 681091 & 681091 \\
\hline 691010 & 691010 & 691010 & 691010 & 691010 & 691010 \\
\hline 700800 & 700800 & 700800 & 700800 & 700800 & 700800 \\
\hline 700991 & 700991 & 700991 & 700991 & 700991 & 700991 \\
\hline 700992 & 700992 & 700992 & 700992 & 700992 & 700992 \\
\hline 701931 & 701931 & 701931 & 701931 & 701931 & 701931 \\
\hline 701939 & 701939 & 701939 & 701939 & 701939 & 701939 \\
\hline 730210 & 730210 & 730210 & 730210 & 730210 & 730210 \\
\hline 730230 & 730230 & 730230 & 730230 & 730230 & 730230 \\
\hline 730240 & 730240 & 730240 & 730240 & 730240 & 730240 \\
\hline
\end{tabular}


70 | TRENDS IN POLICY INDICATORS ON TRADE AND ENVIRONMENT

\begin{tabular}{|c|c|c|c|c|c|}
\hline 730290 & 730290 & 730290 & 730290 & 730290 & 730290 \\
\hline 730300 & 730300 & 730300 & 730300 & 730300 & 730300 \\
\hline 730431 & 730431 & 730431 & 730431 & 730431 & 730431 \\
\hline 730490 & 730490 & 730490 & 730490 & 730490 & 730490 \\
\hline 730630 & 730630 & 730630 & 730630 & 730630 & 730630 \\
\hline 730690 & 730690 & 730690 & 730690 & 730690 & 730690 \\
\hline 730820 & 730820 & 730820 & 730820 & 730820 & 730820 \\
\hline 730890 & 730890 & 730890 & 730890 & 730890 & 730890 \\
\hline 730900 & 730900 & 730900 & 730900 & 730900 & 730900 \\
\hline 731010 & 731010 & 731010 & 731010 & 731010 & 731010 \\
\hline 731029 & 731029 & 731029 & 731029 & 731029 & 731029 \\
\hline 732111 & 732111 & 732111 & 732111 & 732111 & 732111 \\
\hline 732113 & 732113 & 732113 & 732119 & 732119 & 732119 \\
\hline 732183 & 732183 & 732183 & 732189 & 732189 & 732189 \\
\hline 732190 & 732190 & 732190 & 732190 & 732190 & 732190 \\
\hline 732490 & 732490 & 732490 & 732490 & 732490 & 732490 \\
\hline 732510 & 732510 & 732510 & 732510 & 732510 & 732510 \\
\hline 761090 & 761090 & 761090 & 761090 & 761090 & 761090 \\
\hline 761100 & 761100 & 761100 & 761100 & 761100 & 761100 \\
\hline 761290 & 761290 & 761290 & 761290 & 761290 & 761290 \\
\hline 830630 & 830630 & 830630 & 830630 & 830630 & 830630 \\
\hline 840219 & 840219 & 840219 & 840219 & 840219 & 840219 \\
\hline 840290 & 840290 & 840290 & 840290 & 840290 & 840290 \\
\hline 840410 & 840410 & 840410 & 840410 & 840410 & 840410 \\
\hline 840420 & 840420 & 840420 & 840420 & 840420 & 840420 \\
\hline 840490 & 840490 & 840490 & 840490 & 840490 & 840490 \\
\hline 840510 & 840510 & 840510 & 840510 & 840510 & 840510 \\
\hline 840619 & 840681 & 840681 & 840681 & 840681 & 840681 \\
\hline 840619 & 840682 & 840682 & 840682 & 840682 & 840682 \\
\hline 840690 & 840690 & 840690 & 840690 & 840690 & 840690 \\
\hline 840991 & 840991 & 840991 & 840991 & 840991 & 840991 \\
\hline 840999 & 840999 & 840999 & 840999 & 840999 & 840999 \\
\hline 841011 & 841011 & 841011 & 841011 & 841011 & 841011 \\
\hline 841012 & 841012 & 841012 & 841012 & 841012 & 841012 \\
\hline 841013 & 841013 & 841013 & 841013 & 841013 & 841013 \\
\hline 841090 & 841090 & 841090 & 841090 & 841090 & 841090 \\
\hline 841181 & 841181 & 841181 & 841181 & 841181 & 841181 \\
\hline 841182 & 841182 & 841182 & 841182 & 841182 & 841182 \\
\hline 841199 & 841199 & 841199 & 841199 & 841199 & 841199 \\
\hline 841280 & 841280 & 841280 & 841280 & 841280 & 841280 \\
\hline 841290 & 841290 & 841290 & 841290 & 841290 & 841290 \\
\hline 841320 & 841320 & 841320 & 841320 & 841320 & 841320 \\
\hline 841350 & 841350 & 841350 & 841350 & 841350 & 841350 \\
\hline 841360 & 841360 & 841360 & 841360 & 841360 & 841360 \\
\hline 841370 & 841370 & 841370 & 841370 & 841370 & 841370 \\
\hline 841381 & 841381 & 841381 & 841381 & 841381 & 841381 \\
\hline 841410 & 841410 & 841410 & 841410 & 841410 & 841410 \\
\hline 841430 & 841430 & 841430 & 841430 & 841430 & 841430 \\
\hline 841440 & 841440 & 841440 & 841440 & 841440 & 841440 \\
\hline 841459 & 841459 & 841459 & 841459 & 841459 & 841459 \\
\hline 841480 & 841480 & 841480 & 841480 & 841480 & 841480 \\
\hline 841490 & 841490 & 841490 & 841490 & 841490 & 841490 \\
\hline 841581 & 841581 & 841581 & 841581 & 841581 & 841581 \\
\hline 841780 & 841780 & 841780 & 841780 & 841780 & 841780 \\
\hline
\end{tabular}




\begin{tabular}{|c|c|c|c|c|c|}
\hline 841790 & 841790 & 841790 & 841790 & 841790 & 841790 \\
\hline 841861 & 841861 & 841861 & 841861 & 841861 & 841861 \\
\hline 841869 & 841869 & 841869 & 841869 & 841869 & 841869 \\
\hline 841919 & 841919 & 841919 & 841919 & 841919 & 841919 \\
\hline 841939 & 841939 & 841939 & 841939 & 841939 & 841939 \\
\hline 841940 & 841940 & 841940 & 841940 & 841940 & 841940 \\
\hline 841950 & 841950 & 841950 & 841950 & 841950 & 841950 \\
\hline 841960 & 841960 & 841960 & 841960 & 841960 & 841960 \\
\hline 841989 & 841989 & 841989 & 841989 & 841989 & 841989 \\
\hline 841990 & 841990 & 841990 & 841990 & 841990 & 841990 \\
\hline 842119 & 842119 & 842119 & 842119 & 842119 & 842119 \\
\hline 842121 & 842121 & 842121 & 842121 & 842121 & 842121 \\
\hline 842129 & 842129 & 842129 & 842129 & 842129 & 842129 \\
\hline 842139 & 842139 & 842139 & 842139 & 842139 & 842139 \\
\hline 842191 & 842191 & 842191 & 842191 & 842191 & 842191 \\
\hline 842199 & 842199 & 842199 & 842199 & 842199 & 842199 \\
\hline 842833 & 842833 & 842833 & 842833 & 842833 & 842833 \\
\hline 842940 & 842940 & 842940 & 842940 & 842940 & 842940 \\
\hline 846291 & 846291 & 846291 & 846291 & 846291 & 846291 \\
\hline 847420 & 847420 & 847420 & 847420 & 847420 & 847420 \\
\hline 847982 & 847982 & 847982 & 847982 & 847982 & 847982 \\
\hline 848110 & 848110 & 848110 & 848110 & 848110 & 848110 \\
\hline 848130 & 848130 & 848130 & 848130 & 848130 & 848130 \\
\hline 848140 & 848140 & 848140 & 848140 & 848140 & 848140 \\
\hline 848180 & 848180 & 848180 & 848180 & 848180 & 848180 \\
\hline 848190 & 848190 & 848190 & 848190 & 848190 & 848190 \\
\hline 848340 & 848340 & 848340 & 848340 & 848340 & 848340 \\
\hline 848360 & 848360 & 848360 & 848360 & 848360 & 848360 \\
\hline 850161 & 850161 & 850161 & 850161 & 850161 & 850161 \\
\hline 850162 & 850162 & 850162 & 850162 & 850162 & 850162 \\
\hline 850163 & 850163 & 850163 & 850163 & 850163 & 850163 \\
\hline 850164 & 850164 & 850164 & 850164 & 850164 & 850164 \\
\hline 850220 & 850220 & 850220 & 850220 & 850220 & 850220 \\
\hline 850230 & 850231 & 850231 & 850231 & 850231 & 850231 \\
\hline 850230 & 850239 & 850239 & 850239 & 850239 & 850239 \\
\hline 850300 & 850300 & 850300 & 850300 & 850300 & 850300 \\
\hline 850590 & 850590 & 850590 & 850590 & 850590 & 850590 \\
\hline 850619 & 850680 & 850680 & 850680 & 850680 & 850680 \\
\hline 850720 & 850720 & 850720 & 850720 & 850720 & 850720 \\
\hline 850980 & 850980 & 850980 & 850980 & 850980 & 850980 \\
\hline 851410 & 851410 & 851410 & 851410 & 851410 & 851410 \\
\hline 851420 & 851420 & 851420 & 851420 & 851420 & 851420 \\
\hline 851430 & 851430 & 851430 & 851430 & 851430 & 851430 \\
\hline 851490 & 851490 & 851490 & 851490 & 851490 & 851490 \\
\hline 851629 & 851629 & 851629 & 851629 & 851629 & 851629 \\
\hline 853921 & 853921 & 853921 & 853921 & 853921 & 853921 \\
\hline 853931 & 853931 & 853931 & 853931 & 853931 & 853931 \\
\hline 853939 & 853932 & 853932 & 853932 & 853932 & 853932 \\
\hline 854140 & 854140 & 854140 & 854140 & 854140 & 854140 \\
\hline 860110 & 860110 & 860110 & 860110 & 860110 & 860110 \\
\hline 860120 & 860120 & 860120 & 860120 & 860120 & 860120 \\
\hline 860210 & 860210 & 860210 & 860210 & 860210 & 860210 \\
\hline 860290 & 860290 & 860290 & 860290 & 860290 & 860290 \\
\hline 860310 & 860310 & 860310 & 860310 & 860310 & 860310 \\
\hline
\end{tabular}




\begin{tabular}{|c|c|c|c|c|c|}
\hline 860390 & 860390 & 860390 & 860390 & 860390 & 860390 \\
\hline 860400 & 860400 & 860400 & 860400 & 860400 & 860400 \\
\hline 860500 & 860500 & 860500 & 860500 & 860500 & 860500 \\
\hline 860610 & 860610 & 860610 & 860610 & 860610 & 860610 \\
\hline 860630 & 860630 & 860630 & 860630 & 860630 & 860630 \\
\hline 860691 & 860691 & 860691 & 860691 & 860691 & 860691 \\
\hline 860692 & 860692 & 860692 & 860692 & 860692 & 860692 \\
\hline 860699 & 860699 & 860699 & 860699 & 860699 & 860699 \\
\hline 860711 & 860711 & 860711 & 860711 & 860711 & 860711 \\
\hline 860712 & 860712 & 860712 & 860712 & 860712 & 860712 \\
\hline 860719 & 860719 & 860719 & 860719 & 860719 & 860719 \\
\hline 860721 & 860721 & 860721 & 860721 & 860721 & 860721 \\
\hline 860729 & 860729 & 860729 & 860729 & 860729 & 860729 \\
\hline 860730 & 860730 & 860730 & 860730 & 860730 & 860730 \\
\hline 860791 & 860791 & 860791 & 860791 & 860791 & 860791 \\
\hline 860799 & 860799 & 860799 & 860799 & 860799 & 860799 \\
\hline 860800 & 860800 & 860800 & 860800 & 860800 & 860800 \\
\hline 871200 & 871200 & 871200 & 871200 & 871200 & 871200 \\
\hline 871411 & 871411 & 871411 & 871411 & 871410 & 871410 \\
\hline 871419 & 871419 & 871419 & 871419 & 871410 & 871410 \\
\hline 871420 & 871420 & 871420 & 871420 & 871420 & 871420 \\
\hline 871491 & 871491 & 871491 & 871491 & 871491 & 871491 \\
\hline 871492 & 871492 & 871492 & 871492 & 871492 & 871492 \\
\hline 871493 & 871493 & 871493 & 871493 & 871493 & 871493 \\
\hline 871494 & 871494 & 871494 & 871494 & 871494 & 871494 \\
\hline 871495 & 871495 & 871495 & 871495 & 871495 & 871495 \\
\hline 871496 & 871496 & 871496 & 871496 & 871496 & 871496 \\
\hline 871499 & 871499 & 871499 & 871499 & 871499 & 871499 \\
\hline 871639 & 871639 & 871639 & 871639 & 871639 & 871639 \\
\hline 890790 & 890790 & 890790 & 890790 & 890790 & 890790 \\
\hline 900190 & 900190 & 900190 & 900190 & 900190 & 900190 \\
\hline 900290 & 900290 & 900290 & 900290 & 900290 & 900290 \\
\hline 900580 & 900580 & 900580 & 900580 & 900580 & 900580 \\
\hline 901380 & 901380 & 901380 & 901380 & 901380 & 901380 \\
\hline 901390 & 901390 & 901390 & 901390 & 901390 & 901390 \\
\hline 901530 & 901530 & 901530 & 901530 & 901530 & 901530 \\
\hline 901540 & 901540 & 901540 & 901540 & 901540 & 901540 \\
\hline 901580 & 901580 & 901580 & 901580 & 901580 & 901580 \\
\hline 902710 & 902710 & 902710 & 902710 & 902710 & 902710 \\
\hline 902720 & 902720 & 902720 & 902720 & 902720 & 902720 \\
\hline 902730 & 902730 & 902730 & 902730 & 902730 & 902730 \\
\hline 902750 & 902750 & 902750 & 902750 & 902750 & 902750 \\
\hline 902780 & 902780 & 902780 & 902780 & 902780 & 902780 \\
\hline 902790 & 902790 & 902790 & 902790 & 902790 & 902790 \\
\hline 902810 & 902810 & 902810 & 902810 & 902810 & 902810 \\
\hline 902820 & 902820 & 902820 & 902820 & 902820 & 902820 \\
\hline 902830 & 902830 & 902830 & 902830 & 902830 & 902830 \\
\hline 902890 & 902890 & 902890 & 902890 & 902890 & 902890 \\
\hline 940510 & 940510 & 940510 & 940510 & 940510 & 940510 \\
\hline 940520 & 940520 & 940520 & 940520 & 940520 & 940520 \\
\hline 940540 & 940540 & 940540 & 940540 & 940540 & 940540 \\
\hline 950720 & 950720 & 950720 & 950720 & 950720 & 950720 \\
\hline
\end{tabular}

Note: The original list of codes is defined in the version $\mathrm{H} 3$ of the Harmonized System. 


\section{A4. Tariffs on environmentally-related goods}

\section{Definition}

This indicator reports the import-weighted applied tariffs on environmentally related goods as defined in the Combined List of Environmental Goods (CLEG) in percentage points for all countries between 2003 and 2016. The variables include the following:

- Country name.

- ISO code of the country.

- Year the data on trade flows were recorded.

- HS Code: The code in the Harmonized System (HS) identifying the traded good. Codes for years 2002-2008 are reported in the H2 version of the HS, codes for years 2009-2011 are reported in the H3 version of the HS, codes for years 20122016 are reported in the $\mathrm{H} 4$ version of the HS;

- Medium: Environmental medium of the good. The environmental media covered by this indicator are: $\mathrm{APC}=$ Air pollution control; $\mathrm{CRE}=$ Cleaner or more resource efficient technologies and products; EPP = Environmentally preferable products based on end use or disposal characteristics; HEM = Heat and energy management; MON = Environmental monitoring, analysis and assessment equipment; NRP = Natural resources protection; NVA $=$ Noise and vibration abatement; REP $=$ Renewable energy plant; SWM = Management of solid and hazardous waste and recycling systems; SWR = Clean up or remediation of soil and water; WAT = Waste water management and potable water treatment.

- Average Applied Tariff: Rate of the import-weighted applied tariffs on environmentally-related goods in percentage points.

- Imports value: Aggregate value of imports that were used to calculate the average applied tariff (in current USD). This value might be lower than the total volume of imports (which can be found in the indicator on "trade in environmentally-related goods") because the imports considered here are only those associated with tariffs for which values were non-missing.

\section{Concepts, interpretation and limitations}

There is no consensus on which traded goods should be considered "environmental". As explained in Section A3, the most practical list of environmentally-related goods is the Combined List of Environmental Goods (CLEG), as used in Sauvage (2014). The CLEG provides the Harmonized System (HS) 6-digit level codes of 248 products which are derived from a combination of the following three lists: i) the OECD's indicative list of more than 150 climate change-relevant goods for a plurilateral environmental goods and services (PEGS) agreement (OECD, 2010); ii) from the more than 400 environmental goods submitted by WTO members for negotiations, including the subset of 154 products proposed by the "Friends Group" for trade negotiation ${ }^{46}$ (WTO, 2009); and iii) the list of

46 The Friends Group is composed of Canada, the European Union, Japan, Korea, New Zealand, Norway, Switzerland, Chinese Taipei, and the United States. 
54 products for which reductions in tariffs have been negotiated by the Asia-Pacific Economic Cooperation (APEC) countries. ${ }^{47}$

The applied tariffs on environmentally-related goods provided by this indicator are calculated separately for each HS code by weighting the tariff applied to an import flow by the value of the latter. That is, for a given importing country, we have:

$$
\text { Tariff }_{i}=\sum_{k} \frac{\text { Import }_{k, i}}{\text { Total imports }_{i}} * \text { Tariff }_{k, i}
$$

where, Import $_{k, i}$ is the value of imports of good $i$ from country $k$, Total imports $s_{i}$ is the value of total imports of good $i$ from country $k$, and $\operatorname{Tariff}_{k, i}$ is the applied tariff on good $i$ when imported from country $k$.

The applied (import-weighted) tariff captures the actual protection the country imposes on environmentally-related goods as opposed to the non-weighted average tariff imposed on all countries. It is relevant to gauge the actual extent of (tariff) protection on environmentally-related goods across countries.

A limitation of this indicator relates to its interpretation over several points in time. An observed variation in time, e.g. a reduction, can come directly from a tariff reduction or a change in the distribution of weights (i.e. a change in the origins of trade flows) in favour of countries that face lower tariffs. Relatedly, tariff peaks and prohibitive tariffs can lead to zero trade in some goods and thus not be counted in the calculation.

\section{Sources, measurability and data quality}

The source data to calculate the volume of trade in environmentally related goods is the Base pour l'analyse du commerce international (BACI), or BACI International Trade database. ${ }^{48}$ Data on traded volumes are available from UN COMTRADE database, the repository of official international trade statistics. However, COMTRADE database is contaminated by missing values (i.e. values not reported by countries) and by discrepancies, (i.e. when the exporter and importer report two different numbers for the same trade flow).

The BACI International Trade database provides a single consistent figure for each bilateral flow that corrects these discrepancies in mirror flows. The reconciliation methodology relies on two steps. ${ }^{49}$ First, removing transport costs from reported imports since the latter are generally reported as cost, insurance and freight (CIF) as opposed to export values, which are reported free on board (FOB). Second, evaluating the accuracy of each country's reports and using it as a weight to average reported mirror flows, now cleaned of CIF rates. ${ }^{50}$

47 For a complete description of the APEC list, see: https://www.apec.org/Meeting-Papers/LeadersDeclarations/2012/2012_aelm/2012_aelm_annexC.aspx.

48 Data from BACI International Trade database can be downloaded at http://www.cepii.fr/CEPII/en/bdd_modele/presentation.asp?id=1.

49 For a complete explanation of the methodology, see Gaulier and Zignago (2010).

50 The reconciled value $(R V)$ of exporter $V_{i}$ and importer $V_{j}$ is defined as $R V=\omega * V_{i}+(1-\omega) *$ $V_{j}$, where $\omega$ is a measure of the relative quality of the reports of country $i$ compared to the reports of country $j$. 
For these reasons, the BACI database is more reliable than the raw data observed in the COMTRADE database and is therefore used to construct this indicator. Therefore, it should also be noted that numbers from this indicator can significantly differ from official data from national customs agencies, which are the main sources of COMTRADE database.

Data on tariffs come from the UNCTAD Trade Analysis Information System (TRAINS), which is a comprehensive database that provides tariff lines at the HS 6-digit level.

\section{A5. Support measures for fossil fuels}

\section{Definition}

The indicator reports the amount provided by governments to fossil fuel producers and consumers in current USD, through direct transfers and revenue forgone for 76 countries $^{51}$ between 2007 and 2015. The variables are the following:

- Country name.

- ISO code of the country considered.

- Year in which the supports were recorded (2007-2015).

- Dataset: Names of the dataset used as the source.

- Coal: The amount of producer and consumer support to the coal industry (in USD).

- Natural gas: The amount of producer and consumer support to the natural gas industry (in USD).

- Petroleum: The amount of producer and consumer support to the petroleum industry (in USD).

- Total: The total amount of support to fossil fuels (in USD). This indicator is the sum of the supports to the specific industries described above (coal, natural gas, petroleum, and electricity).

- Gross Domestic Product of the country considered.

\section{Sources, concept, interpretations and limitations}

This indicator is the aggregate estimate combining two complementary sources of information: the OECD Inventory of Support Measures for Fossil Fuels (OECD, 2018) and the IEA price-gap estimates of fossil-fuel subsidies (IEA, 2016). The source for the gross domestic product variables is the World Development Indicators.

\section{Methodology of the OECD inventory}

The OECD Inventory of Support Measures for Fossil Fuels identifies and estimates policies that support the production or consumption of fossil fuels. ${ }^{52}$ It includes direct budgetary transfers and tax expenditures that may provide a benefit or preference for fossil-fuel production or consumption relative to alternatives. Unlike direct budgetary expenditures,

51 See full list of countries in below.

52 The Inventory covers OECD countries and eight partner economies: Argentina, Brazil, China, India, Indonesia, the Russian Federation, and South Africa. 
where outlays can usually be measured, tax expenditures are estimates of the fiscal revenue that is foregone due to a particular feature of the tax system that reduces a tax rate relative to a benchmark tax rate. ${ }^{53}$ It is important to note that definitions of tax expenditures, and the benchmarks used to estimate their size, are nationally determined. Therefore, tax expenditure estimates require caution when used for international comparability of fossil fuel support.

Measures are classified by beneficiaries: individual producers (Producer Support Estimates - PSE), individual consumers (Consumer Support Estimates - CSE), or producers and consumers collectively (General Service Support Estimates - GSSE).

\section{Methodology of the IEA price-gap approach}

To estimate fossil-fuel subsidies, the IEA uses the "price gap" approach and calculates the difference between observed domestic energy prices and international reference prices (either import-parity or export-parity) accounting for transportation and distributions costs. Estimates of such "under-pricing" identify subsidies in 44 countries, mostly economies outside the OECD area.

\section{The indicator on support measures for fossil fuels: Combining the two approaches}

Measures that lower the domestic price of fossil fuels considered by the IEA mostly take place in countries outside the OECD area, while the Inventory covers OECD members and eight partner economies. In addition, IEA estimates do not capture support to producers of fossil fuels. As such, these two approaches can be considered as complementary and might be brought together under the overarching estimation framework, the OECD PSE-CSE framework.

However, potential overlapping occurs when consumption support policies identified by the Inventory - reduced VAT tax rates, exemptions or rebates, or compensation measures for producers selling fuel products below market rates-drive domestic prices below world market prices. In order to avoid double-counting when deriving an aggregate estimate from both the Inventory and the IEA estimates while avoiding over 2010-2015 - the period during which the data coverage is the largest for most countries in both databases - the methodology used is as follows.

\footnotetext{
${ }^{53}$ In other words, tax expenditures are provisions of tax law, regulation or practices that reduce or postpone revenue for a comparatively narrow population of taxpayers relative to a benchmark tax. An in depth discussion of tax expenditures are given in (OECD, 2015 [21]).
} 
Table A.6. List of countries covered by the indicator

\begin{tabular}{|c|c|}
\hline Australia & Turkey \\
\hline Austria & United States \\
\hline Belgium & South Africa \\
\hline Brazil & Algeria \\
\hline Canada & Angola \\
\hline Switzerland & Argentina \\
\hline Chile & Azerbaijan \\
\hline China & Bahrain \\
\hline Czech Republic & Bangladesh \\
\hline Germany & Bolivia \\
\hline Denmark & Brunei Darussalam \\
\hline Spain & Colombia \\
\hline Estonia & Ecuador \\
\hline Finland & Egypt \\
\hline France & El Salvador \\
\hline United Kingdom & Gabon \\
\hline Greece & Ghana \\
\hline Hungary & Iraq \\
\hline Indonesia & Islamic Republic of Iran \\
\hline India & Kazakhstan \\
\hline Ireland & Kuwait \\
\hline Iceland & Libya \\
\hline Israel & Malaysia \\
\hline Italy & Nigeria \\
\hline Japan & Oman \\
\hline Korea & Pakistan \\
\hline Luxembourg & Qatar \\
\hline Latvia & Saudi Arabia \\
\hline Mexico & Sri Lanka \\
\hline Netherlands & Chinese Taipei \\
\hline Norway & Thailand \\
\hline New Zealand & Trinidad and Tobago \\
\hline Poland & Turkmenistan \\
\hline Portugal & Ukraine \\
\hline Russian Federation & United Arab Emirates \\
\hline Slovak Republic & Uzbekistan \\
\hline Slovenia & Venezuela \\
\hline Sweden & Viet Nam \\
\hline
\end{tabular}

Enabling policy and regulatory environment for renewable energy.

First, for the set of countries covered by both the Inventory and the IEA, the potential overlapping individual measures were identified and their corresponding amounts were summed up to give an equivalent of a price-gap estimate. The latter was then compared to the IEA estimates.$^{54}$ In theory, OECD estimates that result in a low domestic price should match the IEA price-gap estimates. In practice, however, these can differ for several reasons. First, as OECD estimates are derived from individual policies, it could be that some measures that affect domestic fuel prices have not been included in the Inventory.

54 This set of countries is comprised of Argentina, China, Colombia, India, Indonesia, Korea, Mexico, and the Russian Federation. 
Second, measures identified as overlapping do not always affect domestic prices, or less than expected. For instance, exemptions on value-added taxes (VAT) in the Inventory are identified as potentially overlapping. However, VAT exemptions for taxi drivers, might not result in lower end-user prices for gasoline in the road sector and therefore do not match with a price-gap approach. Lastly, given that OECD estimates are based mostly on figures released on a fiscal-year basis, reporting of transfers (e.g. refunds for qualifying fuel consumption) could be delayed. The presence of reporting or time lags for fuel price passthrough could partially explain the divergence in the numbers.

After comparing the total amount of the overlapping measures from the Inventory with the total IEA estimates over five years, ${ }^{55}$ the larger of the two numbers is retained. A shortcoming of this rule-of-thumb is its inability to deal with the cross-subsidies from producers to consumers that are not publically funded and that are included in the IEA estimates but not the OECD ones, which cover the government support only. Should IEA estimates prevail as the larger of the two, then the possibility of counting these measures as consumer support could result in potential overestimation of government support. A consolidated Total Support Estimate (TSE) is derived through this approach.

\section{A5. Enabling policy and regulatory environment for renewable energy}

\section{Definition}

This indicator is the renewable energy pillar of the Regulatory Indicators for Sustainable Energy (RISE) developed by the World Bank. ${ }^{56},{ }^{57}$

The indicator on enabling policy and regulatory environment for renewable energy reports scores between 0 and 100 - where 100 implies the best performance - that capture the extent to which countries' policy and regulatory environment encourages renewable energy production and consumption, in 111 countries $^{58}$ in 2015.The variables included in the indicator's dataset are the following:

- Country name.

- ISO Code of the country.

- Year in which the supportive policies were recorded (2015).

- Legal framework for renewable energy: Score between 0 and 100 measuring the quality of the legal framework for renewable energy.

- Planning for renewable energy expansion: Score between 0 and 100 measuring the ambition of the planning for renewable energy expansion.

- Incentives and regulatory support for renewable energy: Score between 0 and 100 measuring the quality of incentives and regulatory support for renewable energy.

55 Summing up the estimates over five years minimises the risk of double counting by smoothing out budgetary reporting lags and time lags related to fuel price pass-through. Measurement errors can also be reduced since data are often revised and improved retroactively.

56 The definition of renewable energy covered by this indicator refers to power generation by biomass, solar, wind, hydropower, marine, and geothermal technologies.

57 http://rise.worldbank.org/.

58 See full list of countries below. 
- Attributes of financial and regulatory incentives: Score between 0 and 100 measuring the quality of attributes of financial and regulatory incentives.

- Network connection and pricing: Score between 0 and 100 measuring the quality of network connection and the adequacy of pricing.

- Counterparty risk of the energy firms: Score between 0 and 100 measuring the quality of the counterparty risk of the energy firms.

- Carbon pricing and monitoring: Score between 0 and 100 reporting on the stringency of carbon pricing and the quality of monitoring.

- Overall score: Synthetic Score between 0 and 100 measuring the quality of the legal and regulatory support to renewable energy. It is computed as the average of all other sub-indexes.

\section{Sources, concept, interpretations and limitations}

The indicator on support for renewable energy is the renewable energy pillar of the Regulatory Indicators for Sustainable Energy (RISE) developed by the World Bank. RISE identifies policies and regulations that provide support for sustainable energy, helping countries to progress towards national and global objectives related to climate change and sustainable development. RISE is divided into three pillars that cover the following policy areas: energy access, energy efficiency, as well as renewable energy.

The indicator on support for renewable energy is entirely based on the renewable energy pillar of RISE, which derives indexes that measure the quality of the following policy areas (Figure A.3):

- Legal framework for renewable energy: Measures the strength of the primary legislation for renewable generation and its business-friendliness.

- Planning for renewable energy expansion: Measures the ambition of renewable expansion through official targets and associated resources and through the availability of information that is necessary for developers (e.g. geological data to optimize the location of renewable energy plants that rely on natural resources like exposition to sunlight and wind).

- Incentives and regulatory support: Captures the government measures to improve the financial returns or reduce the risks of private projects through financial (e.g. feed-in tariffs) and fiscal (e.g. capital subsidies) incentives.

- Attributes of financial and regulatory incentives: Measures how incentives are clear, predictable, and financially sustainable through, for instance, the existence of defined market entry mechanisms for private renewable energy projects or clear rules on price level modification ensuring income predictability for power generation developers.

- Network connection and use: Measures the quality of network connection and the adequacy of pricing.

- Counterparty risk of the energy firms: Assesses risks and uncertainties related to investments in renewable energy markets through measures that enhance transparency on the creditworthiness of utilities buying power to private generators or through government guarantees of payments to generators. 
- Carbon pricing and monitoring: Measures the stringency of carbon pricing and the quality of the verification system for greenhouse gas emissions.

To obtain a metric on the support for renewable energy, RISE uses a scoreboard derived from a questionnaire completed by energy experts from 111 countries. ${ }^{59}$ From their answers, each of the subareas was scored on a scale between 0 and 100, where 100 implies the best performance. The total score was then calculated as a simple average. As a result, as the method assigns equal weight to each sub-area it does not account for the relative importance of different policy decisions. This simplification is necessary as the relative importance of specific policy areas inevitably varies by country, depending on factors such as the size and maturity of the market for renewable energy, as well as external political and economic risks.

Figure A.3. Renewable energy pillar

\begin{tabular}{|c|c|c|}
\hline \multicolumn{3}{|c|}{ Policies and Regulations } \\
\hline $\begin{array}{l}\text { Legal framework for renewable energy } \\
\text { - Primary legislation } \\
\text { - Legal private ownership of generation } \\
\text { Planning for renewable energy expansion } \\
\text { - Renewable energy targets and plans } \\
\text { - Renewable energy in generation planning } \\
\text { - Renewable energy in transmission planning } \\
\text { - Resource data and siting }\end{array}$ & $\begin{array}{l}\text { - Incentives \& regulatory support } \\
\text { - Gridancial and regulatory incentives } \\
\text { Attributes of financial and regulatory incentives } \\
\text { - Predictabillity and efficiency (policy-neutral) } \\
\text { - Predictability and efficiency (policy-specific) } \\
\text { - Long-term sustainability } \\
\text { - Network connection and use } \\
\text { - Nonnection cost allocation } \\
\text { - Renewable usage and pricing } \\
\text { Rrid integration }\end{array}$ & $\begin{array}{l}\text { Counterparty risk } \\
\text { - Payment risk reduction } \\
\text { - Utility creditworthiness } \\
\text { - Utility transparency and monitoring } \\
\text { Carbon pricing and monitoring } \\
\text { - Carbon pricing mechanism } \\
\text { - Monitoring, reporting and verification } \\
\text { (MRV) system }\end{array}$ \\
\hline
\end{tabular}

Source: Banerjee et al. (2017).

The latest edition of RISE covers 111 countries, accounting for $96 \%$ of world's population and $91 \%$ of global energy consumption, and covering $97 \%$ of people without electricity access. As the analysis is conducted on a country-level basis, many of the underlying questions relate to national policies and regulations. However, some policies are set at the state or even municipal level for which RISE has adopted the methodology developed by the World Bank's Doing Business Report, with data and scores reflecting the perspective of the largest business city in each country.

The 2017 edition of RISE provides complete information to the end of 2015 and will be updated every two years. This allows for year-to-year evaluation and provides an overview on the evolution of legal and regulatory supports to renewable energy. New editions could adapt to new technologies and policy approaches.

One caveat is that RISE does not measure the level (i.e. the price) of the different incentives for renewable energy production. For instance, it captures whether schemes exist to support

59 It took countries about three months to complete the questionnaire and return before the cut-off date of 31 December 2015. Each answer needed to be supported by evidence, either through an official public document or through interviews with at least two country energy experts. Each answer to the questionnaire and its supporting documentation was reviewed and validated by the RISE team, the World Bank country teams, and checked for consistency by internal and external groups (Banerjee et al., 2017). 
renewable energy per unit of electricity generated (e.g. feed-in tariff or production tax credits) but does not measure their price. The latter is, however, an important attribute of any renewable energy support programme.

Table A.7. List of countries covered by the indicator

\begin{tabular}{|c|c|c|}
\hline Afghanistan & Ghana & Peru \\
\hline Algeria & Greece & Philippines \\
\hline Angola & Guatemala & Poland \\
\hline Argentina & Guinea & Qatar \\
\hline Armenia & Haiti & Romania \\
\hline Australia & Honduras & Russian Federation \\
\hline Austria & India & Rwanda \\
\hline Bahrain & Indonesia & Saudi Arabia \\
\hline Bangladesh & Iran, Islamic Rep. & Senegal \\
\hline Belarus & Italy & Sierra Leone \\
\hline Belgium & Japan & Solomon Islands \\
\hline Benin & Jordan & Somalia \\
\hline Bolivia & Kazakhstan & South Africa \\
\hline Brazil & Kenya & South Sudan \\
\hline Burkina Faso & Korea, & Spain \\
\hline Burundi & Kuwait & Sri Lanka \\
\hline Cambodia & Kyrgyz Republic & Sudan \\
\hline Cameroon & Lao PDR & Sweden \\
\hline Canada & Lebanon & Switzerland \\
\hline Central African Republic & Liberia & Tajikistan \\
\hline Chad & Madagascar & Tanzania \\
\hline Chile & Malawi & Thailand \\
\hline China & Malaysia & Togo \\
\hline Colombia & Maldives & Tunisia \\
\hline Congo, Dem. Rep. & Mali & Turkey \\
\hline Congo, Rep. & Mauritania & Uganda \\
\hline Côte d'Ivoire & Mexico & Ukraine \\
\hline Czech Republic & Mongolia & United Arab Emirates \\
\hline Denmark & Morocco & United Kingdom \\
\hline Dominican Republic & Mozambique & United States \\
\hline Ecuador & Myanmar & Uzbekistan \\
\hline Egypt, Arab Rep. & Nepal & Vanuatu \\
\hline Eritrea & Netherlands & Venezuela, RB \\
\hline Ethiopia & Nicaragua & Viet Nam \\
\hline Finland & Niger & Yemen, Rep. \\
\hline France & Nigeria & Zambia \\
\hline Germany & Pakistan & Zimbabwe \\
\hline
\end{tabular}

Source: http://rise.worldbank.org/

\section{A7. The volume of trade in waste and scrap}

\section{Definition}

The indicator reports the amount of exports and imports of waste and scrap as defined in Kellenberg (2012) in current USD and in kilograms for all countries between 2003 and 2016. The variables included in the indicator's dataset are the following: 
- Country name.

- ISO code of the country considered.

- Year the data on trade flows were recorded.

- HS code: The code in the Harmonized System (HS) identifying the traded good. Codes for years 2002-2008 are reported in the H2 version of the HS, codes for years 2009-2011 are reported in the H3 version of the HS, codes for years 20122016 are reported in the H4 version of the HS.

- Categories: Section of the HS code that groups traded goods by type of industry.

- Exports value: Value of exports from the considered country in current USD.

- Exports weight: Weight of exports from the considered country in kilograms.

- Imports value: Value of imports in the considered country in current USD.

- Imports weight: Weight of imports in the considered country in kilograms.

\section{Concepts, interpretation and limitations}

From a trade and environment perspective, the interpretation of an indicator on trade in waste and scrap is not straightforward. As explained above, the effect of trade in waste and scrap on the environment depends on the destination's environmental policy stringency for waste management and the type of infrastructures available to implement the associated programs. If the bulk of waste and scrap trade flows go to countries with high standards waste management facilities, it could be deemed that trade plays a positive role for the environment. On the contrary, if destinations have on average lower environmental standards for waste management (with non-compliant waste-recovery facilities, landfills, or even open dumping), trade in waste and scrap would most probably have an adverse effect on the environment.

Constructing time series that measure the evolution of trade volume in waste and scrap is therefore not sufficient to understand the very nature of the trade flows. One would also need an indicator that captures the environmental policy stringency for waste management and the quality of infrastructures available to implement the associated programs in each country. Such an indicator is however not available. The main reason is that no international database on waste management standards exists. A time series of trade volume in waste and scrap is therefore only a starting point.

Perhaps the most sensible approach is to turn to the list of 62 Harmonized System (HS) ${ }^{60}$ codes provided by Kellenberg (2012) where there are specific classifications limited to waste, scrap or both. They cover both hazardous and non-hazardous waste and scrap although these two categories cannot be distinguished based on the current data available. ${ }^{61}$

60 The Harmonized System (HS) is the international nomenclature for classification of products.

61 The Basel Convention has its own classification of hazardous waste based on the characteristics of the material (e.g. toxic or poisonous) but not on the products themselves like the HS nomenclature (e.g. ferrous waste or clinical waste). Therefore, there is currently no straightforward correspondence between trade flows recorded in the HS and those in the database of the Basel Convention. As a result, it is impossible to distinguish between hazardous and non-hazardous trade flows in the HS. In addition, data on cross-borders movements of hazardous waste available from the Basel Convention present many drawbacks and are hardly exploitable. First, the data are self-reported, which can be 
The list of HS codes with their full definition can be found in Appendix. In addition, waste and scrap are also categorised by their HS sections, which group traded goods by type of industry. ${ }^{62}$

Nevertheless, this is an imperfect approach because the HS strictly focusses on the nature and composition and the physical properties of a good whereas a product should be considered as waste when there is the intention to discard or to recycle it. For example, the Basel Convention has a code for pneumatic tyres that are destined for recycling. The HS makes no distinction between tyres for reuse, recycling or disposal. Therefore, these are not categorised as waste but rather as retreated or used tyres.

\section{Sources, measurability and data quality}

The source data to calculate the volume of trade in waste and scrap is the Base pour l'analyse du commerce international (BACI) International Trade database. ${ }^{63}$ Data on traded volumes are available from UN COMTRADE database, the repository of official international trade statistics. However, COMTRADE database is contaminated by missing values (i.e. values not reported by countries) and by discrepancies (i.e. when the exporter and the importer report two different numbers for the same trade flow).

The BACI International Trade database provides a single consistent figure for each bilateral flow that corrects these discrepancies in mirror flows. The reconciliation methodology relies on two steps. ${ }^{64}$ First, removing transport costs from reported imports since the latter are generally reported CIF (cost, insurance and freight) as opposed to export values, which are reported FOB (free on board). Second, evaluating the accuracy of each country's reports and using it as a weight to average reported mirror flows, now cleaned from CIF rates. ${ }^{65}$

For these reasons, the BACI database is more reliable than the raw data observed in the COMTRADE database and is therefore used to construct this indicator. Therefore, it should also be noted that numbers from this indicator can significantly differ from official data from national customs agencies, which are the main sources of COMTRADE database.

problematic as large volumes of waste may not be reported (Kellenberg, 2012). Second, self-reporting is mandatory only for hazardous waste, which may ignore an important part of the issue. Nonhazardous waste (as defined by the Basel Convention) still must be handled and disposed of in an environmentally safe manner. For example, plastics or plastic-coated copper wire would not be classified as hazardous waste, but "improper" incineration can release toxic and harmful fumes. Third, the United States (the world's largest exporter of waste) is absent from the countries covered in the database because it did not ratify the Convention.

62 For definitions of sections in the Harmonized System, see https://unstats.un.org/unsd/tradekb/Knowledgebase/50043/HS-2002-Classification-by-Section.

63 Data from BACI International Trade database can be downloaded from http://www.cepii.fr/CEPII/en/bdd_modele/presentation.asp?id=1.

64 For a complete explanation of the methodology, see Gaulier and Zignago (2010).

65 The reconciled value $(R V)$ of exporter $V_{i}$ and importer $V_{j}$ is defined as $R V=\omega * V_{i}+(1-\omega) *$ $V_{j}$, where $\omega$ is a measure of the relative quality of the reports of country $i$ compared to the reports of country $j$. 


\section{Issues with the updates of the Harmonized System}

The Harmonized System is updated every five years. Each update may modify, merge, divide existing HS codes or create new ones. The UN COMTRADE website provides details on the relationships between codes across different HS versions. These relationships take four different forms:

- $1: 1$ : The code in an updated HS version remains the same as in the previous HS version;

- 1:numerous : The code in an updated HS version is a merge of several codes from the previous HS version.

- numerous: 1 : Several codes in an updated HS version are created from one code in the previous HS version.

- numerous:numerous : Several codes in an updated HS version are created from both a split and merge of several codes in the previous version.

From such relationships - also called correlations - each code can be linked to all related codes in another HS version, previous or subsequent. ${ }^{66}$ The following figure provides illustrative examples of these relationships.

Figure A.4. Relationships between classification codes in different HS versions

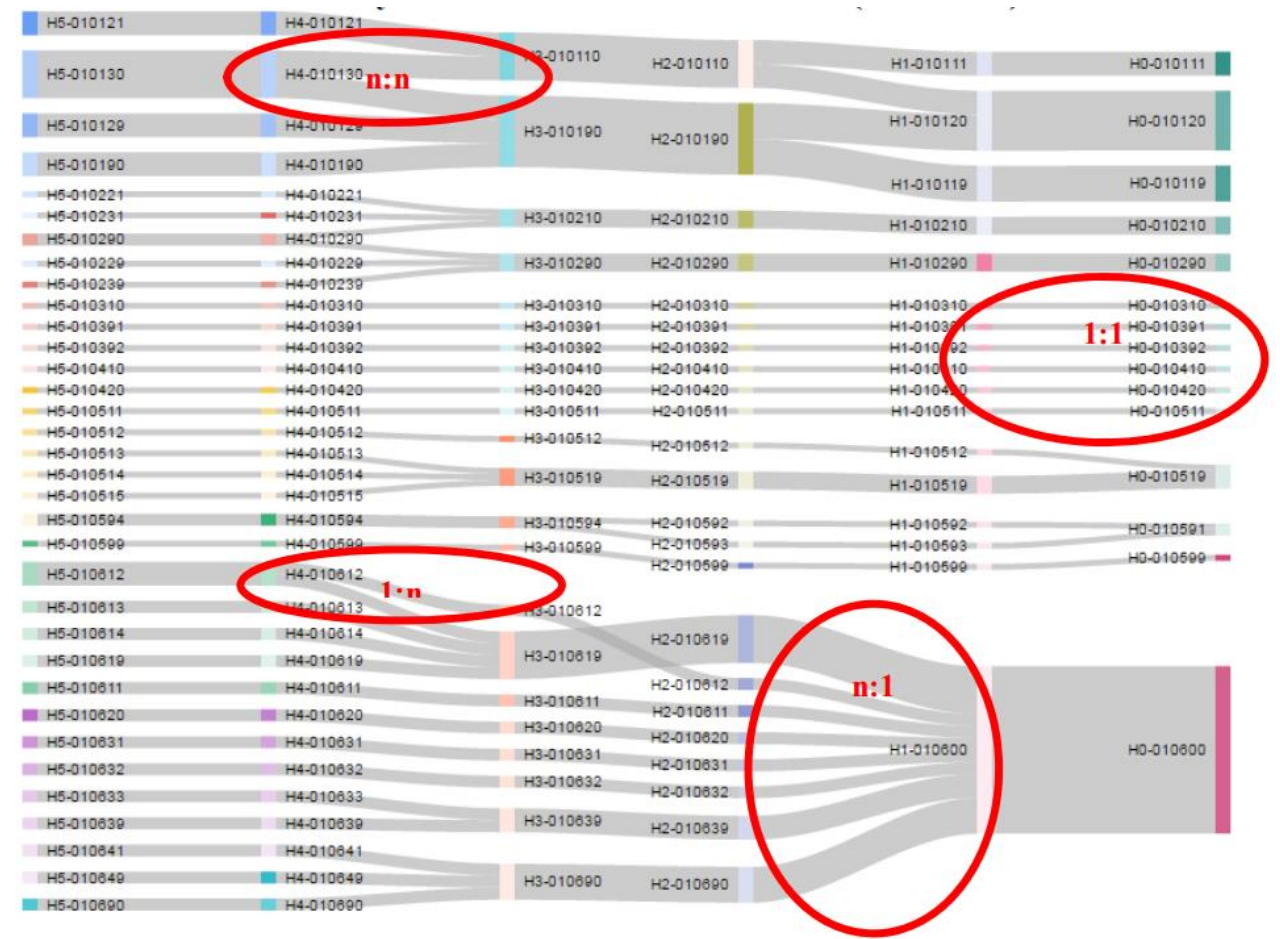

Source: UN COMTRADE.

66 Correlation tables can be found at https://unstats.un.org/unsd/trade/classifications/correspondencetables.asp. 


\section{Finding a correspondent code in another HS version}

The list of waste and scrap was defined in the HS version of 2002. To create a time series covering the 2002-2017 period over these categories of goods, it is necessary, for each code in the list, to find a correspondent code in HS versions of 2007, 2012 and $2017 .{ }^{67}$

To establish such correspondences, the UN Statistics Division (UNSD) approach is to convert a code of a given version into one and only one code of another HS version. ${ }^{68}$ This code is selected among those that correlate (i.e. those identified through the relationships defined above). Therefore, it is important to note here that correspondences provide the closest classification code in another HS version, but not (necessarily) an identical one. As a result, observed variations in the volume of trade in years of an HS update for some categories of goods can partly be due to changes in their definition in the Harmonized System.

UN COMTRADE provides correspondence tables for a given HS version to earlier ones. The methodology used to construct these tables can then be replicated to establish correspondences between the 2002 HS version and subsequent versions (2007, 2012 and 2017).

In more details, this methodology works as follows. From the 2002 HS version to subsequent HS versions, all codes with a 1:1 or a 1:n relationship have a straightforward correspondence since there is only one available code.

For all n:1 and n:n relationships - which involve many correlated codes in a subsequent HS version - the selection is made using the "retained code" rule. The retained code rule assigns the HS 2002 code to the code itself if one of the correlated codes is identical. The retained code rule is based on the general World Custom Organization (WCO) practice that maintains the existing code only if there has been no substantial change of scope (United Nations Statistic Division, 2017).

Otherwise, if no correlated code is identical, it is manually decided which HS codes are to correspond with the original code in the list. HS codes (in the 2007, 2012 and 2017 HS versions) were analysed to determine whether they still can be considered "waste or scrap". This is done looking at the name and description of those new codes in the COMTRADE database.

To sum up, changes made to the list for correspondences in subsequent HS versions were as follows:

- From HS 2002 to HS 2007. All HS 2002 codes from the original list of waste goods have a 1:1 or a 1:n relationship with HS 2007 codes. Therefore, correspondences are straightforwardly assigned to the single available code.

- From HS 2002 to HS 2012. All HS 2002 codes from the original list of waste goods have a 1:1 or a 1:n relationship with HS 2012 codes except 440130 ("Wood;

67 While correspondences between HS versions of 2002 and 2017 already exist, trade data is not yet available. The next version of the indicator will provide figures for the year 2017 using the correspondences defined in this section.

68 An alternative is to divide the trade value of a code into his correlates according to their trade share. However, this approach implies heroic assumptions if the correlated code is in relationships with other codes in the current HS version. 
sawdust, waste and scrap), which separates into HS 2012 codes 440131 and 440139. Code 440131 represents approximately $70 \%$ of the total trade of categories 440131 and 440139. Therefore, following UN's methodology, whereby the HS 2002 code is assigned to the code that has the largest trade share ${ }^{69}$, the HS 2012 code 440131 is retained as the correspondence of the HS 2002 code 440130.

- From HS 2002 to HS 2017. All HS 2002 codes from the original list of waste goods that have a n:1 or a n:n relationship can be assigned through the "retained code" rule in the HS 2017 version except code 440130, which as before separates into 440131 and 440139. Again, the HS 2017 code 440131 is retained as the correspondence of the HS 2002 code 440130.

Table A.8. Description of HS codes covered by the indicator on the volume of trade in waste and scrap

\begin{tabular}{|c|c|c|c|}
\hline $\begin{array}{l}\text { HS } \\
\text { code }\end{array}$ & Classification & Description & Categories \\
\hline 251720 & $\mathrm{H} 2$ & $\begin{array}{l}\text { Macadam of slag, dross or similar industrial waste; whether or not incorporating } \\
\text { the materials in item no. } 2517.10\end{array}$ & Minerals \\
\hline 252530 & $\mathrm{H} 2$ & Mica; waste & Minerals \\
\hline 261900 & $\mathrm{H} 2$ & $\begin{array}{l}\text { Slag, dross; (other than granulated slag), scalings and other waste from the } \\
\text { manufacture of iron or steel }\end{array}$ & Minerals \\
\hline 262110 & $\mathrm{H} 2$ & Slag and ash; ash and residues from the incineration of municipal waste & Minerals \\
\hline 271091 & $\mathrm{H} 2$ & $\begin{array}{l}\text { Waste Oils; of petroleum or obtained from bituminous minerals, not crude; and } \\
\text { preparations n.e.c., weight } 70 \% \text { or preparations of the same, containing } \\
\text { polychlorinated biphenyls (PCBs), polychorinated terphenyls (PCTs) or } \\
\text { polybrominated biphenyls (PBBs) }\end{array}$ & Minerals \\
\hline 271099 & $\mathrm{H} 2$ & $\begin{array}{l}\text { Waste Oils;of petroleum or obtained from bituminous minerals, not crude;and } \\
\text { preparations n.e.c., weight } 70 \% \text { or preparations of the same, not containing } \\
\text { polychlorinated biphenyls (PCBs), polychorinated terphenyls (PCTs) or } \\
\text { polybrominated biphenyls (PBBs) }\end{array}$ & Minerals \\
\hline 300680 & $\mathrm{H} 2$ & Pharmaceutical goods; waste pharmaceuticals & Chemicals \\
\hline 382510 & $\mathrm{H} 2$ & $\begin{array}{l}\text { Residual products of the chemical or allied industries, not elsewhere specified or } \\
\text { included; municipal waste }\end{array}$ & Chemicals \\
\hline 382530 & $\mathrm{H} 2$ & $\begin{array}{l}\text { Residual products of the chemical or allied industries, not elsewhere specified or } \\
\text { included; clinical waste }\end{array}$ & Chemicals \\
\hline 382541 & $\mathrm{H} 2$ & $\begin{array}{l}\text { Residual products of the chemical or allied industries, not elsewhere specified or } \\
\text { included; halogenated waste organic solvents }\end{array}$ & Chemicals \\
\hline 382549 & $\mathrm{H} 2$ & $\begin{array}{l}\text { Residual products of the chemical or allied industries, not elsewhere specified or } \\
\text { included; waste organic solvents, other than halogenated }\end{array}$ & Chemicals \\
\hline 382550 & $\mathrm{H} 2$ & $\begin{array}{l}\text { Residual products of chemical or allied industries, not elsewhere specified or } \\
\text { included; wastes of metal pickling liquors, hydraulic fluids, brake fluids and anti- } \\
\text { freeze fluids }\end{array}$ & Chemicals \\
\hline 382561 & $\mathrm{H} 2$ & $\begin{array}{l}\text { Residual products of the chemical or allied industries, not elsewhere specified or } \\
\text { included; (other than sewage sludge, municipal waste or waste covered in } \\
\text { 27.10); other wastes n.e.c. in 3825; those mainly containing organic constituents }\end{array}$ & Chemicals \\
\hline 382569 & $\mathrm{H} 2$ & $\begin{array}{l}\text { Residual products of the chemical or allied industries, not elsewhere specified or } \\
\text { included; (other than sewage sludge, municipal waste or waste covered by } \\
27.10 \text { ); other wastes n.e.c. in } 3825 \text {; except those mainly containing organic } \\
\text { constituents }\end{array}$ & Chemicals \\
\hline 382590 & $\mathrm{H} 2$ & $\begin{array}{l}\text { Residual products of the chemical or allied industries, not elsewhere specified or } \\
\text { included; n.e.c. in } 3825 \text { or } 27.10\end{array}$ & Chemicals \\
\hline 391510 & $\mathrm{H} 2$ & Ethylene polymers; waste, parings and scrap & Plastics \\
\hline 391520 & $\mathrm{H} 2$ & Styrene polymers; waste, parings and scrap & Plastics \\
\hline 391530 & $\mathrm{H} 2$ & Vinyl chloride polymers; waste, parings and scrap & Plastics \\
\hline
\end{tabular}

69 See Rule 6 (p.5) of United Nations Statistics Division, 2017. 


\begin{tabular}{|c|c|c|c|}
\hline 391590 & $\mathrm{H} 2$ & Plastics n.e.s. in heading no. 3915 ; waste, parings and scrap & Plastics \\
\hline 400400 & $\mathrm{H} 2$ & $\begin{array}{l}\text { Rubber; waste, parings and scrap of rubber (other than hard rubber) and } \\
\text { powders and granules obtained therefrom }\end{array}$ & Plastics \\
\hline 411520 & $\mathrm{H} 2$ & $\begin{array}{l}\text { Leather; parings and other waste, of leather or composition leather; not suitable } \\
\text { for the manufacture of leather articles; leather dust, powder and flour }\end{array}$ & Other \\
\hline 440130 & $\mathrm{H} 2$ & $\begin{array}{l}\text { Wood; sawdust, waste and scrap, whether or not agglomerated in logs, } \\
\text { briquettes, pellets or similar forms }\end{array}$ & Papers \\
\hline 450190 & $\mathrm{H} 2$ & Cork; waste cork, crushed, granulated or ground cork & Papers \\
\hline 470710 & $\mathrm{H} 2$ & $\begin{array}{l}\text { Paper or paperboard; waste and scrap, of unbleached kraft paper or paperboard } \\
\text { or corrugated paper or paperboard }\end{array}$ & Papers \\
\hline 470720 & $\mathrm{H} 2$ & $\begin{array}{l}\text { Paper or paperboard; waste and scrap, paper or paperboard made mainly of } \\
\text { bleached chemical pulp, not coloured in the mass }\end{array}$ & Papers \\
\hline 470730 & $\mathrm{H} 2$ & $\begin{array}{l}\text { Paper or paperboard; waste and scrap, paper or paperboard made mainly of } \\
\text { mechanical pulp (eg newspapers, journals and similar printed matter) }\end{array}$ & Papers \\
\hline 470790 & $\mathrm{H} 2$ & $\begin{array}{l}\text { Paper or paperboard; waste and scrap, of paper or paperboard n.e.s. in heading } \\
\text { no. } 4707 \text { and of unsorted waste and scrap }\end{array}$ & Papers \\
\hline 500310 & $\mathrm{H} 2$ & $\begin{array}{l}\text { Silk; waste, not carded or combed (including cocoons unsuitable for reeling, } \\
\text { yarn waste and garnetted stock) }\end{array}$ & Textile \\
\hline 500390 & $\mathrm{H} 2$ & $\begin{array}{l}\text { Silk; waste, carded or combed (including cocoons unsuitable for reeling, yarn } \\
\text { waste and garnetted stock) }\end{array}$ & Textile \\
\hline 510320 & $\mathrm{H} 2$ & $\begin{array}{l}\text { Wool and hair; waste of wool or of fine animal hair, including yarn waste, but } \\
\text { excluding garnetted stock and noils of wool or of fine animal hair }\end{array}$ & Textile \\
\hline 510330 & $\mathrm{H} 2$ & $\begin{array}{l}\text { Wool and hair; waste of coarse animal hair, including yarn waste, but excluding } \\
\text { garnetted stock }\end{array}$ & Textile \\
\hline 520210 & $\mathrm{H} 2$ & Cotton; yarn waste (including thread waste) & Textile \\
\hline 520299 & $\mathrm{H} 2$ & Cotton; waste other than garnetted stock and yarn (including thread) waste & Textile \\
\hline 550510 & $\mathrm{H} 2$ & $\begin{array}{l}\text { Fibres; waste (including noils, yarn waste and garnetted stock), of synthetic } \\
\text { fibres }\end{array}$ & Textile \\
\hline 550520 & $\mathrm{H} 2$ & Fibres; waste (including noils, yarn waste and garnetted stock), of artificial fibres & Textile \\
\hline 711291 & $\mathrm{H} 2$ & $\begin{array}{l}\text { Waste and scrap of precious metals; of gold, including metal clad with gold but } \\
\text { excluding sweepings containing other precious metals }\end{array}$ & Metals \\
\hline 711299 & $\mathrm{H} 2$ & $\begin{array}{l}\text { Waste and scrap of precious metals; waste and scrap of precious metals } \\
\text { including metal clad with precious metals, other than that of gold and platinum } \\
\text { and excluding ash which contains precious metal or precious metal compounds }\end{array}$ & Metals \\
\hline 720410 & $\mathrm{H} 2$ & Ferrous waste and scrap; of cast iron & Metals \\
\hline 720421 & $\mathrm{H} 2$ & Ferrous waste and scrap; of stainless steel & Metals \\
\hline 720429 & $\mathrm{H} 2$ & Ferrous waste and scrap; of alloy steel (excluding stainless) & Metals \\
\hline 720430 & $\mathrm{H} 2$ & Ferrous waste and scrap; of tinned iron or steel & Metals \\
\hline 720441 & $\mathrm{H} 2$ & $\begin{array}{l}\text { Ferrous waste and scrap; turnings, shavings, chips, milling waste, sawdust, } \\
\text { fillings, trimmings and stampings, whether or not in bundles }\end{array}$ & Metals \\
\hline 720449 & $\mathrm{H} 2$ & Ferrous waste and scrap; n.e.s. in heading no. 7204 & Metals \\
\hline 740400 & $\mathrm{H} 2$ & Copper; waste and scrap & Metals \\
\hline 750300 & $\mathrm{H} 2$ & Nickel; waste and scrap & Metals \\
\hline 760200 & $\mathrm{H} 2$ & Aluminium; waste and scrap & Metals \\
\hline 780200 & $\mathrm{H} 2$ & Lead; waste and scrap & Metals \\
\hline 790200 & $\mathrm{H} 2$ & Zinc; waste and scrap & Metals \\
\hline 800200 & $\mathrm{H} 2$ & Tin; waste and scrap & Metals \\
\hline 810197 & $\mathrm{H} 2$ & Tungsten (wolfram); waste and scrap & Metals \\
\hline 810297 & $\mathrm{H} 2$ & Molybdenum; waste and scrap & Metals \\
\hline 810330 & $\mathrm{H} 2$ & Tantalum; waste and scrap & Metals \\
\hline 810420 & $\mathrm{H} 2$ & Magnesium; waste and scrap & Metals \\
\hline 810530 & $\mathrm{H} 2$ & Cobalt; waste and scrap & Metals \\
\hline 810600 & $\mathrm{H} 2$ & Bismuth; articles thereof, including waste and scrap & Metals \\
\hline 810730 & $\mathrm{H} 2$ & Cadmium; waste and scrap & Metals \\
\hline 810830 & $\mathrm{H} 2$ & Titanium; waste and scrap & Metals \\
\hline 810930 & $\mathrm{H} 2$ & Zirconium; waste and scrap & Metals \\
\hline
\end{tabular}




\begin{tabular}{|c|c|c|c|}
\hline 811020 & $\mathrm{H} 2$ & Antimony; waste and scrap & Metals \\
\hline 811213 & $\mathrm{H} 2$ & Beryllium; waste and scrap & Metals \\
\hline 811222 & $\mathrm{H} 2$ & Chromium; waste and scrap & Metals \\
\hline 854810 & $\mathrm{H} 2$ & $\begin{array}{l}\text { Waste and scrap of primary cells, primary batteries and electric accumulators; } \\
\text { spent primary cells, spent primary batteries and spent electric accumulators }\end{array}$ & Other \\
\hline
\end{tabular}

Note: All codes defined in the version $\mathrm{H} 2$ of the Harmonized System.

Source: Kellenberg (2012).

Table A.9. Correspondence of the waste and scrap list in different HS versions

\begin{tabular}{|c|c|c|c|c|c|}
\hline HS 1992 (H0) & HS 1996 (H1) & HS 2002 (H2) & HS 2007 (H3) & HS 2012 (H4) & HS 2017 (H5) \\
\hline 440130 & 440130 & 440130 & 440130 & 440131 & 440131 \\
\hline 850730 & 854810 & 854810 & 854810 & 854810 & 854810 \\
\hline 251720 & 251720 & 251720 & 251720 & 251720 & 251720 \\
\hline 252530 & 252530 & 252530 & 252530 & 252530 & 252530 \\
\hline 261900 & 261900 & 261900 & 261900 & 261900 & 261900 \\
\hline 262100 & 262100 & 262110 & 262110 & 262110 & 262110 \\
\hline 271000 & 271000 & 271091 & 271091 & 271091 & 271091 \\
\hline 271000 & 271000 & 271099 & 271099 & 271099 & 271099 \\
\hline 300490 & 300490 & 300680 & 300692 & 300692 & 300692 \\
\hline 382390 & 382490 & 382510 & 382510 & 382510 & 382510 \\
\hline 901839 & 901839 & 382530 & 382530 & 382530 & 382530 \\
\hline 382390 & 382490 & 382541 & 382541 & 382541 & 382541 \\
\hline 382390 & 382490 & 382549 & 382549 & 382549 & 382549 \\
\hline 382390 & 382490 & 382550 & 382550 & 382550 & 382550 \\
\hline 382390 & 382490 & 382561 & 382561 & 382561 & 382561 \\
\hline 382390 & 382490 & 382569 & 382569 & 382569 & 382569 \\
\hline 382390 & 382490 & 382590 & 382590 & 382590 & 382590 \\
\hline 391510 & 391510 & 391510 & 391510 & 391510 & 391510 \\
\hline 391520 & 391520 & 391520 & 391520 & 391520 & 391520 \\
\hline 391530 & 391530 & 391530 & 391530 & 391530 & 391530 \\
\hline 391590 & 391590 & 391590 & 391590 & 391590 & 391590 \\
\hline 400400 & 400400 & 400400 & 400400 & 400400 & 400400 \\
\hline 411000 & 411000 & 411520 & 411520 & 411520 & 411520 \\
\hline 450190 & 450190 & 450190 & 450190 & 450190 & 450190 \\
\hline 470710 & 470710 & 470710 & 470710 & 470710 & 470710 \\
\hline 470720 & 470720 & 470720 & 470720 & 470720 & 470720 \\
\hline 470730 & 470730 & 470730 & 470730 & 470730 & 470730 \\
\hline 470790 & 470790 & 470790 & 470790 & 470790 & 470790 \\
\hline 500310 & 500310 & 500310 & 500300 & 500300 & 500300 \\
\hline 500390 & 500390 & 500390 & 500300 & 500300 & 500300 \\
\hline 510320 & 510320 & 510320 & 510320 & 510320 & 510320 \\
\hline 510330 & 510330 & 510330 & 510330 & 510330 & 510330 \\
\hline 520210 & 520210 & 520210 & 520210 & 520210 & 520210 \\
\hline 520299 & 520299 & 520299 & 520299 & 520299 & 520299 \\
\hline 550510 & 550510 & 550510 & 550510 & 550510 & 550510 \\
\hline 550520 & 550520 & 550520 & 550520 & 550520 & 550520 \\
\hline 711210 & 711210 & 711291 & 711291 & 711291 & 711291 \\
\hline 711290 & 711290 & 711299 & 711299 & 711299 & 711299 \\
\hline 720410 & 720410 & 720410 & 720410 & 720410 & 720410 \\
\hline 720421 & 720421 & 720421 & 720421 & 720421 & 720421 \\
\hline 720429 & 720429 & 720429 & 720429 & 720429 & 720429 \\
\hline 720430 & 720430 & 720430 & 720430 & 720430 & 720430 \\
\hline 720441 & 720441 & 720441 & 720441 & 720441 & 720441 \\
\hline
\end{tabular}




\begin{tabular}{llllll}
\hline 720449 & 720449 & 720449 & 720449 & 720449 & 720449 \\
740400 & 740400 & 740400 & 740400 & 740400 & 740400 \\
750300 & 750300 & 750300 & 750300 & 750300 & 750300 \\
760200 & 760200 & 760200 & 760200 & 760200 & 760200 \\
780200 & 780200 & 780200 & 780200 & 780200 & 780200 \\
790200 & 790200 & 790200 & 790200 & 790200 & 790200 \\
800200 & 800200 & 800200 & 800200 & 800200 & 800200 \\
810191 & 810191 & 810197 & 810197 & 810197 & 810197 \\
810291 & 810291 & 810297 & 810297 & 810297 & 810297 \\
810310 & 810310 & 810330 & 810330 & 810330 & 810330 \\
810420 & 810420 & 810420 & 810420 & 810420 & 810420 \\
810510 & 810510 & 810530 & 810530 & 810530 & 810530 \\
810600 & 810600 & 810600 & 810600 & 810600 & 810600 \\
810710 & 810710 & 810730 & 810730 & 810730 & 810730 \\
810810 & 810810 & 810830 & 810830 & 810830 & 810830 \\
810990 & 810990 & 810930 & 810930 & 810930 & 810930 \\
811000 & 811000 & 811020 & 811020 & 811020 & 811020 \\
811211 & 811211 & 811213 & 811213 & 811213 & 811213 \\
811220 & 811220 & 811222 & 811222 & 811222 & 811222 \\
\hline
\end{tabular}

Note: The original list of codes is defined in the version $\mathrm{H} 2$ of the Harmonized System.

\section{A8. Nutrient balances of exported grains}

\section{Definition}

The indicator reports the nutrient balance of $\mathrm{N}$ and $\mathrm{P}$ - the difference between the quantity of nutrient inputs entering an agricultural system and the quantity of nutrient outputs leaving this system - for exports of nine cereal and oilseed (hence excluding pasture)as a share of the total nutrient balance for 21 countries $^{70}$ between 2006 and 2014. Grains covered by this indicator are wheat, maize, barley, sorghum, oats, rice soybeans, sunflower seed and rapeseed. The variables included in the indicator's dataset are the following:

- Country name.

- ISO code of the country.

- Year the data was recorded (year of production for the nutrient balance of production, year of export for the nutrient balance of exports).

- Nutrient balance for exported grains as a share of total nutrient balance - nitrogen: The ratio between the nitrogen balance for exported grains and the nitrogen balance for total produced grains.

- Nutrient balance for exported grains as a share of total nutrient balance-phosphorus: The ratio between the phosphorus balance for exported grains and the phosphorus balance for total produced grains.

- Share of exported grains (in volume): The ratio between the volume of exported grains and the volume of total produced grains (in tonnes).

70 See full list of countries below. 


\section{Sources, concepts, interpretation and limitations}

This indicator provides the $\mathrm{N}$ and $\mathrm{P}$ balances for exports, expressed as the share of total $\mathrm{N}$ or P balance, for 21 countries in years 2006, 2007, 2010 and 2014. Grains covered by this indicator are wheat, maize, barley, sorghum, oats, rice soybeans, sunflower seed and rapeseed.

The nutrient balance ( $\mathrm{N}$ and $\mathrm{P}$ ) for the production of a given grain is defined as the difference between the total quantity of nutrient inputs entering an agricultural system (fertilisers, livestock manure applied on lands for the covered crops, nitrogen fixated by plants and atmospheric nutrient deposit) and the quantity of nutrient outputs leaving the system (the uptake of nutrients by crops) - see Figure A.5. The estimation procedure of the nutrient balance for the given grain can be found in the next section.

Figure A.5. Main elements in the nitrogen and phosphorus balance calculations

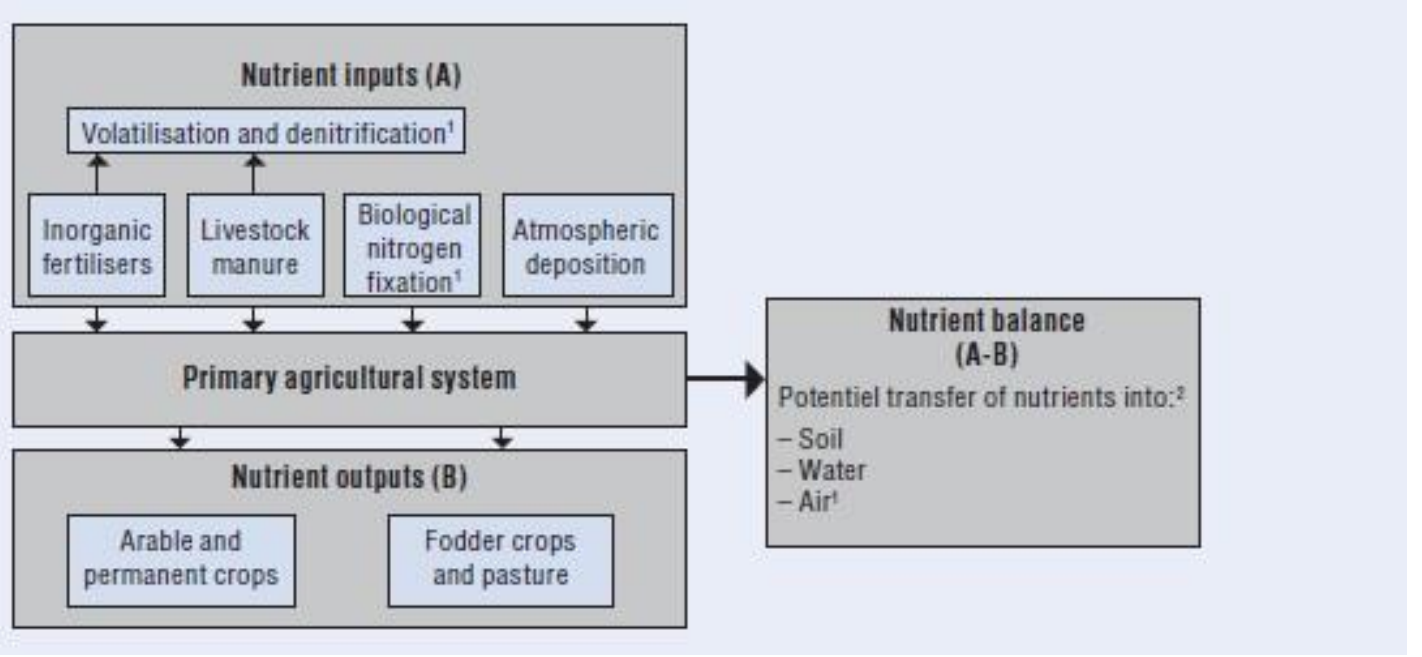

1. Note: Applies to nitrogen balance only.

2. Note: Nutrient surplus to crop/pasture requirements are transposed into the environment, potentially polluting soils, water and air, but a deficit of nutrients in soils can also occur to the detriment of soil fertility and crop productivity.

Source: Eurostat/OECD (2013), Nitrogen and Phosphorus Balance Handbook, cited in OECD (2013).

The nutrient balance for exported grains $(\mathrm{N}$ and $\mathrm{P}$ ) is calculated as the sum of the nutrient balances for the production of each grain considered weighted by the share of the production that is exported. ${ }^{71}$ That is:

\section{Nutrient balance of exported grains}

$$
=\sum_{k} \frac{\text { Volume exported }_{k}}{\text { Volume harvested }_{k}} * \text { Production nutrient balance }_{k}
$$

where grain $k$ belongs to the set of grains covered by this indicator: wheat, maize, other coarse grains (barley, sorghum and oats), rice, soybeans, and other oilseeds (sunflower seed

71 Information on exports volume come from the BACI International Trade database. 
and rapeseed). The nutrient balance for total produced grains - by which the nutrient balances for exported grains are divided - is then calculated as:

$$
\begin{aligned}
& \text { Nutrient balance of total produced grains } \\
& \qquad=\sum \text { Production nutrient balance }{ }_{k}
\end{aligned}
$$

The share of exported grains is also provided so that a simple interpretation is made possible. If the share of the nutrient balance for exported grains (out of the total nutrient balance) is larger than the share of exported grains (out of the total crop production in volume), it means that grains exported are more nutrient intensive than total production on average. For instance, if $40 \%$ of grains are exported but these grains account for $80 \%$ of the share of the total nutrient balance, it means that exported grains were disproportionately more nutrient-intensive than total production on average. In this case, one tonne of the representative exported grains basket has a twice-higher nutrient balance than one tonne of the representative total production basket.

Data sources come from the FAO, the International Fertilizer Association (IFA), the Base pour l'analyse du commerce international (BACI International Trade Database) ${ }^{72}$, and the OECD. There are several caveats, however, to take into account.

First, it is aggregated at the country level and does not capture local factors, such as agricultural land use or farm management approaches, which can significantly influence the actual environmental pressure of agriculture production.

Second, this indicator only captures environmental pressure from manure used as a nutrient input for the grains considered. ${ }^{73}$ Unmanaged manure, however, which is not captured by this indicator accounts for an important share of nutrients that enter the agricultural system and may be an important source of air, soil and water pollution as well as greenhouse gas emissions.

Third, nutrient input by manure only depends on the land area covered by the crops considered, although the application can differ from one crop to another.

Finally, this indicator relies on fixed-over-time coefficients on the nutrient content of grains, nitrogen fixation and atmospheric deposition although these factors can vary from one year to another, depending mainly on the quality of the soil and changing environmental conditions (such as drought, heavy rains, etc.). Another issue is that coefficients are assumed equal for both exported grains and grains for domestic consumption, although they can differ as variety of grains may not be the same for exports and domestic consumption.

72 Data from BACI International Trade database can be downloaded from: http://www.cepii.fr/CEPII/en/bdd_modele/presentation.asp?id=1

73 This represents between $25 \%$ and $90 \%$ of total manure according to the types of manure and national farm practices. 


\section{Estimation procedure of nutrient balance for a given grain}

The total nutrient balance for a given grain is calculated as follows:

Nutrient balance

$$
\begin{aligned}
& =\text { Fertilisers }+ \text { Manure }+ \text { Atmospheric Deposition } \\
& + \text { Nitrogen Fixation }+ \text { Seeds }- \text { Crops }
\end{aligned}
$$

Where variables are defined as follows:

- Fertilisers: Data on the consumption of inorganic fertilisers by country and by crop are provided by the International Fertilizer Association (IFA).

- Manure: The input of nutrients by livestock manure is calculated as the nutrient content of manure applied to crops. Estimations on countries' total manure production are provided by the raw database of the OECD agri-environmental indicators ; the share of managed manure (i.e. applied on crops) is estimated using the FAO-UN and OECD models ${ }^{74}$; the distribution of manure per crop is assumed to be proportional to harvested areas (except for soybeans, on which no manure was spread). The share of managed manure is similar in all European countries, as the EU is considered as a single area in the reference model.

- Atmospheric deposition: The atmospheric deposition of nutrients is estimated using coefficients provided by the raw database of the OECD agri-environmental indicators and Eurostat/OECD (2013) measuring the nutrient deposit per hectare. The deposition per hectare is assumed to be similar for all crops.

- Nitrogen fixation: ${ }^{75}$ The nitrogen fixation by soybeans is estimated using coefficients provided by the raw database of the OECD agri-environmental indicators and Eurostat/OECD (2013) measuring nutrient fixation per hectare of harvested soybeans.

- Seeds: The nutrient input by seeds is estimated using coefficients provided by the raw database of the OECD agri-environmental indicators and Eurostat/OECD (2013) measuring the nutrient content of seeds for each type of crop (per tonne of seeds used or per area harvested crop, according to the availability of the data).

- Crops: The nutrient output by harvested crop is estimated using coefficients provided by the raw database of the OECD agri-environmental indicators and Eurostat/OECD (2013) measuring the nutrient content of each type of crop (per tonne of harvested crop).

74 GLEAM (the UN-FAO Global Livestock Environmental Assessment Model) and the Policy Evaluation Model (OECD). See http://www.fao.org/gleam/fr/ and http://www.fao.org/gleam/fr/.

75 Note that paddy denitrification, which consists in the microbial conversion in paddies of nitrate (NO3-) into atmospheric nitrogen, is not included in our estimate, due to the small amount of available data for each country. 
Table A.9. List of countries covered by the indicator

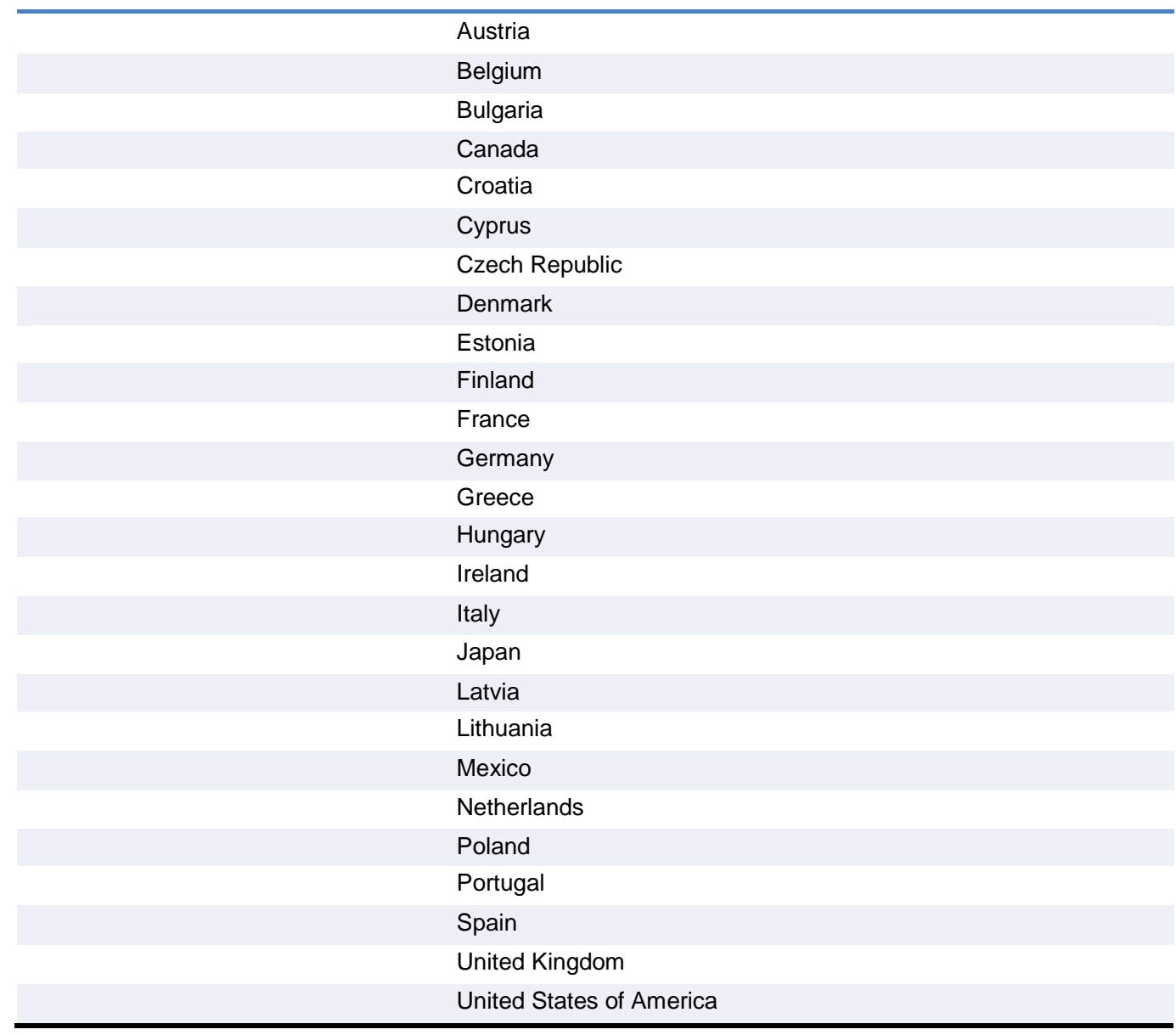

1. Note by Turkey: The information in this document with reference to "Cyprus" relates to the southern part of the Island. There is no single authority representing both Turkish and Greek Cypriot people on the Island. Turkey recognises the Turkish Republic of Northern Cyprus (TRNC). Until a lasting and equitable solution is found within the context of the United Nations, Turkey shall preserve its position concerning the "Cyprus" issue.

2. Note by all the European Union Member States of the OECD and the European Union: The Republic of Cyprus is recognised by all members of the United Nations with the exception of Turkey. The information in this document relates to the area under the effective control of the Government of the Republic of Cyprus. 